\title{
Task 57 - Preparation and Combustion of Coal-Water Fuel \\ Task 57 - Preparation and Combustion of Coal-Water Fuel
from the Sin Pun Coal Deposit, Southern Thailand
}

\section{R}

RECEIVE

Alli 12 1997 082

\section{Topical Report}

May 1997

Work Performed Under Contract No.: DE-FC21-93MC30098

For

U.S. Department of Energy

Office of Fossil Energy

Federal Energy Technology Center

Morgantown Site

P.O. Box 880

Morgantown, West Virginia 26507-0880

DSTAHEUTION OF THIS DOCUNENT IS UNLWMTED

By

Energy \& Environmental Research Center

University of North Dakota

15 North 23rd Street

P.O. Box 9018

Grand Forks, North Dakota 58202-9018 


\section{Disclaimer}

This report was prepared as an account of work sponsored by an agency of the United States Government. Neither the United States Government nor any agency thereof, nor any of their employees, makes any warranty, express or implied, or assumes any legal liability or responsibility for the accuracy, completeness, or usefulness of any information, apparatus, product, or process disclosed, or represents that its use would not infringe privately owned rights. Reference herein to any specific commercial product, process, or service by trade name, trademark, manufacturer, or otherwise does not necessarily constitute or imply its endorsement, recommendation, or favoring by the United States Government or any agency thereof. The views and opinions of authors expressed herein do not necessarily state or reflect those of the United States Government or any agency thereof. 


\section{DISCLAIMER}

Portions of this document may be illegible electronic image products. Images are produced from the best available original document. 


\section{Preparation and Combustion of Coal-Water Fuel from the Sin Pun Coal Deposit, Southern Thailand}

Coal-Water Fuels
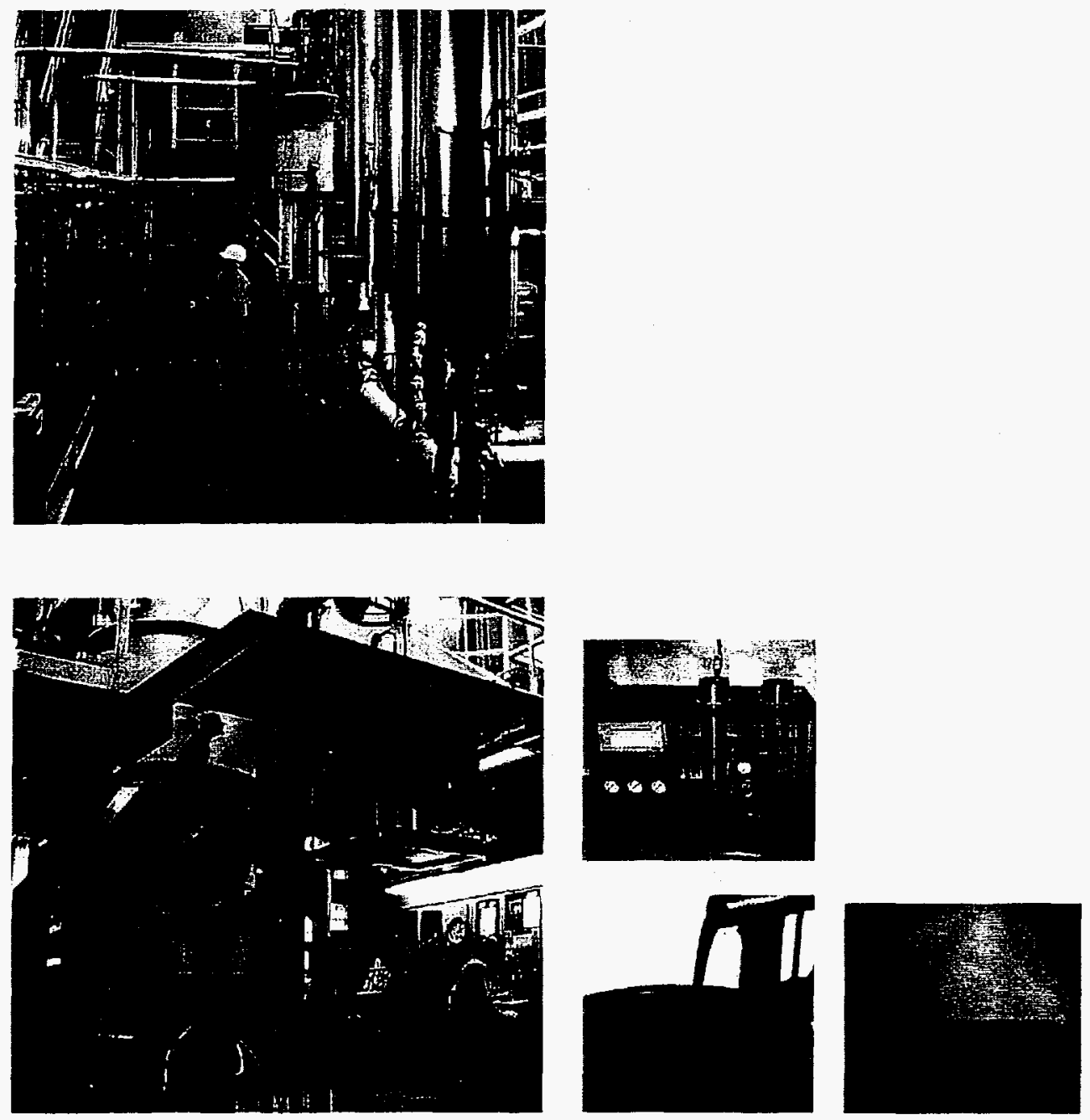


\section{TABLE OF CONTENTS}

LIST OF FIGURES $\ldots \ldots \ldots \ldots \ldots \ldots \ldots \ldots \ldots \ldots \ldots \ldots \ldots \ldots \ldots \ldots \ldots$

LIST OF TABLES $\ldots \ldots \ldots \ldots \ldots \ldots \ldots \ldots \ldots \ldots \ldots \ldots \ldots \ldots \ldots \ldots \ldots \ldots$

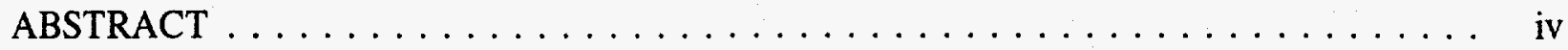

EXECUTIVE SUMMARY $\ldots \ldots \ldots \ldots \ldots \ldots \ldots \ldots \ldots \ldots$

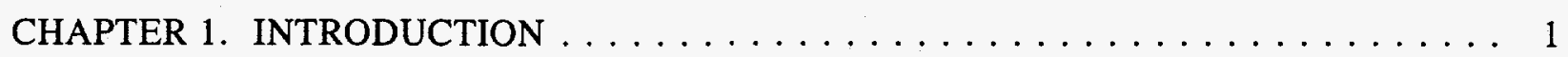

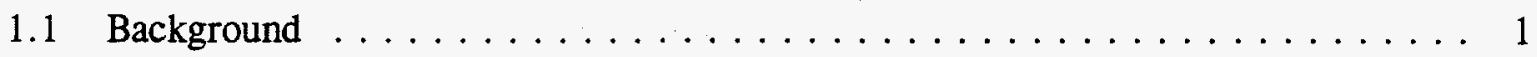

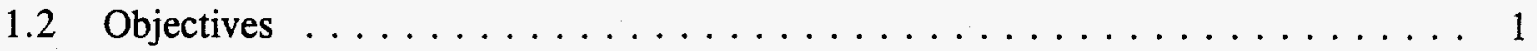

CHAPTER 2. EXPERIMENTAL PROCEDURES AND RESULTS $\ldots \ldots \ldots \ldots \ldots \ldots 2$

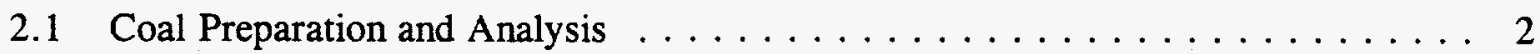

2.2 Bench-Scale Hot-Water Drying $\ldots \ldots \ldots \ldots \ldots \ldots \ldots \ldots \ldots \ldots$

2.3 Pilot-Scale Hot-Water Drying $\ldots \ldots \ldots \ldots \ldots \ldots \ldots \ldots \ldots \ldots$

Production Testing and CWF Preparation $\ldots \ldots \ldots \ldots \ldots \ldots \ldots \ldots \ldots$

2.4 CWF Combustion and Emission Testing $\ldots \ldots \ldots \ldots \ldots \ldots \ldots \ldots \ldots$

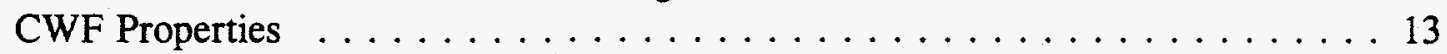

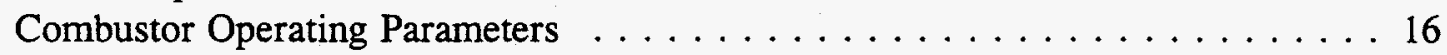

Summary of Ash Results . . . . . . . . . . . . . . . . . . . 19

Stack Emissions and ESP Performance $\ldots \ldots \ldots \ldots \ldots \ldots \ldots \ldots \ldots$

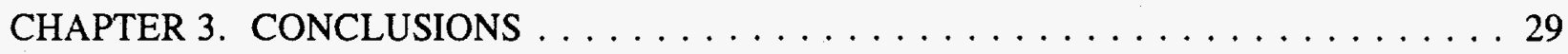

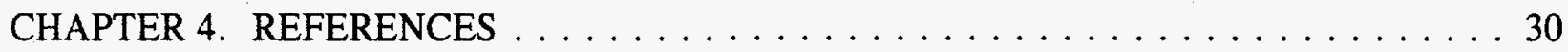

ANALYTIC EQUIPMENT AND PROCEDURES $\ldots \ldots \ldots \ldots \ldots \ldots$ Appendix A

DESCRIPTION OF THE COMBUSTION TEST FACILITY (CTF) AND

EXPERIMENTAL PROCEDURES FOR COAL-WATER FUEL COMBUSTION . . Appendix B

DATASHEETS, OPERATOR'S LOG, AND CIRCULAR CHARTS $\ldots \ldots \ldots$ Appendix C 


\section{LIST OF FIGURES}

1 Schematic diagram of autoclave hot-water drying system $\ldots \ldots \ldots \ldots \ldots$

2 Rheological analysis for raw and HWD coal samples $\ldots \ldots \ldots \ldots \ldots \ldots$

3 Multigram coal extraction system $\ldots \ldots \ldots \ldots \ldots \ldots \ldots \ldots$

4 EERC 7.5-tpd hot-water drying process development unit $\ldots \ldots \ldots \ldots$

5 Rheological analysis for pilot-scale HWD coal samples . . . . . . . . . . . . . 12

6 Coal analysis - viscosity PHOEBE results $\ldots \ldots \ldots \ldots \ldots \ldots$

7 Coal analysis - liquid-phase PHOEBE results $\ldots \ldots \ldots \ldots$

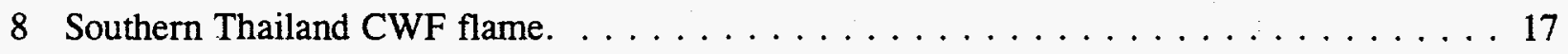

9 Probe bank duct ash deposits . . . . . . . . . . . . . . . . . . 19

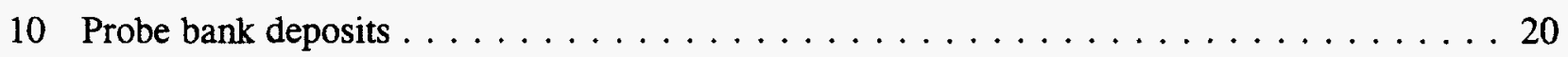

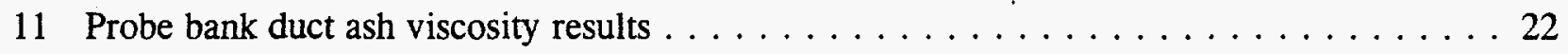

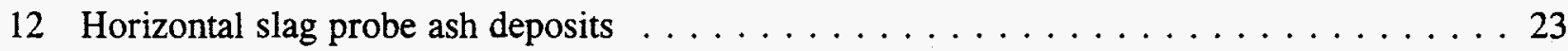

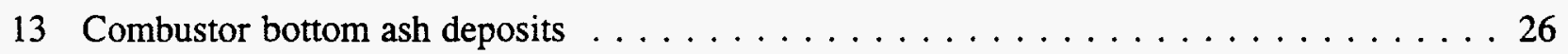

14 Inlet ESP multicyclone particle-size distribution $\ldots \ldots \ldots \ldots \ldots \ldots$

15 ESP collection hopper ash Sample No. 1 particle-size distribution . . . . . . . . . . 28

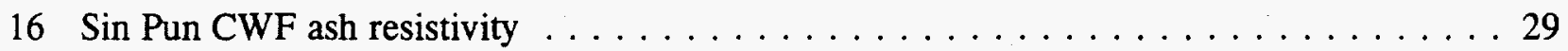

\section{LIST OF TABLES}

1 Particle-Size Distribution Analysis for $\operatorname{Sin}$ Pun Coal $\ldots \ldots \ldots \ldots \ldots \ldots$

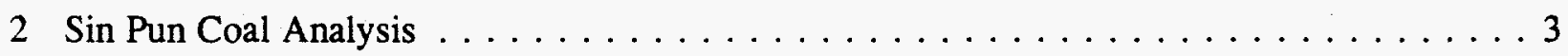

3 Sulfur Forms Analysis for $\operatorname{Sin}$ Pun Coal $\ldots \ldots \ldots \ldots \ldots \ldots$

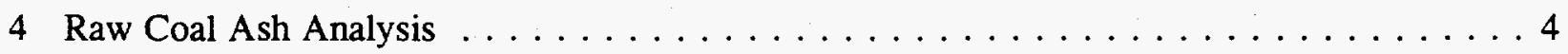




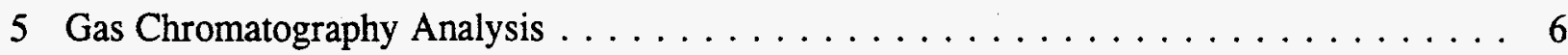

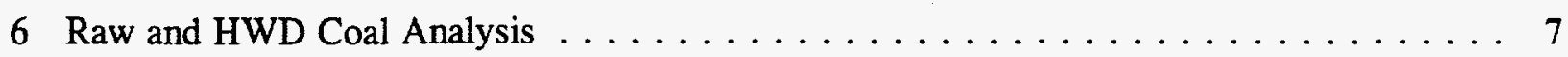

7 Pilot-Scale HWD Sin Pun Lignite Analysis $\ldots \ldots \ldots \ldots \ldots \ldots \ldots \ldots$

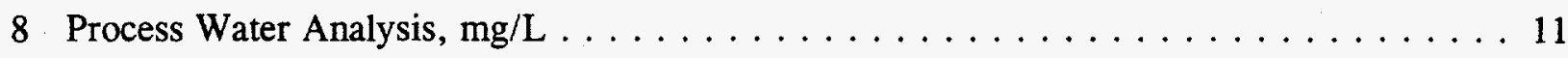

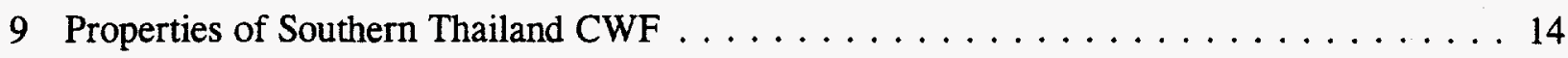

10 Summary of Combustor Operating Parameters - Test Averages $\ldots \ldots \ldots \ldots$

11 SEMPC and XRF Analyses of Probe Bank Duct Deposits . . . . . . . . . 20

12 Results of XRD Analysis - Probe Bank Duct Sintered, Probe Bank,

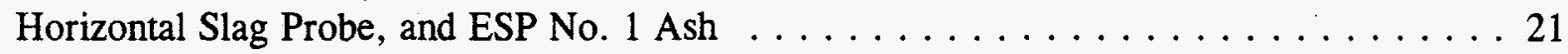

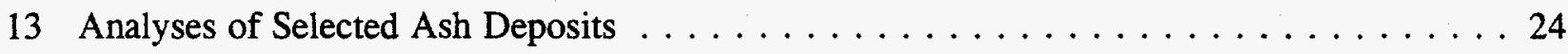

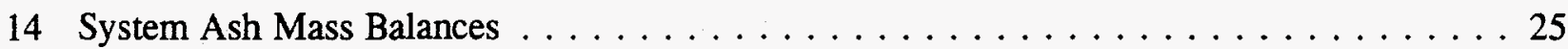

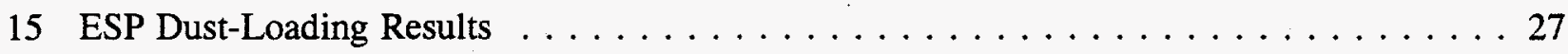

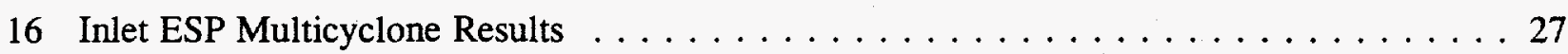




\title{
PREPARATION AND COMBUSTION OF COAL-WATER FUEL FROM THE SIN PUN COAL DEPOSIT, SOUTHERN THAILAND
}

\begin{abstract}
In response to an inquiry by the Department of Mineral Resources in Thailand, the Energy \& Environmental Research Center (EERC) prepared a program to assess the responsiveness of Sin Pun lignite to the temperature and pressure conditions of hot-water drying. The results indicate that drying made several improvements in the coal, notably increases in heating value and carbon content and reductions in equilibrium moisture and oxygen content. The equilibrium moisture content decreased from $27 \mathrm{wt} \%$ for the raw coal to about $15 \mathrm{wt} \%$ for the hot-water-dried (HWD) coals. The energy density for a pumpable coal-water fuel (CWF) indicates an increase from 4500 to $6100 \mathrm{Btu} / \mathrm{lb}$ by hot-water drying. Approximately $650 \mathrm{lb}$ of HWD Sin Pun CWF were fired in the EERC's combustion test facility. The fuel burned extremely well, with no feed problems noted during the course of the test. Fouling and slagging deposits each indicated a very low rate of ash deposition, with only a dusty layer formed on the cooled metal surfaces. The combustor was operated at between $20 \%$ and $25 \%$ excess air, resulting in a flue gas $\mathrm{SO}_{2}$ concentration averaging approximately 6500 parts per million.
\end{abstract}




\section{PREPARATION AND COMBUSTION OF COAL-WATER FUEL FROM THE SIN PUN COAL DEPOSIT, SOUTHERN THAILAND}

\section{EXECUTIVE SUMMARY}

In Thailand, coal is the major source for both power and nonpower usages. Over the past 10 years, the Department of Mineral Resources (DMR) in Thailand has been evaluating the ability of the country's coal reserves to meet its increasing utility and industrial energy needs. DMR discovered over 750 million tons of measured coal and subbituminous reserves. Most of the reserves are the subject of additional exploration and development plans, which include applying clean coal technologies (i.e., coal preparation and beneficiation techniques) to reduce the impact of coal use on the environment.

The Energy \& Environmental Research Center (EERC), which has for years been investigating the conversion of coal to energy-dense liquid fuels, was identified as a leading candidate to perform the development program. In response to the inquiry, the EERC prepared a four-task program to assess the responsiveness of the Sin Pun lignite to the temperature and pressure conditions of hot-water drying. The treated material was to be slurried in water and combusted in the EERC's combustion test facility (CTF). The remaining activity focused on Thai personnel training at the EERC in the area of clean coal technologies.

Approximately $400 \mathrm{~kg}$ of Sin Pun lignite was received at the EERC for testing. The lignite had a moisture-free sulfur content near $10 \mathrm{wt} \%$, with over $95 \mathrm{wt} \%$ organic sulfur. HWD tests were conducted at $300^{\circ}$ and $325^{\circ} \mathrm{C}$ using a bench-scale system. The coal-water fuel (CWF) produced from hot-water drying indicated a $10 \mathrm{wt} \%$ increase in attainable solids. Process gas and water analysis indicated that a portion of the coal's sulfur content was released during hot-water drying. In an effort to further reduce sulfur, hot-water drying tests were conducted at higher temperatures and pressures. The results indicated that over $50 \%$ of the sulfur may be extracted from the coal prior to combustion. Sin Pun ash chemistry does not initially appear to create a problem when the coal is combusted in boiler systems; however, regular sootblowing should be performed to reduce the chance of excessive sintering. Fluid-bed combustion was identified as a good technology to utilize the high-sulfur Sin Pun coal without creating an emission problem.

Pilot-scale hot-water drying tests were performed at $300^{\circ}$ and $325^{\circ} \mathrm{C}$. Slurry feed rates for the $300^{\circ}$ and $325^{\circ} \mathrm{C}$ hot-water drying tests were approximately $500 \mathrm{lb} / \mathrm{hr}$. The overall solids recoveries for the two tests were approximately $93 \mathrm{wt} \%$. The results indicate that hot-water drying made several improvements to the Sin Pun coal, including an equilibrium moisture reduction of $40 \%$, sulfur reduction of $10 \%$, and a modest increase in heating value. Comparison of energy density (slurry basis) for fuels with similar viscosity showed an increase from 4500 to $6070 \mathrm{Btu} / \mathrm{lb}$ at $300^{\circ} \mathrm{C}$ and $6090 \mathrm{Btu} / \mathrm{lb}$ at $325^{\circ} \mathrm{C}$. Approximately $360 \mathrm{~kg}(800 \mathrm{lb})$ of CWF with a target viscosity of nominally $500 \mathrm{cP}$ was prepared for combustion testing.

The fuel burned extremely well, with no feed problems noted during the course of the test. Fouling and slagging deposits each indicated a very low rate of ash deposition, with only a dusty layer formed on the cooled metal surfaces. The combustor was operated between $20 \%$ and $25 \%$ excess air, resulting in a flue gas $\mathrm{SO}_{2}$ concentration averaging approximately $6500 \mathrm{ppm}$. This level 
indicates between $20 \%$ and $25 \%$ of the input sulfur content was captured by alkaline species, such as calcium, in the fly ash.

Personnel from Thailand's DMR arrived in Grand Forks and completed interactive training by observing bench- and pilot-scale hot-water drying demonstrations, CWF preparation and evaluation, and CWF combustion. 


\section{PREPARATION AND COMBUSTION OF COAL-WATER FUEL FROM THE SIN PUN COAL DEPOSIT, SOUTHERN THAILAND}

\section{CHAPTER 1. INTRODUCTION}

\subsection{Background}

Low-rank coals (LRCs), which include lignite and subbituminous coals, constitute almost half of the vast reserves of coal that exist worldwide. Typically, deposits of these LRCs occur in thick seams with relatively thin cover; consequently, mining operations are generally inexpensive. Further, although at the bottom end of the quality range in coal classification, they are usually more homogeneous in their as-mined condition than high-rank coals. This feature is especially characteristic of lignite. However, despite their excellent combustion characteristics and other attractive properties, utilization of lignite and subbituminous coal has, to date, been largely confined to generating electrical power at or close to the mine site. The high moisture content and instability of LRCs have until now prevented their transport to distant coal markets.

The widespread use of LRCs in traditional coal markets is constrained by the following factors:

- High inherent moisture content

- High degree of risk for spontaneous combustion

- Weathering and resultant dust nuisance

- Fouling and slagging problems caused by high sodium content

Although their high inherent moisture content lowers their heating value and thus increases the cost of transportation and handling, the positive features of LRCs, such as their low cost per Btu and excellent combustion characteristics, have, to date, been ignored. No commercial drying process is currently available that can economically produce a conventional, dried bulk coal product that will withstand the rigors of storage, handling, and transportation. Traditional thermal drying methods used to dry bituminous coal are not effective on subbituminous coal and lignite because of the resulting decrepitation of these coals.

This situation encouraged researchers at the Energy \& Environmental Research Center (EERC) to investigate alternative methods for drying such high-moisture coals economically. Their pioneering efforts led to the successful development of a hot-water-drying process for coal slurries at the EERC facility in Grand Forks, North Dakota, the world's largest research and development complex for investigating LRCs. This novel, nonevaporative drying technique is ideally suited for producing a coal-water fuel (CWF). As a consequence, subbituminous coal and lignite have now become more economically attractive for the production of CWF.

\subsection{Objectives}

The specific objectives of the project were as follows:

- To investigate the hot-water drying conditions for the selected southern Thai lignite at the bench and pilot scale

- To evaluate the combustion performance of the hot-water-dried (HWD) Thai lignite slurry 


\section{CHAPTER 2. EXPERIMENTAL PROCEDURES AND RESULTS}

\subsection{Coal Preparation and Analysis}

Approximately $450 \mathrm{~kg}$ of Sin Pun lignite from Southern Thailand was shipped to the EERC. The coal, received as lumps up to $0.25 \mathrm{~m}$ (estimated), was crushed with a roll crusher, producing nominal 4- $\times 0-\mathrm{cm}$ coal and then processed with a roller mill to $6.35 \times 0 \mathrm{~mm}$. Approximately $350 \mathrm{~kg}$ was pulverized for bench- and pilot-scale testing. $100 \mathrm{~kg}$ of "as-received" lignite was stored for future experimentation. Table 1 represents the particle size for the Sin Pun coal sample, which will be used for most of the hot-water drying tests at the EERC. Approximately $50 \mathrm{~kg}$ of coal sample was separated and stored for future work. A representative coal was submitted for proximate, ultimate, heating value, sulfur forms, and $\mathrm{x}$-ray fluorescence analysis and ash fusion determinations. Analytical equipment and methods are presented in Table A-1 (Appendix A).

Table 2 summarizes the coal characteristics of the Sin Pun coal received by the EERC. The coal has a moderate ash content (11.3 wt \% moisture-free [mf]), extremely high sulfur content ( $9.3 \mathrm{wt} \% \mathrm{mf})$, moderate nitrogen content $(1.0 \mathrm{wt} \% \mathrm{mf})$, and as-received moisture content of $20.3 \mathrm{wt} \%$. The as-received heating value was $7650 \mathrm{Btu} / \mathrm{lb}$, which translates to a moisture-free heating value of $9600 \mathrm{Btu} / \mathrm{lb}$.

\section{TABLE 1}

Particle-Size Distribution Analysis for Sin Pun Coal

\begin{tabular}{lc}
\hline & Cumulative wt $\%$ Under Size \\
\cline { 2 - 2 } Particle Size, $\mu \mathrm{m}$ & Pulverized Coal \\
\hline 500 & 100.0 \\
300 & 100.0 \\
150 & 97.9 \\
100 & 92.0 \\
75 & 83.2 \\
50 & 71.4 \\
45 & 58.1 \\
35 & 46.7 \\
10 & 23.1 \\
5 & 9.9 \\
2 & 0.5 \\
Estimated MMD & $40 \mu \mathrm{m}$ \\
\hline Mass mean diameter or average particle size.
\end{tabular}


TABLE 2

Sin Pun Coal Analysis

\begin{tabular}{lrcc}
\hline & As-Received & $\begin{array}{c}\text { Moisture-Free } \\
\text { Raw Coal }\end{array}$ & $\begin{array}{c}\text { Moisture- and } \\
\text { Ash-Free }\end{array}$ \\
\hline Proximate Analysis, wt\% & & & \\
Moisture & 20.3 & - & - \\
$\quad$ Volatile Matter & 42.4 & 53.18 & 59.9 \\
Fixed Carbon & 28.3 & 35.55 & 40.1 \\
Ash & 9.0 & 11.27 & - \\
Ultimate Analysis, wt\% & & & \\
Carbon & 46.3 & 58.14 & 65.5 \\
Hydrogen & 5.7 & 4.36 & 4.9 \\
Nitrogen & 0.8 & 1.04 & 1.2 \\
Sulfur & 7.4 & 9.32 & 10.5 \\
Oxygen & 30.7 & 15.87 & 17.9 \\
Ash & 9.0 & 11.27 & - \\
Heating Value, Btu/lb & 7650 & 9602 & 10,800 \\
\hline
\end{tabular}

The ratio of fixed carbon to volatile matter is used by steam coal users as a barometer to determine whether a coal will burn well in a conventional boiler system. Typically, a ratio of less than 1.3 represents a good steam coal. At higher values, the coal may not completely combust, which leads to unburned fuel and adds carbon to the ash. The calculated fuel ratio for Sin Pun coal is 0.66 , which means the coal is reactive and should burn completely in a boiler; however, it is likely to be prone to spontaneous heating when stockpiled.

Sulfur forms analysis, Table 3, indicated that over $95 \mathrm{wt} \%$ of total sulfur is present as organic sulfur. If the sulfur were in the pyritic form, conventional or advanced physical cleaning procedures could effectively reduce the sulfur content. However, the high organic fraction creates a greater problem. Within the United States, research efforts to reduce organic sulfur have focused on the addition of special chemicals and thermal processes to release the sulfur (1). These techniques and their effectiveness in removing sulfur are coal-specific and would have to be tried with the Sin Pun coal. These tests are considered outside the scope of the existing program. Table 3 reports a higher total sulfur value than Table 2, likely because of differences in laboratory procedures.

Based on ash chemistry, represented in Table 4, problems are not anticipated with fouling and slagging when Sin Pun coal is combusted in a boiler system. The high level of sulfur may, however, contribute to a sintering problem on boiler tubes if regular sootblowing is not performed. 
TABLE 3

Sulfur Forms Analysis for Sin Pun Coal

\begin{tabular}{lc}
\hline Analytical & Dry Basis, wt\% \\
\hline Proximate & \\
Total Sulfur & 10.59 \\
Sulfur Forms & \\
Organic & \\
Pyritic & 9.85 \\
Sulfatic & 0.23 \\
Total Sulfur & 0.51 \\
\hline
\end{tabular}

TABLE 4

Raw Coal Ash Analysis, wt\%

\begin{tabular}{lcc}
\hline Sample Anaiysis & Oxides & Elemental \\
\hline Silica & 34.5 & 27.2 \\
Aluminum & 14.9 & 13.3 \\
Iron & 19.4 & 22.9 \\
Titanium & 0.7 & 0.7 \\
Phosphorus & 0.3 & 0.2 \\
Calcium & 25.7 & 31.0 \\
Magnesium & 4.0 & 4.1 \\
Sodium & 0 & 0 \\
Potassium & 0.4 & 0.6 \\
\hline
\end{tabular}

\subsection{Bench-Scale Hot-Water Drying}

The bench-scale hot-water drying tests with pulverized coal were performed in the EERC's 7.6-liter batch autoclave shown in Figure 1. The bolted-closure autoclave is externally heated and equipped with automatic temperature controllers and a variable-speed magnetically driven stirrer. The autoclave is instrumented to continuously measure and trend pressure plus slurry and vapor temperatures. 


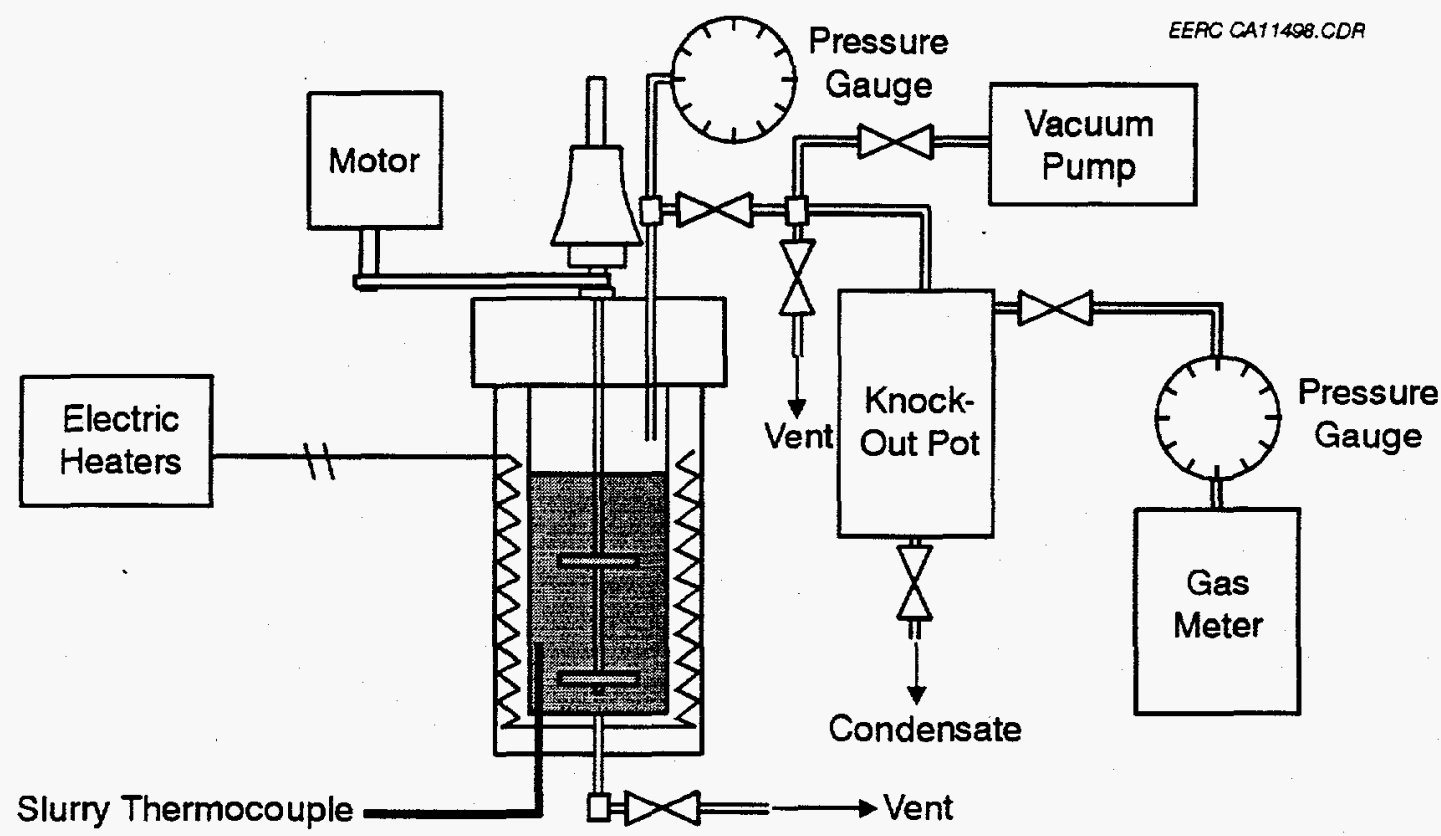

Figure 1. Schematic diagram of autoclave hot-water drying system.

Approximately 3000 grams of a $50 \mathrm{wt} \%$ coal $/ 50 \mathrm{wt} \%$ deionized water feed slurry was used in each hot-water drying test. After feed slurry was charged to the autoclave, residual air was evacuated and the external heaters and stirrer turned on. Heatup to the desired temperature ranged from approximately 2 to $2 \frac{1 / 2}{2}$ hours, after which the slurry and vapor temperatures were allowed to stabilize. After a 15-minute hold time at temperature, the heaters were shut off, and the autoclave and contents were allowed to cool overnight.

Fractions recovered from the autoclave after cooldown included process gas, product slurry, and condensate. The total volume of process gas (noncondensable decomposition products) was measured with a diaphragm meter. Process gas was sampled for off-line analysis. The product slurry was recovered, weighed, and then dewatered via Büchner filtration.

Two autoclave tests were performed at two different treatment temperatures. The HWD solids were then reslurried in water and evaluated for rheological performance. The rheological behavior for the coal-liquid mixture, specifically the apparent viscosity, is determined as a function of shear rate and CWF solids concentrations. Since any change in solids loading of a CWF has a direct effect on the resulting flow behavior, several rheograms throughout the possible solidsloading range were gathered. The analytical equipment and methods are presented in Table A-1 (Appendix A).

Results from the autoclave experiments indicate that the solids recoveries for the $300^{\circ}$ and $325^{\circ} \mathrm{C}$ tests were $96 \%$ and $94 \%$, respectively. The solids losses were mainly due to evolved gases. Table 5 gives the composition of the gas based on the $325^{\circ}$ tests performed using a HewlettPackard 5880a gas chromatograph. The results indicate that about $82 \mathrm{wt} \%$ of the gas evolved as $\mathrm{CO}_{2}$ and $10 \mathrm{wt} \%$ as hydrogen sulfide. This is a high level of hydrogen sulfide and may have to be treated with a sulfur recovery or treatment system such as the Holmes-Stretford process or a scrubber system (2). Process water was weighed and suspended solids determined. Process water 
TABLE 5

Gas Chromatography Analysis

\begin{tabular}{lc}
\hline Description & $325^{\circ} \mathrm{C}$ \\
\hline Gas Concentration, wt $\%$ & \\
Helium & 0.07 \\
Hydrogen & 0.46 \\
Carbon Dioxide & 82.16 \\
Propylene & 0.02 \\
Isobutane & 0.01 \\
Carbonyl Sulfide & 0.01 \\
$n$-Butane & 0.02 \\
Hydrogen Sulfide & 11.20 \\
1-Butene & 0.06 \\
Ethylene & 0.02 \\
Ethane & 0.29 \\
Oxygen/Argon & 0.11 \\
Nitrogen & 3.80 \\
Methane & 1.78 \\
Calculated Btu/scf & \\
Saturated & 98.3 \\
Dry & 100.0 \\
Calculated Specific Gravity & 1.439 \\
Calculated Average Mole Weight & 41.53 \\
\hline
\end{tabular}

did have a distinct odor, indicating the presence of sulfur compounds that were extracted from the coal during the hot-water drying process. A more complete water analysis will be performed on the pilot-scale samples. Details of the instrumentation and techniques performed on the water and gas are in Appendix A.

Table 6 summarizes the proximate, ultimate, and heating value analyses for the raw and HWD samples. The results indicate that hot-water drying made several improvements in the coal, most notably a large reduction in oxygen, which translated into a concentration of fixed carbon and other components. The coal's oxygen content was reduced by over $40 \%$ at $300^{\circ} \mathrm{C}$ and over $60 \%$ at $325^{\circ} \mathrm{C}$, primarily as a result of the decarboxylation and mild pyrolysis experienced during hotwater drying. The moisture-free heating value increased by nearly $15 \%$ as a result of hot-water drying. The moisture-free sulfur content indicates an increase; however, sulfur compounds were released by hot-water drying, as indicated in the gas analysis and by the distinct process water odor.

The rheological profiles in Figure 2 show the effect of hot-water drying temperature on CWF solids concentration and viscosity. The results indicate that hot-water drying definitely improves the solids concentration of the fuel, increasing the attainable solids content by over $10 \mathrm{wt} \%$, which translates to an energy density increase of over $30 \%$. For the HWD fuels, the solids loading at $500 \mathrm{cP}$ is approximately $60 \mathrm{wt} \%$, or $6400 \mathrm{Btu} / \mathrm{lb}$, as a CWF. Only a 1 to $2 \mathrm{wt} \%$ difference in 
TABLE 6

Raw and HWD Coal Analysis (moisture-free)

\begin{tabular}{lrcc}
\hline & Raw Coal & $300^{\circ} \mathrm{C}$ & $325^{\circ} \mathrm{C}$ \\
\hline Proximate Analysis, mf, wt\% & & & \\
Volatile Matter & 53.18 & 46.40 & 44.33 \\
Fixed Carbon & 35.55 & 41.61 & 43.08 \\
Ash & 11.27 & 11.99 & 12.59 \\
Ultimate Analysis, mf, wt\% & & & \\
Carbon & 58.14 & 62.86 & 65.82 \\
Hydrogen & 4.36 & 4.39 & 4.43 \\
Nitrogen & 1.04 & 1.25 & 1.20 \\
Sulfur & 9.32 & 10.09 & 9.93 \\
Oxygen & 15.87 & 9.42 & 6.03 \\
Ash & 11.27 & 11.99 & 12.59 \\
Heating Value, Btu/lb & 9602 & 10,727 & 11,025 \\
\hline
\end{tabular}

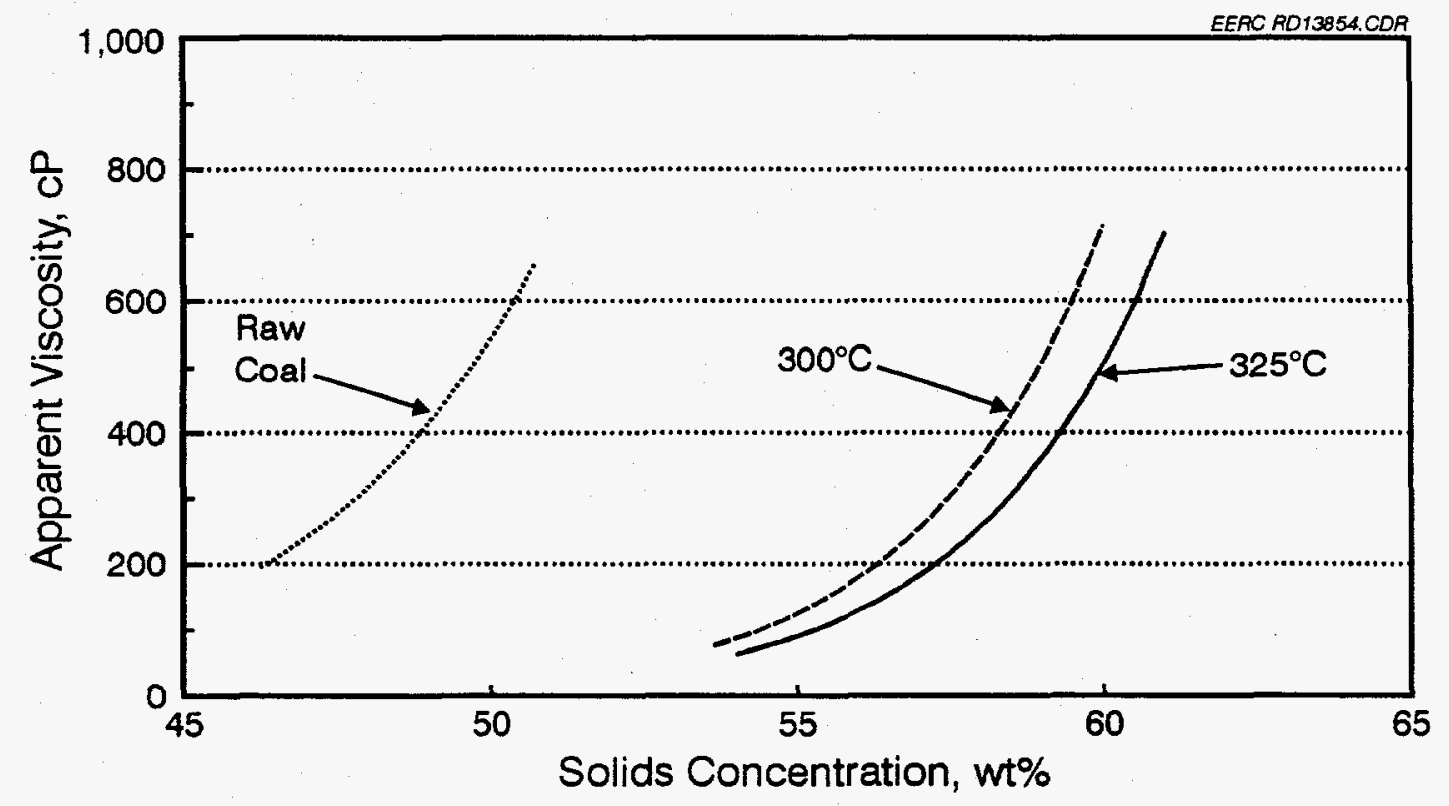

Determined at $100 \mathrm{~Hz}$ decreasing shear rate.

Figure 2. Rheological analysis for raw and HWD coal samples (temperature effect). 
attainable solids concentration was observed between $300^{\circ}$ and $325^{\circ} \mathrm{C}$. Any difference is attributed to decarboxylation, a greater amount occurring at the higher temperature. A reduced hot-water drying temperature translates to lower system pressure, which is critical to the economic viability of a commercial process.

Because of the high sulfur content, which is mainly organic sulfur, EERC personnel processed the coal with an advanced hydrothermal technology being developed at the EERC at temperatures between $250^{\circ}$ and $450^{\circ} \mathrm{C}$. The multigram unit, a $40-\mathrm{cm}^{3}$ reactor, is capable of hydrothermally treating 10-20 $\mathrm{g}$ at the elevated temperatures and pressures. Figure 3 illustrates the bench-scale extraction system. A pneumatically operated pump capable of continuously pumping water at 10 to $300 \mathrm{~cm}^{3} / \mathrm{min}$ through the fixed bed of coal was used.

For the Sin Pun coal, extractions were conducted with $6.35-\times 0.5-\mathrm{mm}$ coal and at a particle size similar to autoclave testing (average $40 \mu \mathrm{m}$ ). A 10- to 20-g weighed sample of coal was placed in the $40-\mathrm{cm}^{3}$ reactor. The frits were put in place, the end caps of the reactor were tightened, and the reactor was then placed in the tube furnace. Fluid inlet and outlet tubing was attached, and all couplings were checked to be certain they were secure. The preheater and reactor heater were heated at maximum output for $5 \mathrm{~min}$ without fluid flow. When the target temperature was reached, the pump was turned on and the system pressure was brought to target pressure and set to flow at approximately $30 \mathrm{~mL} / \mathrm{min}$.

The temperature of the flowing water was monitored at the reactor inlet and outlet and was held at the desired temperature by adjusting water flow through the system. After a selected residence time at extraction temperature and pressure, the system was cooled and depressurized and the extracted coal was taken from the reactor. Extraction temperatures were $400^{\circ} \mathrm{C}$ for the coarse coal fraction and $380^{\circ} \mathrm{C}$ for the fine coal. The results from this testing indicated an approximately $50 \%$ reduction in total sulfur and solid recoveries of $40 \%-50 \%$.

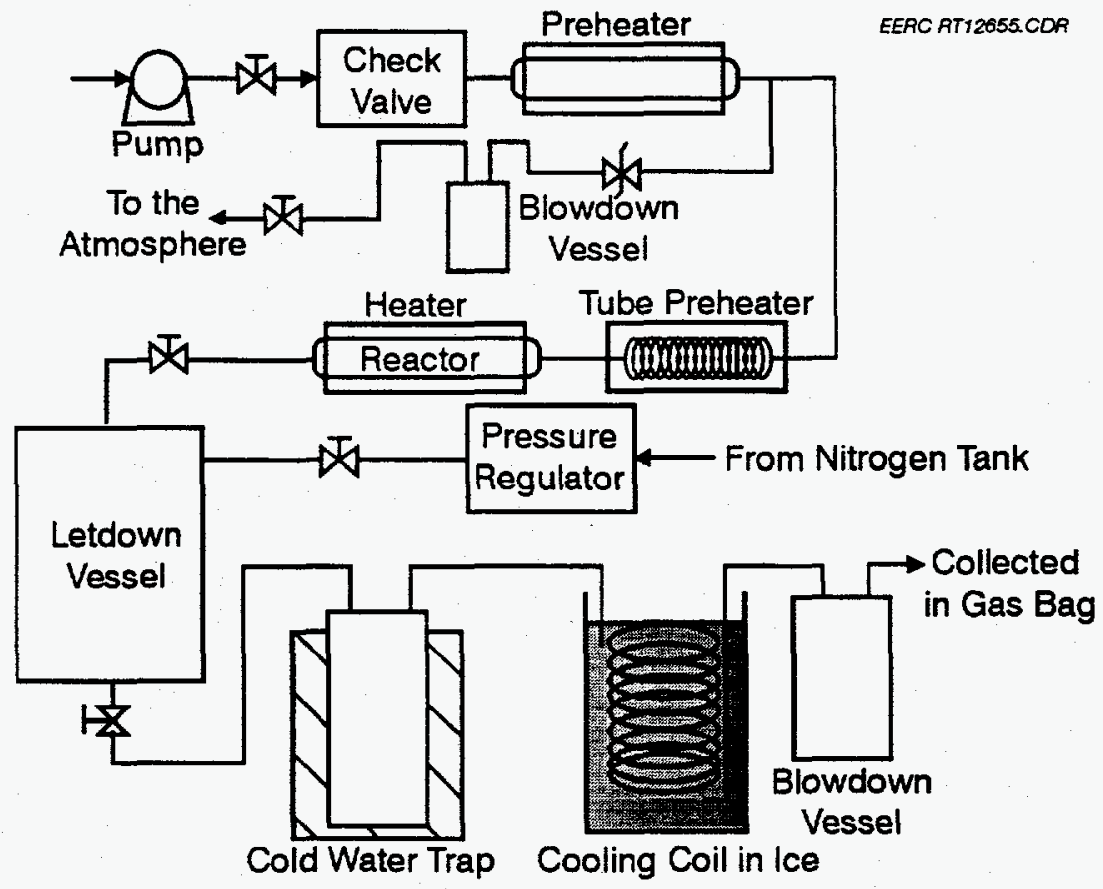

Figure 3. Multigram coal extraction system. 
Coals that are typically as high in sulfur as Sin Pun lignite are combusted predominantly in fluid-bed systems where limestone or coal ash capture the sulfur. In 1992, the EERC and others completed a feasibility study for the Electricity Generating Authority of Thailand (EGAT) that examined the integration of fluid-bed technology with pulverized coal combustion at Mae Moh in northern Thailand (3). Extensive pilot-scale tests at the EERC indicated that the high-sulfur-content lignite can be fired with little or no concern for combustor/furnace slagging problems. The tests also demonstrated the effectiveness of fluid-bed technology in controlling emissions while achieving effective carbon burnout at nominal excess air levels.

Another potential use for high-sulfur coals may be as activated carbons. Sulfur-impregnated carbons are currently being used in the United States and elsewhere to capture gaseous mercury in flue gas from waste incinerators. More testing (outside the scope of this project) would be needed to confirm whether these technologies and others are indeed technically and economically feasible with the Sin Pun lignite.

\subsection{Pilot-Scale Hot-Water Drying}

Sin Pun lignite was processed using the 7.5-tpd hot-water drying process development unit shown in Figure 4. Briefly, the system consists of the following major unit operations: slurry preparation, pumping, preheat, reaction, pressure letdown, product recovery, and HWD coal dewatering.

The coal to be processed is first pulverized with a hammer mill and then slurried to the desired coal-to-water ratio. A high-pressure pump, capable of pumping highly viscous feed slurries up to $2500 \mathrm{mPa}$-s is used to deliver the slurry to the preheat section at the desired system operating pressure. Slurry flow rate is controlled using a variable-speed motor.

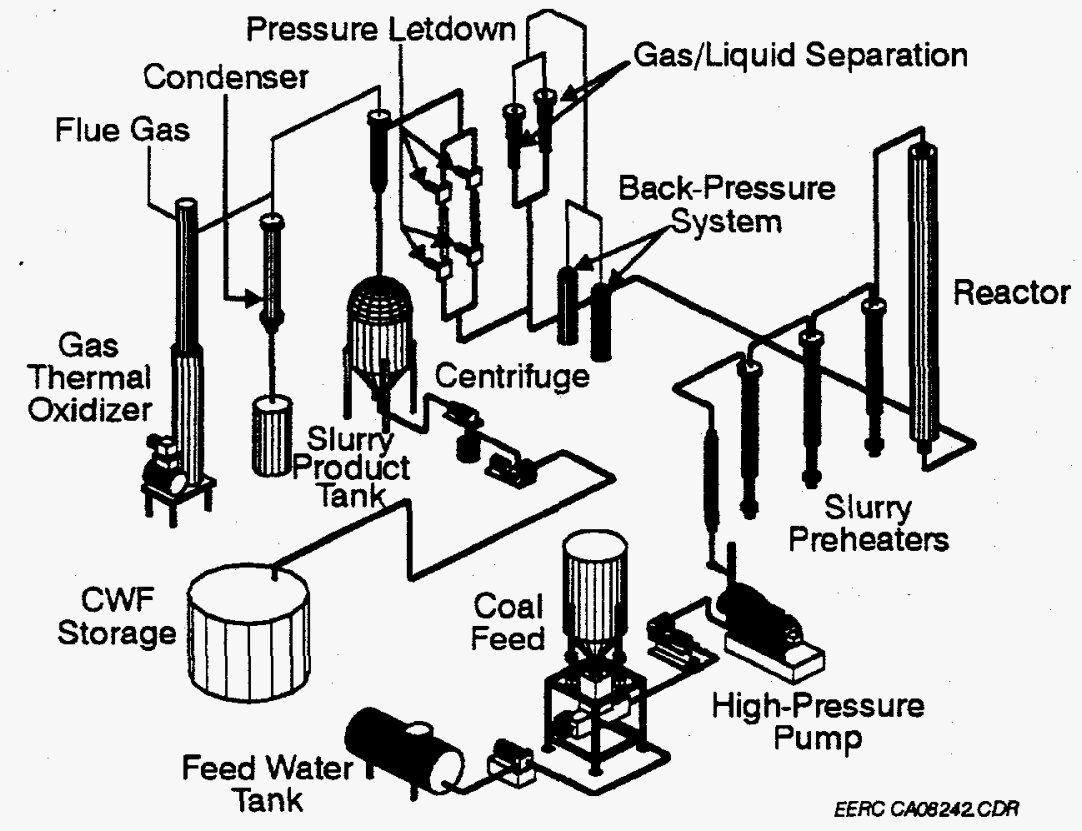

Figure 4. EERC 7.5-tpd hot-water drying process development unit. 
A series of four heat exchangers is used to preheat the slurry to the desired processing temperature. A double-pipe steam heat exchanger first heats the slurry up to $80^{\circ} \mathrm{C}$, whereafter the slurry is heated in a series of three condensing Dowtherm vapor-liquid heat exchangers. The nominal ratings of the electric immersion heaters are 22,22 , and $30 \mathrm{~kW}$, respectively.

The slurry, after exiting the fourth preheater at the desired processing temperature, is then directed to a series of two downflow reactors. The process piping is configured to allow using a single reactor to attain a residence time of 7 minutes or both reactors to attain a residence time of 15 minutes. Each reactor is equipped with four $2-\mathrm{kW}$ externally mounted heaters to achieve isothermal temperature control.

After processing at the desired temperature and residence time, the coal slurry is throttled through pressure-reducing valves with a resultant flashing of steam and process gas. The gas-water vapor stream is cyclonically separated from the concentrated hot-water-dried coal slurry. The gas-water vapor stream is drawn through a multipass water-cooled condenser, whereafter the noncondensable process gas phase is sent to a natural gas-fired incinerator fired at $800^{\circ} \mathrm{C}$. Condensate is collected for possible recycle. The product slurry is dewatered using a recessed filter press, producing damp filter cake and filtrate.

\section{Production Testing and CWF Preparation}

Pilot-scale test parameters were based upon the results from bench-scale evaluations, discussed earlier in this report under Task 1 . Tests were completed at two temperatures $\left(300^{\circ}\right.$ and $325^{\circ} \mathrm{C}$ ). The Sin Pun lignite, pulverized to $250-\mu \mathrm{m}(60$-mesh) top size and an average size of $30 \mu \mathrm{m}$, was processed at a $45 \% / 55 \%$ coal-to-water ratio.

The weights of feed slurry, product slurry, condensate, filter cake, and filtrate were collected at each test condition to facilitate calculation of overall material and solids recoveries.

A representative filter cake sample was obtained at each test condition for analysis. Gas chromatographic analyses were performed on select samples of process gas.

Rheological evaluations were performed by admixing the damp cake from hot-water drying with water to produce several different fuel concentrations. The rheological behavior of the slurry fuel, including variation of apparent viscosity as a function of shear rate, was determined for three or four solids concentrations using a Haake RV 100 viscometer.

Slurry feed rate for the pilot-scale testing was $500 \mathrm{lb} / \mathrm{hr}$, which equates to approximately 20 minutes at temperature and pressure. The overall solids recoveries for the two tests were approximately $93 \mathrm{wt} \%$. These values compare favorably with bench-scale hot-water drying recovery values.

Table 7 summarizes the analysis results for the pilot-scale HWD samples; the raw coal is included for comparison. The results indicate that hot-water drying made several improvements to the Sin Pun coal, including an equilibrium moisture reduction of $40 \%$, sulfur reduction of $10 \%$, and a modest increase in heating value. The increases in heating value appeared to be consistent with the effect of increasing the processing temperature.

Process gas samples obtained during processing were nearly equivalent in composition. Carbon dioxide was the primary component at $>86 \mathrm{vol} \%$, with hydrogen sulfide at $>11$ vol\% and 
smaller concentrations of methane $(\sim 0.8 \mathrm{vol} \%)$ and hydrogen $(\sim 0.1 \mathrm{vol} \%)$. The quantity of process gas was not measured. Process water analyses are presented in Table 8 for the pilot-scale tests. For more information on process water and process gas, consult Appendix A.

\section{TABLE 7}

Pilot-Scale HWD Sin Pun Lignite Analysis

\begin{tabular}{lrrr}
\hline & Raw & $300^{\circ} \mathrm{C}$ & $325^{\circ} \mathrm{C}$ \\
\cline { 3 - 4 } Equilibrium Moisture, wt\% & 25.17 & 17.86 & 14.21 \\
\cline { 1 - 1 } $\begin{array}{l}\text { Proximate Analysis, wt\% } \\
\text { (moisture-free) }\end{array}$ & & & \\
$\quad$ Volatile Matter & 52.78 & 47.32 & 46.16 \\
Fixed Carbon & 35.97 & 42.15 & 41.87 \\
Ash & 11.25 & 10.53 & 11.97 \\
Ultimate Analysis, wt\% & & & \\
(moisture-free) & & & \\
Hydrogen & 4.88 & 4.39 & 4.32 \\
Carbon & 57.23 & 62.28 & 62.53 \\
Nitrogen & 1.00 & 1.10 & 1.17 \\
Sulfur & 9.79 & 8.92 & 8.61 \\
Oxygen & 15.85 & 12.78 & 11.40 \\
Ash & 11.25 & 10.53 & 11.97 \\
Heating Value, Btu/lb & 9470 & 10,650 & 10,680 \\
\hline
\end{tabular}

TABLE 8

Process Water Analysis, mg/L $300^{\circ} \mathrm{C}$

$325^{\circ} \mathrm{C}$

\begin{tabular}{lcccc} 
Analysis & Filtrate & Condensate & Filtrate & Condensate \\
\hline BOD $^{1}$ & 4000 & 2400 & 4600 & 3280 \\
$\mathrm{COD}^{2}$ & 6300 & 3860 & 7500 & 6200 \\
Total Suspended Solids & 277 & 51 & 255 & 130 \\
Total Dissolved Solids & 8820 & 92 & 9250 & 112 \\
Total Organic Carbon & 2500 & 1500 & 2950 & 2050 \\
Total Carbon & 2530 & 1500 & 3300 & 2140 \\
Sulfate & 3890 & 8 & 3090 & 13
\end{tabular}

${ }^{1}$ Biological oxygen demand.

${ }^{2}$ Chemical oxygen demand. 
The rheological profiles in Figure 5 indicate the effect of temperature $\left(300^{\circ}\right.$ and $325^{\circ} \mathrm{C}$, respectively) on CWF solids concentration and viscosity. In comparison to the bench-scale rheology there was not a 1-2 wt\% increase in solids concentration when the processing temperature was increased from $300^{\circ}$ to $325^{\circ} \mathrm{C}$. Similar to bench-scale results, pilot-scale processing did significantly improve the solids content (and energy density) of the Sin Pun lignite. Comparison of energy density (slurry basis), for fuels with a viscosity of $500 \mathrm{cP}$, showed an increase from 4500 to $6070 \mathrm{Btu} / \mathrm{lb}$ at $300^{\circ} \mathrm{C}$ and $6090 \mathrm{Btu} / \mathrm{lb}$ at $325^{\circ} \mathrm{C}$.

HWD coal produced in the pilot-scale production run was formulated into CWF for subsequent combustion testing. The two fuels were combined in order to produce enough fuel for combustion testing. Approximately $360 \mathrm{~kg}(800 \mathrm{lb})$ of CWF was prepared with a target viscosity of nominally $500 \mathrm{cP}$. The CWF had a solids concentration of $57.2 \mathrm{wt} \%$ and an estimated heating value of $6100 \mathrm{Btu} / \mathrm{lb}$. The combined material viscosity curve is included in Figure 5, and it indicates a slight increase in comparison to the two processing conditions. The single point on the combined fuel curve is for the actual fuel that was burned in the combustion test.

Relative to bench-scale hot-water drying, pilot-scale testing produced fuels 1 to $2 \mathrm{wt} \%$ lower in solids loading. This can be explained by the differences in residence time achieved during batchand continuous-scale processing. During pilot-scale testing, operating temperature is reached after approximately $2 \mathrm{~min}$., while bench-scale heatup takes approximately $2 \mathrm{hr}$. Bench-scale fuel performance results are usually better than pilot-scale results because of the extended time in which the coal is exposed to temperatures above $200^{\circ} \mathrm{C}$.

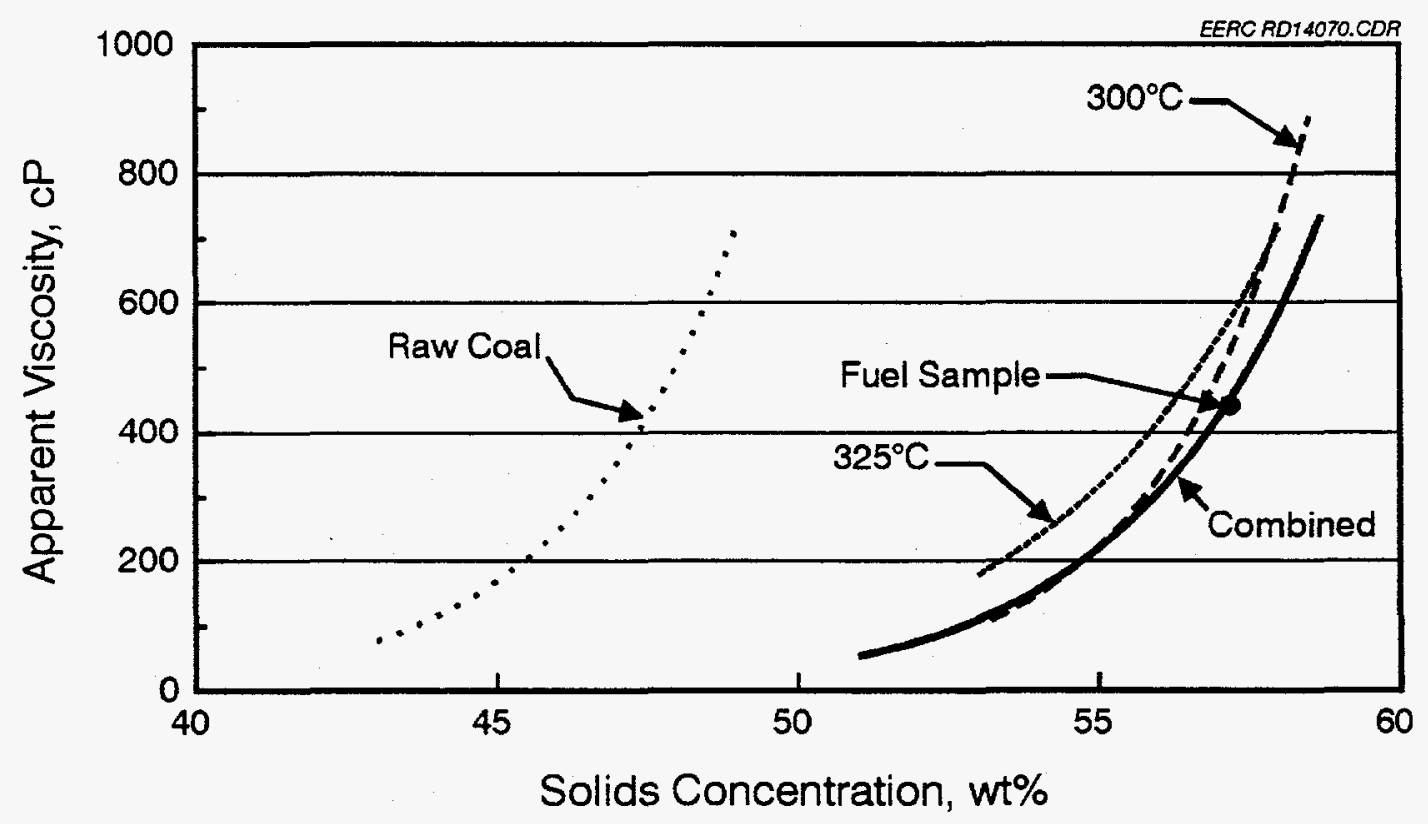

Determined at $100 \mathrm{~Hz}$ decreasing shear rate

Figure 5. Rheological analysis for pilot-scale HWD coal samples. 


\subsection{CWF Combustion and Emission Testing}

A single test was conducted to evaluate combustion property enhancements resulting from the upgrading of a selected lignite from the Sin Pun coal deposit in southern Thailand using the HWD technique. The CWF product from the process was fired in the EERC's combustion pilot plant, utilizing the combustion test facility (CTF). The CTF is a refractory-lined, bottom-fired furnace sized to achieve firing rates between 550,000 and $750,000 \mathrm{Btu} / \mathrm{hr}$. The CTF, originally built to test pulverized coals, has been enhanced to expand its capabilities to test other fuels such as CWFs and refuse-derived fuels. The balanced-draft unit is fully instrumented to characterize combustion conditions and utilizes a PC-based data acquisition system for data collection and storage. A more complete description of the CTF configuration for utilizing CWFs is included in Appendix B.

This section details the results of the combustion test that was performed to generate data on the combustion and ash fouling characteristics of the Thailand CWF. The CWF was fired in the $\mathrm{CTF}$ at a rate sufficient to maintain the furnace exit gas temperature (FEGT) at $2000^{\circ} \mathrm{F}\left(1093^{\circ} \mathrm{C}\right)$, with excess air controlled to about $23 \%$. A water-cooled horizontal slag probe was inserted into the radiant zone of the furnace to evaluate slagging potential of the ash under conditions similar to the furnace walls in an utility boiler. A set of three steam-cooled Type 304 stainless steel deposition probes was inserted into the combustion chamber exit duct to collect ash fouling deposits under conditions similar to those occurring on high-temperature steam tubes located at the furnace exit in a utility boiler. The characteristics of gaseous and particulate emissions were also evaluated during the test burn as well as the relative collectibility of the fly ash from a pilot-scale electrostatic precipitator (ESP).

A video of the main components of the CTF was recorded during the test. This video was narrated to help identify combustion equipment and testing procedures. Photographs were taken during the test of the CWF flame, flue gas sampling, and various CTF components including the control panel, combustor, ductwork, ESP, and feed system. Photographs were also taken of the deposits after the test was completed. Copies of all operator's logs, run data sheets, and recorder printouts from the tests can be found in Appendix C.

\section{CWF Properties}

A sample of the as-fired Sin Pun CWF was taken from the feed hopper for analysis. This sample was submitted for proximate, ultimate, higher heating value (HHV), coal ash composition and ash fusibility. Proximate and ultimate analyses show that the fuel had a high sulfur concentration of $5.34 \mathrm{wt} \%$ at a solids loading of $56.9 \%$. Over half of the combustibles consist of volatile matter, and the fuel had an ash content of $6.47 \mathrm{wt} \%$. Table 9 shows the results of these analyses.

The results of chemical analyses, determined by $\mathrm{x}$-ray fluorescence (XRF) of the CWF ash, show that the major oxides on a wt \% basis were $\mathrm{SiO}_{2}(31 \%) ; \mathrm{Al}_{2} \mathrm{O}_{3}(10.7 \%) ; \mathrm{Fe}_{2} \mathrm{O}_{3}(14.4 \%) ; \mathrm{CaO}$ $(16.9 \%)$; and $\mathrm{SO}_{3}(23.7 \%)$. The high silica/alumina ratio $(\approx 3: 1)$ indicates that the majority of the ash-forming species are most likely present as quartz grains, with few clay mineral inclusions. While this tends to indicate a higher fouling potential, the lack of sodium and low calcium content may be expected to create weak deposits in the high-temperature regions of the convective pass.

Ash fusion temperatures were determined under oxidizing and reducing conditions. The results of these analyses indicate a relatively low fluid temperature of $2278^{\circ} \mathrm{F}\left(1248^{\circ} \mathrm{C}\right)$ under 


\section{TABLE 9}

Properties of Southern Thailand CWF

\begin{tabular}{|c|c|c|c|c|}
\hline Test Number: & AF-CTS-719 & & & \\
\hline Date: & $3 / 11 / 97$ & & & \\
\hline Fuel: & Southern Thail & & & \\
\hline Proximate Aralysis, $\%$ & As- Fired & 2 & $\mathrm{H}_{2} \mathrm{O}$ Free & Prot \\
\hline Moisture & 43.1 & & - & \\
\hline Volatile Matter & 26.19 & & 46.02 & \\
\hline Fixed Carbon & 24.24 & & 42.61 & \\
\hline Ash & 6.47 & & 11.37 & \\
\hline \multicolumn{5}{|l|}{ Ultimate Analysis, 7} \\
\hline Hydrogen & 2.43 & & 4.27 & \\
\hline Carbon & 34.91 & & 61.34 & \\
\hline Nitrogen & 0.63 & & 1.1 & \\
\hline Sulfur & 5.34 & & 9.39 & \\
\hline Oxygen & 7.13 & & 12.53 & \\
\hline Ash & 6.47 & & 11.37 & \\
\hline \multirow[t]{2}{*}{ Moisture } & 43.1 & & - & \\
\hline & $\mathrm{Btu} / \mathrm{lb}$ & $\mathrm{kJ} / \mathrm{kg}$ & $\mathrm{Btu} / \mathrm{lb}$ & $\mathrm{kJ} / \mathrm{kg}$ \\
\hline HHV & 6014 & 13988 & 10568 & 24581 \\
\hline \multirow[t]{2}{*}{ Ash Input } & $\mathrm{lb} / \mathrm{MMBu}$ & $\mathrm{kg} / \mathrm{kg}$-cảl & & \\
\hline & 10.76 & 19.37 & & \\
\hline \multirow[t]{2}{*}{ Ash Fusibility } & 30 & 18 & 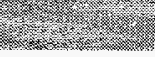 & 2.87 \\
\hline & ${ }^{\circ} \mathrm{F}$ & ${ }^{\circ} \mathrm{C}$ & ${ }^{\circ} \mathrm{F}$ & ${ }^{\circ} \mathrm{C}$ \\
\hline Initial Deformation & 2336 & 1280 & 2203 & 1206 \\
\hline Softening & 2341 & 1283 & 2237 & 1225 \\
\hline Hemisphere & 2358 & 1292 & 2240 & 1227 \\
\hline Fluid & 2476 & 1358 & 2278 & 1248 \\
\hline Oxides, wt \% & & & $\mathrm{SO}_{3}$-Free & \\
\hline $\mathrm{SiO}_{2}$ & 31.0 & & 40.7 & \\
\hline $\mathrm{Al}_{2} \mathrm{O}_{3}$ & 10.7 & & 14.0 & \\
\hline $\mathrm{Fe}_{2} \mathrm{O}_{3}$ & 14.4 & & 18.9 & \\
\hline $\mathrm{TiO}_{2}$ & 0.5 & & 0.6 & \\
\hline $\mathrm{P}_{2} \mathrm{O}_{5}$ & 0.2 & & 0.3 & \\
\hline $\mathrm{CaO}$ & 16.9 & & 22.1 & \\
\hline MgO & 2.2 & & 2.9 & \\
\hline $\mathrm{Na}_{2} \mathrm{O}$ & 0.0 & & 0.0 & \\
\hline $\mathrm{K}_{2} \mathrm{O}$ & 0.3 & & 0.4 & \\
\hline $\mathrm{SO}_{3}$ & 23.7 & & - & \\
\hline Total & 99.9 & & 99.9 & \\
\hline
\end{tabular}


reducing conditions. This indicates that excess air levels should be maintained above some minimum level, perhaps $20 \%\left(3.5 \% \mathrm{O}_{2}\right)$, dry basis.

Calculations to estimate solid and liquid mineral phases and ash viscosity of the CWF as a function of temperature were performed by using PHOEBE, an equilibrium thermodynamic model developed at the EERC based on the minimization of Gibbs' free energy. The results of the PHOEBE calculations of ash viscosity and percentage of liquid mineral phases versus temperature are shown in Figures 6 and 7, respectively. Note that viscosity is calculated only for the liquidphase material present. Ash will flow readily at 250 poise. The temperature at which the ash attains a viscosity of 250 poise is called $\mathrm{T}_{250}$ and is used by cyclone and wet-bottom boiler operators to assess the potential for maintaining a consistent slag flow from a given fuel. Operators of pulverized coal-fired units would be inclined to either fire a fuel with a $T_{250}$ greater than the operating FEGT or control the FEGT well below this value. The relatively narrow temperature range over which these phenomena can occur can be observed in some pulverized coal units, particularly those with an upper furnace suspended surface preceding secondary superheat surfaces, where tacky or liquid ash may occur at the bottom of the secondary superheat surface while dry powder exists at the top. The liquid mineral phase, which is less than $20 \%$ of the ash, consists almost entirely of $\mathrm{CaMgSi}_{2} \mathrm{O}_{6}$ and is the line shown on Figure 7. This phase does not become liquid until $2050^{\circ} \mathrm{F}\left(1121^{\circ} \mathrm{C}\right)$, indicating that minimal fouling would take place at temperatures near $2000^{\circ} \mathrm{F}\left(1093^{\circ} \mathrm{C}\right)$. Although the model predicts low viscosity for this liquid phase, there is very little available liquid material to sinter ash deposits at the temperatures discussed here. The model predicts that some increased fouling will occur at a FEGT above $2100^{\circ} \mathrm{F}\left(1150^{\circ} \mathrm{C}\right)$.

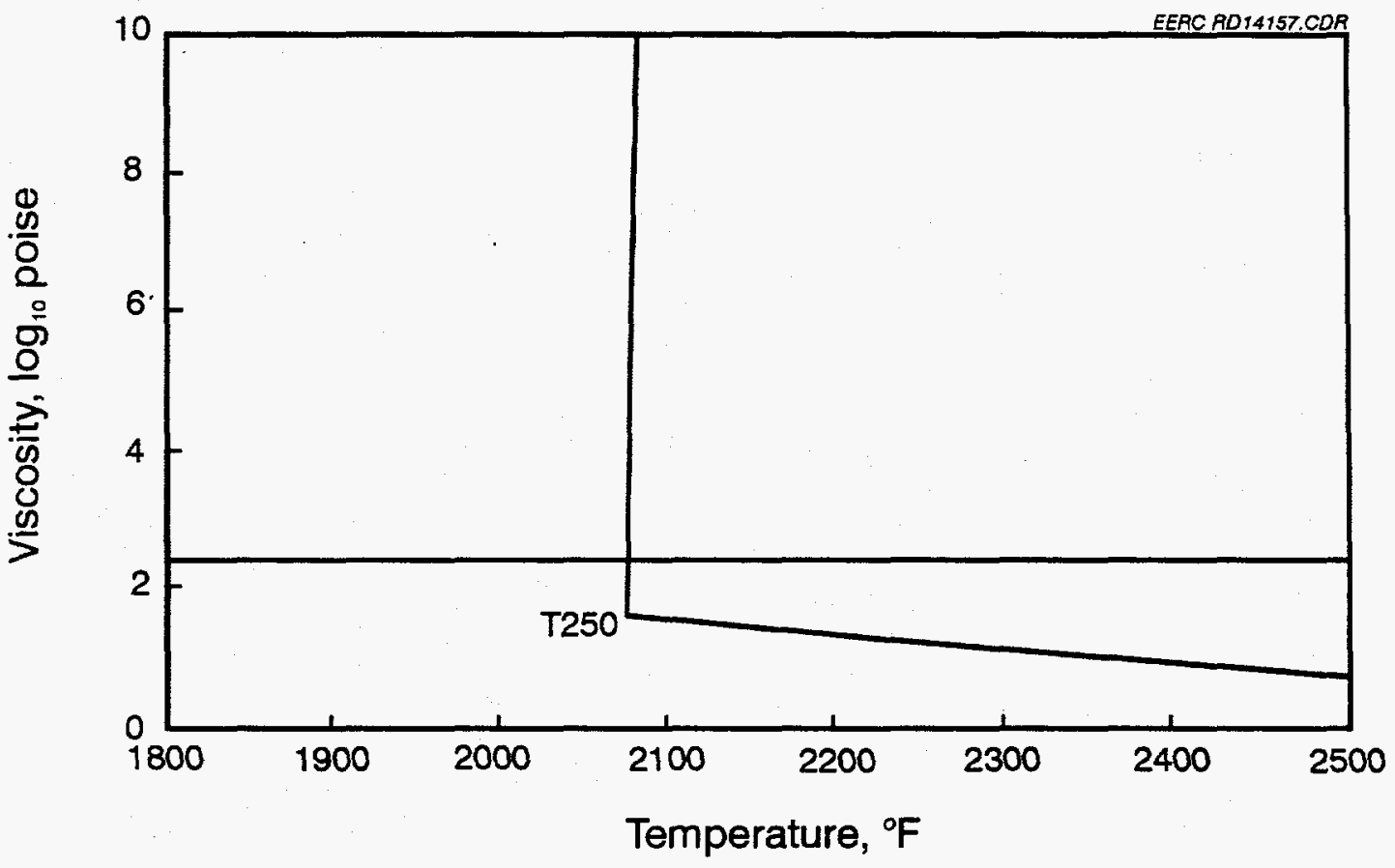

Figure 6. Coal analysis - viscosity PHOEBE results. 


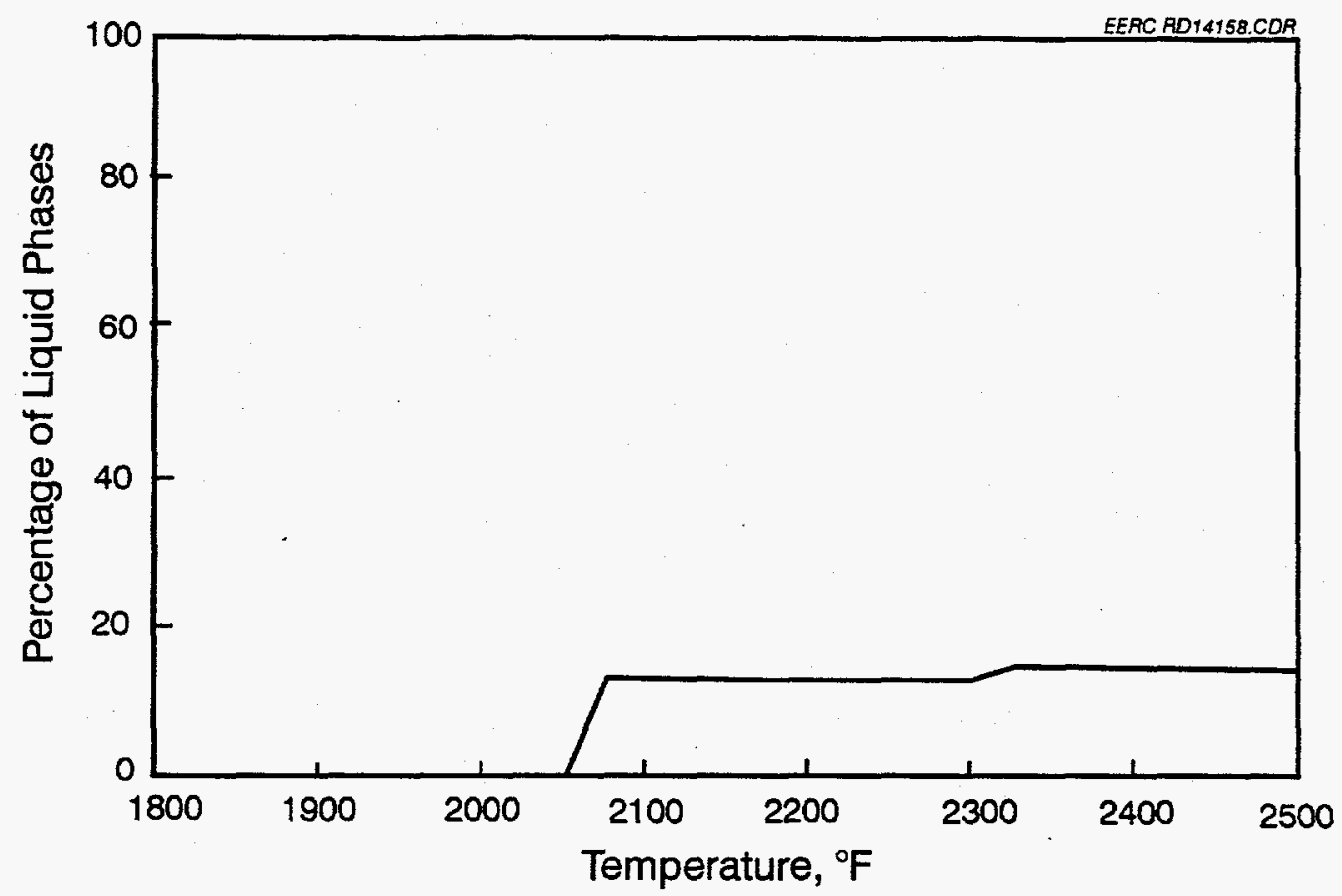

Figure 7. Coal analysis - liquid-phase PHOEBE results.

\section{Combustor Operating Parameters}

A standard 5.25-hr CWF combustion test, AF-CTS-719, was performed on March 11, 1997, to generate data on the combustion and ash fouling characteristics of the Thailand CWF. The CWF was fired in the CTF at an average rate of $123 \mathrm{lb} / \mathrm{hr}(55.8 \mathrm{~kg})$, with an average FEGT of $2005^{\circ} \mathrm{F}$ $\left(1096^{\circ} \mathrm{C}\right)$.

Feed rates were measured with a mass flowmeter and displayed on a digital readout. A calibration of the flowmeter was performed at the end of the run because of a $36 \%$ discrepancy between the amount of fuel fed indicated by the totalizer compared to the fuel fed based on a weighback method. The final totalizer reading indicated that $473 \mathrm{lb}(214.6 \mathrm{~kg})$ had been fired, while weighbacks indicated that $649 \mathrm{lb}(294.4 \mathrm{~kg})$ had been fed. This calibration verified that the totalizer was indicating a $36 \%$ lower flow rate than actual. Using this difference, the totalizer and weighback methods of determining feed rates correlate very closely $(645.5 \mathrm{lb}$ or $292.8 \mathrm{~kg}$ for the totalizer and $649 \mathrm{lb}$ or $294.4 \mathrm{~kg}$ for weighback). The corrected totalizer feed rates are probably more accurate than those from the weighback, as the weighback does not account for the fuel that was not recovered at the beginning of the test, when pluggage occurred because of foreign material that was found in the slurry or possibly slight evaporation in the feed tank.

Combustion air settings were adjusted to achieve an average excess air level of $23 \%$. The atomizing air flow (9\% of total combustion air) was set to obtain good atomization of the CWF. Unheated primary air averaged $6 \%$ of the total flow, and $85 \%$ of the total flow was introduced as secondary air preheated to $500^{\circ} \mathrm{F}\left(260^{\circ} \mathrm{C}\right)$. The secondary air register was set to achieve a swirl number of 0.9 . No tertiary air was used for this run. These settings provided for a stable flame and 
instantaneous ignition of the fuel, which was verified by low carbon values in the ash. Figure 8 is a photograph of the CWF flame.

The horizontal slag probe inserted in the furnace was cooled to an average skin temperature of $739^{\circ} \mathrm{F}\left(393^{\circ} \mathrm{C}\right)$. Three steam-cooled deposition probes inserted in the duct at the furnace exit were used to determine convective pass fouling tendencies. These probes collected deposits over a 5.25 -hr test period, with the surface metal temperature maintained at $1000^{\circ} \mathrm{F}\left(538^{\circ} \mathrm{C}\right)$.

The concentrations of $\mathrm{O}_{2}, \mathrm{CO}_{2}, \mathrm{SO}_{2}$, and $\mathrm{NO}_{x}$ were continuously monitored at a port located just after the probe bank. Excess air was controlled to approximately $23 \%\left(3.83 \% \mathrm{O}_{2}\right)$ during the combustion test. The ESP used to collect the ash in the flue gas had an average inlet temperature of $331^{\circ} \mathrm{F}\left(166^{\circ} \mathrm{C}\right)$ and outlet temperature of $286^{\circ} \mathrm{F}\left(141^{\circ} \mathrm{C}\right)$. A summary of the main combustor operating parameters is provided in Table 10.

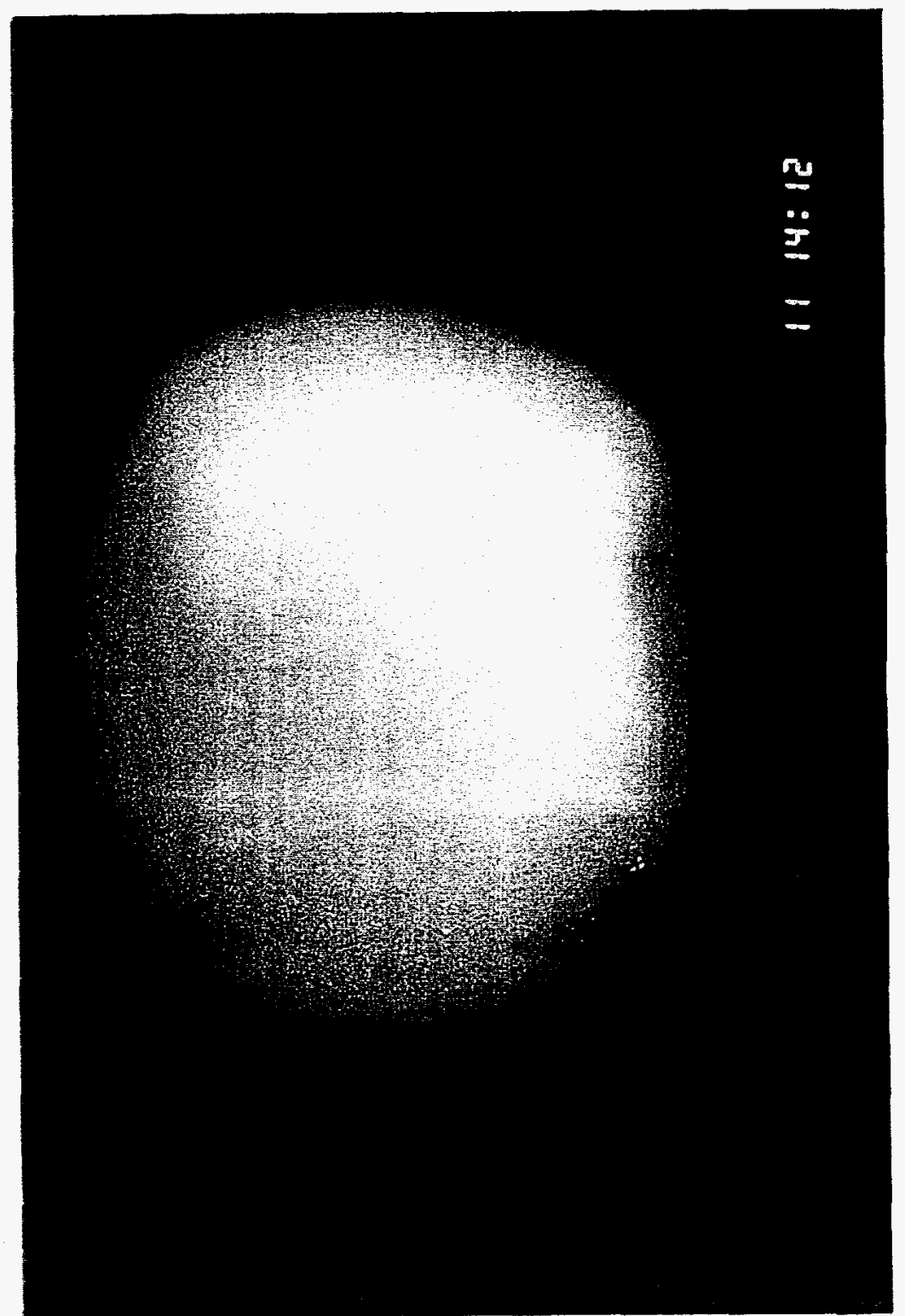

Figure 8. Southern Thailand CWF flame. 
TABLE 10

Summary of Combustor Operating Parameters - Test Averages

Test Number: AF-CTS-719

Date of Test: $3 / 11 / 97$

Fuel: $\quad$ Southern Thailand CWF

Total CWF Burned, lb

Burn Time on Fuel, hr

645.5

5.25

CWF Feed Rate, $\mathrm{lb} / \mathrm{hr}$

Heat Input, Btu/hr

Furnace Exit Gas Temperature, ${ }^{\circ} \mathrm{F}$

Ash Fouling Probe Metal

Temperature, ${ }^{\circ} \mathrm{F}$

Horizontal Slag Probe Metal

Temperature, ${ }^{\circ} \mathrm{F}$

Flue Gas Analysis, dry, v/v

$\mathrm{O}_{2}, \%$

$\mathrm{CO}_{2}, \%$

$\mathrm{CO}, \%$

$\mathrm{SO}_{2}, \mathrm{ppm}$

$\mathrm{NO}_{\mathrm{x}}, \mathrm{ppm}$

Flue Gas Moisture, \% v/v

Excess Air, \%

Combustion Air, scfh

Atomizing Air

Primary Air

Secondary Air

Swirl Number

ESP Specific Collection Area

System Temperatures, ${ }^{\circ} \mathrm{F}$

Coal-Water Fuel

Atomizing Air

Primary Air

Secondary Air

Probe Bank Exit

ESP Inlet

ESP Outlet

Induced-Draft Fan Inlet

Stack

System Pressures

Forced-Draft Fan Exit Static, in. $\mathrm{H}_{2} \mathrm{O}$

CWF Feed Pressure, psig

Atomizing Air, psig

Combustor Static, in. $\mathrm{H}_{2} \mathrm{O}$

ESP Inlet Static, in. $\mathrm{H}_{2} \mathrm{O}$

ESP Outlet Static, in. $\mathrm{H}_{2} \mathrm{O}$

Induced-Draft Fan Inlet Static, in. $\mathrm{H}_{2} \mathrm{O}$
123

739421

2005

1008

739

3.83

15.05

na

6252

679

17.4

22.75

742

582

7368

0.9

75.18

72

72

93

500

1651

331

286

227

179

65.7

100.0

36.4

$-0.3$

$-8.5$

$-11.0$

$-19.2$
SI Units

$292.8 \mathrm{~kg}$

$55.8 \mathrm{~kg} / \mathrm{hr}$

$780530 \mathrm{~kJ} / \mathrm{hr}$

$1096^{\circ} \mathrm{C}$

$542^{\circ} \mathrm{C}$

$393^{\circ} \mathrm{C}$
$21.01 \mathrm{~m}^{3} / \mathrm{hr}$

$16.48 \mathrm{~m}^{3} / \mathrm{hr}$

$208.66 \mathrm{~m}^{3} / \mathrm{hr}$

$22^{\circ} \mathrm{C}$

$22^{\circ} \mathrm{C}$

$34^{\circ} \mathrm{C}$

$260^{\circ} \mathrm{C}$

$899^{\circ} \mathrm{C}$

$166^{\circ} \mathrm{C}$

$141^{\circ} \mathrm{C}$

$108^{\circ} \mathrm{C}$

$82^{\circ} \mathrm{C}$

$1.63 \mathrm{kPa}$

$7.03 \mathrm{~kg} / \mathrm{cm}^{2}$

$2.56 \mathrm{~kg} / \mathrm{cm}^{2}$

$-0.01 \mathrm{kPa}$

$-0.21 \mathrm{kPa}$

$-0.27 \mathrm{kPa}$

$-0.48 \mathrm{kPa}$ 


\section{Summary of Ash Results}

\section{Ash Probe Deposit Characterization}

Photographs of the deposits formed on the steam-cooled convective pass probes were taken at the completion of the test burn. The ash was then collected and analyzed.

The sintered ash deposits that formed on the north and middle steam-cooled probes in the probe duct arose from deposit growth initiated on the refractory wall in the duct. The ash was reddish brown in color and medium in hardness. Figures 9 and 10 are photographs of the ash formed in the probe bank area. Figure 9 shows the probe bank removed from the duct and the ash remaining in the duct. As seen in the photograph, most of the sintered ash deposit that had initiated from the refractory walls of the duct and probe bank remained in the duct when the probes were removed. The photos also show a portion of this sintered ash that remained on the probe bank. $\mathrm{X}$-ray fluorescence analyses (XRFA) and scanning electron microscope point count (SEMPC) results of this ash (Table 11) indicate high amounts of quartz-and silicon-rich particles. X-ray diffraction (XRD) results for this ash (Table 12) also shows the major mineral component of the probe bank duct ash is quartz. The major/minor components of quartz, hematite, calcium silicates, and calcium sulfate are typical of fuel having high Si/Al ratios with moderate alkali and alkalineearth elements and lower FEGT temperatures.

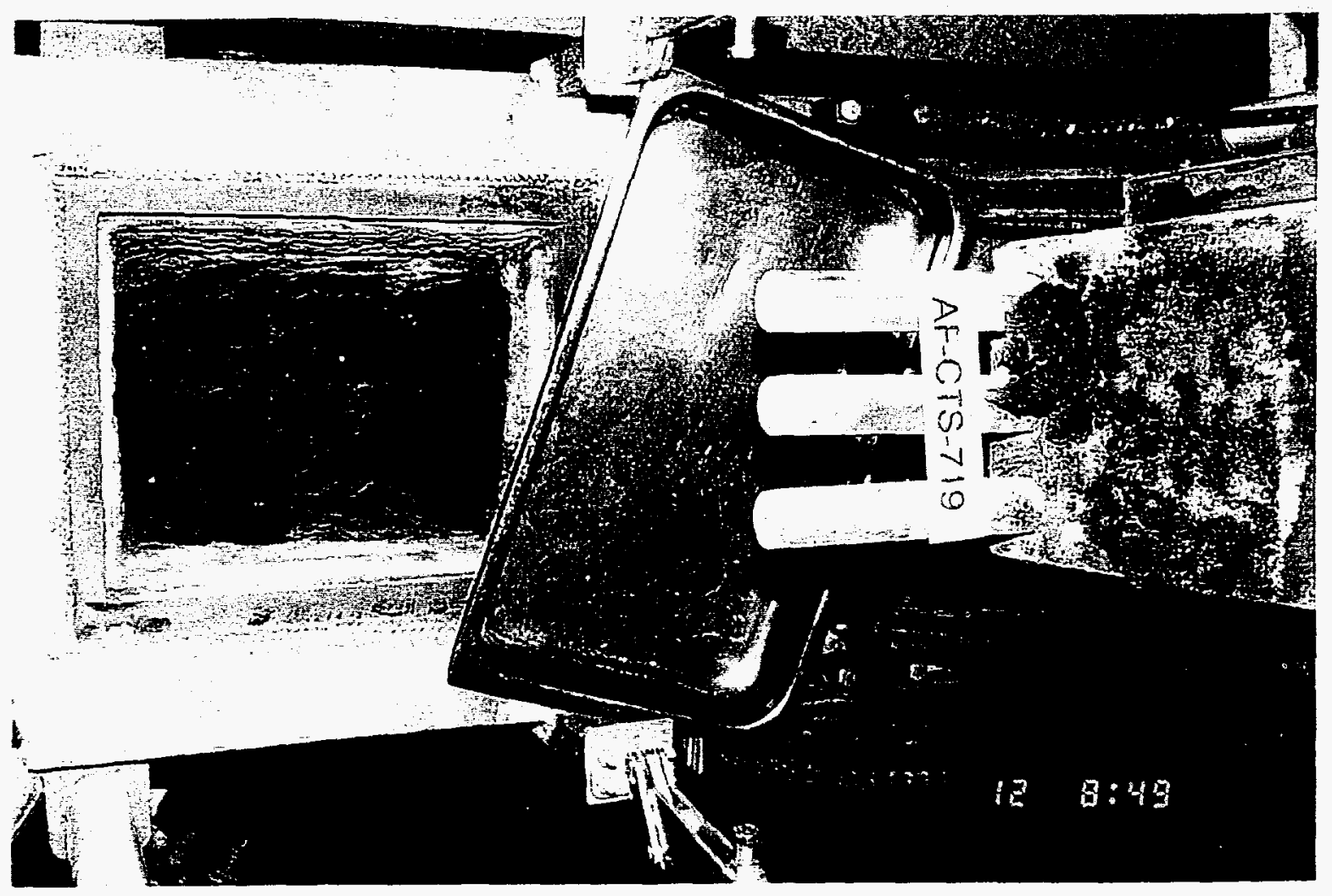

Figure 9. Probe bank duct ash deposits. 


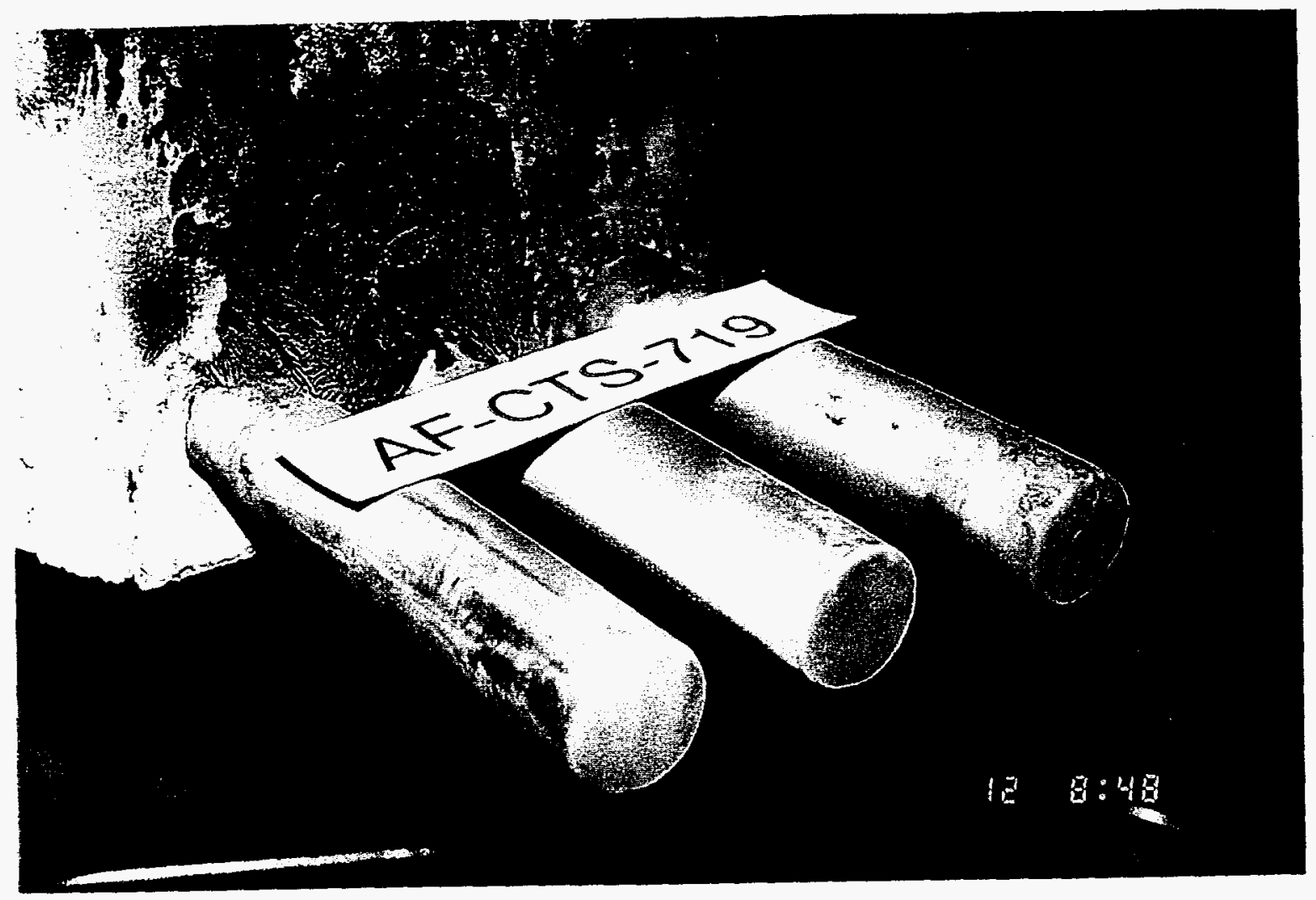

Figure 10. Probe bank deposits.

\section{TABLE 11}

SEMPC and XRF Analyses of Probe Bank Duct Deposits

\begin{tabular}{ll}
\hline Test Number: & $\begin{array}{l}\text { AF-CTS-719 } \\
\text { Date: }\end{array}$ \\
Fuel: & Southern Thailand CWF \\
\hline Particle Types, \% of & \\
Total Count & 3.2 \\
Pyrite & 1.6 \\
Calcium Sulfate & 4.0 \\
Mixed Sulfur-Rich & 1.2 \\
Mixed Carbon-Rich & 30.4 \\
Quartz & 3.2 \\
Anorthite & 3.2 \\
Montmorillonite & 0.4 \\
Pyroxene & 5.2 \\
Wollastonite & 43.2 \\
Mixed Silicon-Rich & 4.4 \\
Other & 100 \\
\hline
\end{tabular}


Table 11 (continued)

\begin{tabular}{lccc}
\hline Average Composition, wt & SEMPC & SEMPC & XRF \\
\hline & Bulk & Si-Rich & Results \\
\hline $\mathrm{SiO}_{2}$ & 49.3 & 31.8 & 49.9 \\
$\mathrm{Al}_{2} \mathrm{O}_{3}$ & 9.9 & 14.5 & 7.7 \\
$\mathrm{Fe}_{2} \mathrm{O}_{3}$ & 15.0 & 22.9 & 18.5 \\
$\mathrm{TiO}_{2}$ & 0.3 & 0.4 & 0.5 \\
$\mathrm{P}_{2} \mathrm{O}_{5}$ & 0.1 & 0.2 & 0.0 \\
$\mathrm{CaO}$ & 19.2 & 25.8 & 16.8 \\
$\mathrm{MgO}$ & 1.2 & 1.7 & 0.8 \\
$\mathrm{Na} \mathrm{O}_{2} \mathrm{O}$ & 0.2 & 0.2 & 0.1 \\
$\mathrm{~K}_{2} \mathrm{O}$ & 0.2 & 0.2 & 0.3 \\
$\mathrm{SO}_{3}$ & 4.5 & 2.3 & 5.4 \\
Total & 100 & 100 & 100 \\
Total Count, Points & 250 & 108 & \\
\hline
\end{tabular}

TABLE 12

Results of XRD Analysis -

Probe Bank Duct Sintered, Probe Bank, Horizontal Slag Probe, and ESP No. 1 Ash

\begin{tabular}{lcccc}
\hline Mineral Component & Probe Bank & Probe & Horizontal & ESP No. 1 \\
\hline Quartz $\left(\mathrm{SiO}_{2}\right)$ & Major & Minor & Major & Major \\
Anhydrite $\left(\mathrm{CaSO}_{4}\right)$ & Minor & Minor & Minor & Minor \\
Hematite $\left(\mathrm{Fe}_{2} \mathrm{O}_{8}\right)$ & Minor & Minor & Minor & Minor \\
Clinopyrozene $\left(\mathrm{Ca}(\mathrm{Fe}, \mathrm{Mg}, \mathrm{Al}) \mathrm{Si}_{2} \mathrm{O}_{6}\right)$ & Minor & Minor & - & - \\
Augite $\left(\mathrm{Ca}(\mathrm{Mg}, \mathrm{Fe}) \mathrm{Si}_{2} \mathrm{O}_{6}\right)$ & Minor & - & Minor & Minor \\
Cristobalite $\left(\mathrm{SiO}_{2}\right)$ & Minor & - & - & - \\
Ferrite Spinel $\left(\left(\mathrm{Mg}, \mathrm{Fe}, \mathrm{Fe}, \mathrm{Al}_{2} \mathrm{O}_{8}\right)\right.$ & - & Minor & - & - \\
\hline
\end{tabular}

The computer program VISCALC developed at the EERC calculates viscosities for silicate phases from the point-by-point SEMPC analysis using a modified form of the Urbain equation. Viscosities were calculated by VISCALC for the probe bank duct ash, with the percentage of the deposit with viscosities less than 250 poise $\left(\mathrm{T}_{250}\right)$ plotted as a function of temperature. The median viscosity of the duct ash crosses $\mathrm{T}_{250}$ at ${ }^{-} 2425^{\circ} \mathrm{F}\left(1329^{\circ} \mathrm{C}\right)$. Figure 11 plots the cumulative percent versus viscosities $\left(\log _{10}\right.$ poise) for three temperatures. At $1832^{\circ} \mathrm{F}\left(1000^{\circ} \mathrm{C}\right)$, less than $1 \%$ of the ash is lower than $\mathrm{T}_{250}$. At $2012^{\circ} \mathrm{F}\left(1100^{\circ} \mathrm{C}\right), 5 \%$ is less than $\mathrm{T}_{250}$, and at $2192^{\circ} \mathrm{F}\left(1200^{\circ} \mathrm{C}\right), 29 \%$ of the ash is less than $T_{250}$. This indicates that at low temperatures, the ash has low fouling potential and should be easily sootblown from convective pass boiler tubes. This supports the results of the CTF combustion test, which showed very little or no fouling deposit formation at $2000^{\circ} \mathrm{F}$. Firing of the Sin Pun CWF at an FEGT above $2000^{\circ} \mathrm{F}$ should be approached with caution. Modeling and analytical results indicate a significant change in deposit character may occur at temperatures above $2050^{\circ} \mathrm{F}$. No deposits were formed at higher temperatures to establish deposit properties. Careful 


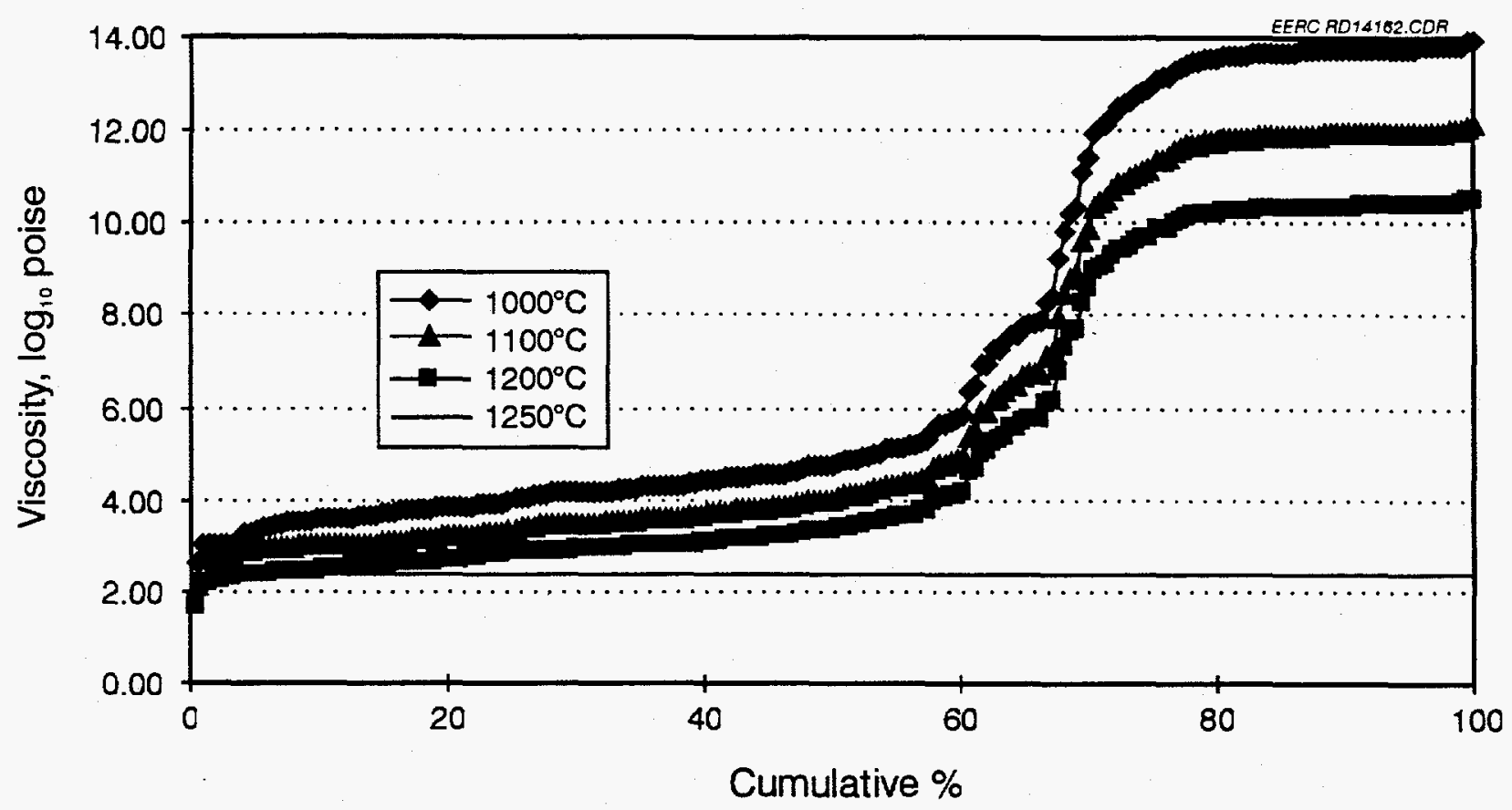

Figure 11. Probe bank duct ash viscosity results.

examination of boiler tube fouling as a function of temperature above this threshold should be performed at full-scale or pilot-scale prior to establishing a higher FEGT as a normal boiler operating parameter.

The soft ash that was next to the probes was reddish brown in color. This ash (identified as probe bank) was brushed off and submitted for XRFA, XRD, and carbon-hydrogen-nitrogen (CHN) analyses. There was a rough enamel layer of ash that had formed on the probe surface that did not brush off, but was removed with sanding. XRFA results are reported as oxides on a weight percent basis and on a $\mathrm{SO}_{3}$-free basis in Table 13 . These results indicate that a majority of the ash consists of quartz, iron, and calcium. There is also $13.7 \% \mathrm{SO}_{3}$, which could be combined with the iron or calcium as sulfated mineral components. This could be attributed to the cooler probe surfaces, which favor sulfate deposits to form. The adhesion of these sulfated deposits to the probes was strong enough to prevent the erosion from impacting ash particles. XRD results (Table 12) do not list any major phases for the probe bank ash. CHN analysis of the ash showed there was good burnout of the fuel at this point, with only $0.16 \mathrm{wt} \%$ carbon in the ash.

\section{Slag Probe Deposit Characterization}

The ash that was deposited on the horizontal slag probe was a dark, reddish brown color. Figure 12 is a photograph of those deposits. It was deposited to a thickness of about $1 / 8$ in. ( $3 \mathrm{~mm}$ ) thick on the top surface. The ash was soft and easily brushed off. XRD results show quartz $\left(\mathrm{SiO}_{2}\right)$ to be the major crystalline phase. XRFA results (Table 13) also agree, with over $50 \%$ of the ash consisting of $\mathrm{SiO}_{2}$. There was less than $1 \%$ carbon in the ash collected from this probe. High quartz or silica content with minor oxides and silicate minerals are often associated with high- viscosity, nonsticky or more dry types of deposits and not usually prone to troublesome slag formation. 


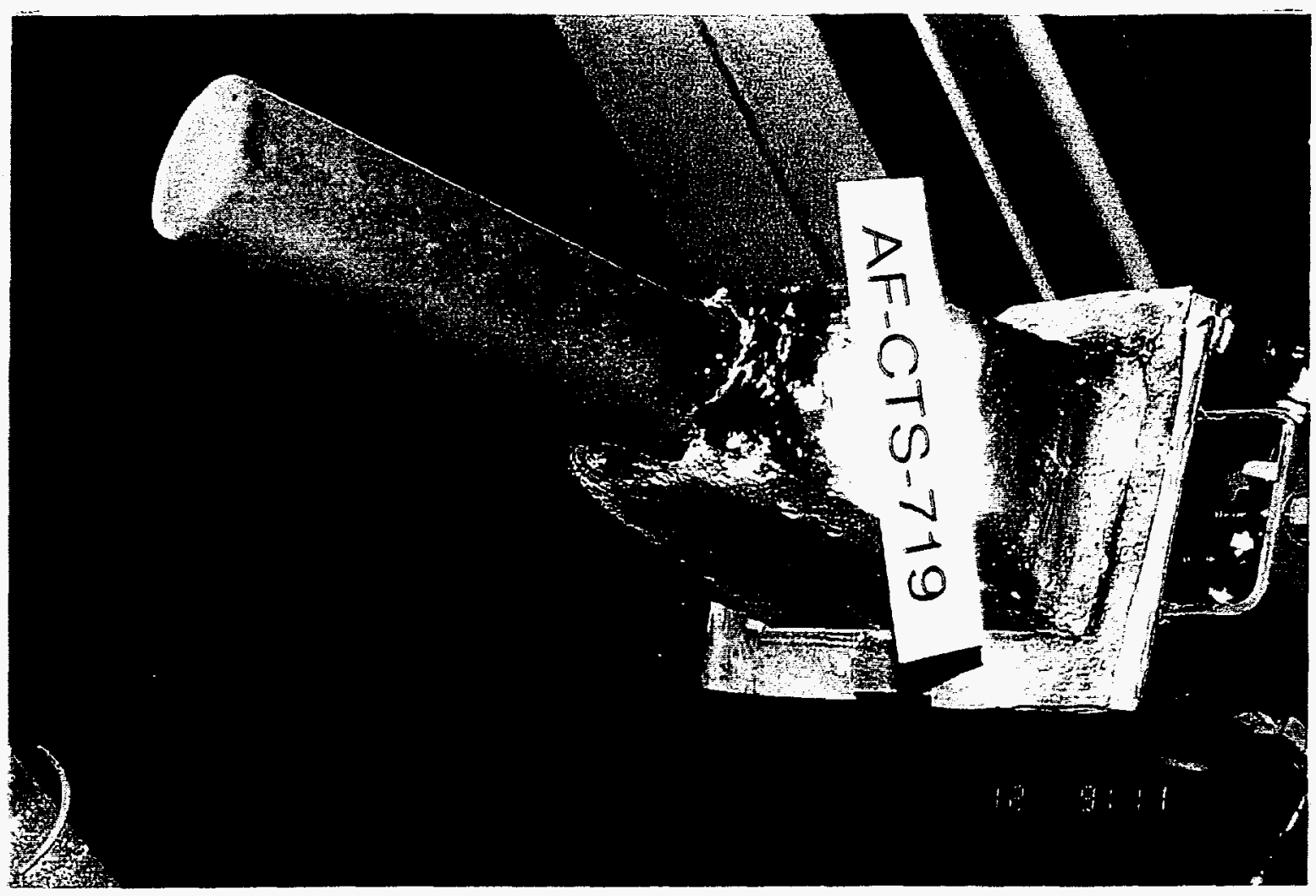

Figure 12. Horizontal slag probe ash deposits.

\section{System Ash Characterization}

The results of a mass balance performed after the completion the test burn are presented in Table 14. These samples accounted for only $43 \%$ of the total ash input from the fuel. A significant portion of the unaccounted for ash was likely emitted from the stack, either as a fine gas or solid particulate. Collection efficiency of the ESP was less than $90 \%$ for this run. (ESP performance is discussed below.) Figure 13 shows the combustor bottom and ash deposits that were formed. This sintered ash was easily removed, with no evidence of any heavy slagging deposition. Selected ash samples were collected and submitted for analyses (Table 13). All of the samples submitted for carbon determination indicate that the CWF burned well in the CTF. XRFA results show that $\mathrm{SiO}_{2}$ is the dominant component of the ash samples taken.

\section{Stack Emissions and ESP Performance}

Particulate concentrations at the inlet and exit of the ESP were determined using the U.S. Environmental Protection Agency (EPA) Method 5 protocol. Two sets of isokinetic sampling were performed to provide data on the collection efficiency of the ESP and the particle-size distribution of the ash entering the ESP. The first set consisted of an inlet and outlet dustloading, which were performed simultaneously. The ash for these dustloadings was collected on bulk filters. This set indicated a collection efficiency of $89 \%$. For the second set of sampling, a five-stage multicyclone with a backup filter was used to get an aerodynamic size distribution of the ash entering the ESP while the outlet dust loading was collected with a bulk filter. These dust loadings were also performed simultaneously. The ESP had a collection efficiency of $87 \%$ during this sampling period. The results of these dust loadings are presented in Table 15 . The multicyclone data are 
TABLE 13

Analyses of Selected Ash Deposits

\begin{tabular}{|c|c|c|c|c|c|c|c|c|c|c|}
\hline $\begin{array}{l}\text { Test Number: } \\
\text { Date: } \\
\text { Fuel: }\end{array}$ & $\begin{array}{l}\text { AF-CTS-719 } \\
3 / 11 / 97 \\
\text { Southern Tha }\end{array}$ & and CWF & & & & & & & & \\
\hline Fuel: & $\begin{array}{c}\text { Horizontal } \\
\text { Probe }\end{array}$ & $\begin{array}{c}\text { Horizontal } \\
\text { Probe }\end{array}$ & $\begin{array}{l}\text { Probe } \\
\text { Bank }\end{array}$ & $\begin{array}{l}\text { Probe } \\
\text { Bank } \\
\end{array}$ & $\begin{array}{c}\text { Probe Bank } \\
\text { Duct }\end{array}$ & $\begin{array}{c}\text { Probe Bank } \\
\text { Duct }\end{array}$ & $\begin{array}{c}\text { ESP } \\
\text { No. } 1 \\
\end{array}$ & $\begin{array}{c}\text { ESP } \\
\text { No. } 1 \\
\end{array}$ & $\begin{array}{l}\text { ESP } \\
\text { Final } \\
\end{array}$ & $\begin{array}{l}\text { Sampling } \\
\text { Cyclone }\end{array}$ \\
\hline Carbon, wt\% & 0.93 & - & 0.16 & - & - & - & 0.66 & - & 0.84 & 0.5 \\
\hline Oxides, wt \% & $\mathbf{N}$ & $\mathbf{R}$ & $\mathbf{N}$ & $\mathrm{R}$ & $\mathbf{N}$ & $\mathbf{R}$ & $\mathbf{N}$ & $\mathbf{R}$ & & \\
\hline $\mathrm{SiO}_{2}$ & 51.0 & 56.8 & 28.9 & 33.5 & 49.9 & 52.7 & 46.1 & 49.8 & - & - \\
\hline $\mathrm{Al}_{2} \mathrm{O}_{3}$ & 7.2 & 8.0 & 10.6 & 12.3 & 7.7 & 8.1 & 8.2 & 8.9 & - & - \\
\hline $\mathrm{Fe}_{2} \mathrm{O}_{3}$ & 16.0 & 17.9 & 23.4 & 27.1 & 18.5 & 19.5 & 19.0 & 20.5 & - & - \\
\hline $\mathrm{TiO}_{2}$ & 0.4 & 0.5 & 0.2 & 0.3 & 0.5 & 0.5 & 0.5 & 0.6 & - & - \\
\hline $\mathrm{P}_{2} \mathrm{O}_{5}$ & 0.0 & 0.0 & 0.1 & 0.1 & 0.0 & 0.0 & 0.0 & 0.0 & - & - \\
\hline $\mathrm{CaO}$ & 13.5 & 15.0 & 19.9 & 23.0 & 16.8 & 17.8 & 17.1 & 18.5 & - & - \\
\hline $\mathrm{MgO}$ & 1.0 & 1.1 & 2.1 & 2.4 & 0.8 & 0.9 & 1.0 & 1.1 & - & - \\
\hline $\mathrm{Na}_{2} \mathrm{O}$ & 0.2 & 0.2 & 0.3 & 0.4 & 0.1 & 0.1 & 0.1 & 0.1 & - & - \\
\hline $\mathrm{K}_{2} \mathrm{O}$ & 0.4 & 0.5 & 0.9 & 1.1 & 0.3 & 0.4 & 0.4 & 0.5 & - & - \\
\hline $\mathrm{SO}_{3}$ & 10.3 & - & 13.7 & - & 5.4 & - & 7.5 & - & - & - \\
\hline
\end{tabular}

$\mathrm{N}=$ normalized to $100 \%$ closure.

$\mathrm{R}=$ renormalized to $\mathrm{SO}_{3}$-free basis . 
TABLE 14

System Ash Mass Balances

Test Number: AF-CTS-719

Date: $\quad 3 / 11 / 97$

Fuel: $\quad$ Southern Thailand CWF

Test Duration, hr

Total Fuel Burned, lb

646

Total Fuel Burned, kg

292.80

Ash Input Rate, lb/MMBtu

10.76

Ash Input Rate, $\mathrm{kg} / \mathrm{kg}$-cal

19.37

Total Ash Input, lb

41.76

Total Ash Input, $g$

18942

Ash Balance

Furnace, 8

1828.2

Horizontal Slag Probe

77.0

Total

1905.2

$\%$ of Input

10.06

Probe Area, $g$

Probe Bank

28.0

Probe Bank Duct

2503.6

Total

2531.6

$\%$ of Input

13.36

Heat

Exchangers,

Horizontal

81.8

Air-Cooled

80.3

Total

162.1

$\%$ of Input

0.86

Electrostatic Precipitator

Hopper Catch

3114.2

Sampling Cyclone

59.6

Flue Gas Piping

160.0

Bypass Cyclone

279.1

Total

3612.9

$\%$ of Input

19.07

Unaccounted for, $g$

$\%$ of Input

10730.5

56.65 


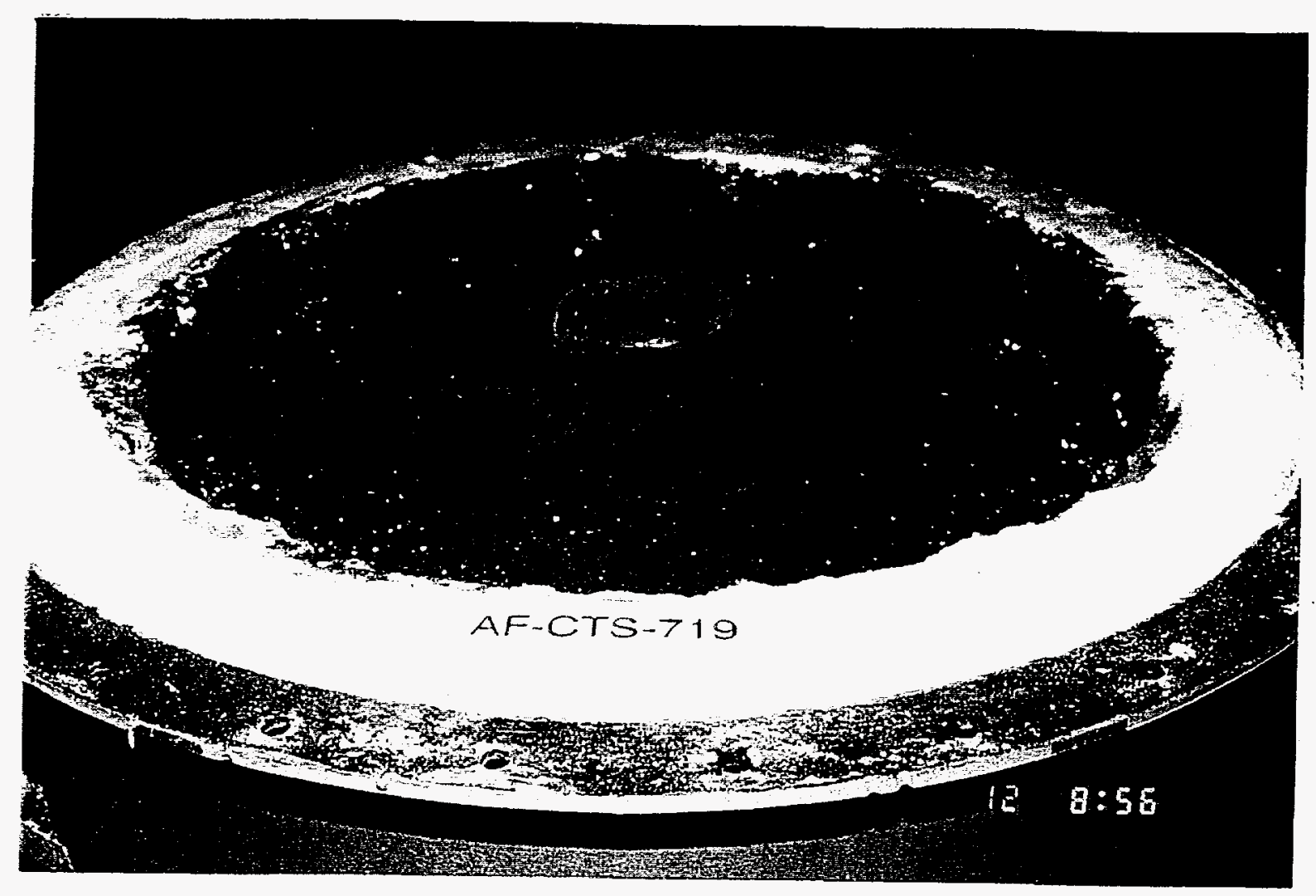

Figure 13. Combustor bottom ash deposits.

presented in Table 16 . The $D_{50}$ particle size is reported for each cyclone in $\mu \mathrm{m}$. Figure 14 plots the cumulative mass percent of these particles on a log scale.

The ESP collection hopper was emptied during the run to get a sample. This sample is referred to ESP No. 1. This ash was submitted for XRD (Table 12), XRFA and carbon determination (Table 13), and for particle-size determination (Figure 15). The ESP collection hopper was emptied again at the end of the run and submitted for carbon determination. This sample is identified as ESP Final.

The ESP obtained a collection efficiency of less than $90 \%$ for this run. This may not be entirely due to the ash characteristics, but rather to a low specific collection area (SCA). The SCA is defined as the effective collecting-electrode surface area per thousand acfm of gas treated. Depending upon the physical, chemical, and electrical characteristics of the coal ash, precipitator SCAs range from 300 to 1000 for collection efficiencies above $99.5 \%$.(4) Higher flow rates through the ESP for the test burn of the CWF resulted in a SCA of $75.18 \mathrm{ft}^{2} / 1000 \mathrm{scfm}$.

Figure 16 is a graph of the calculated resistivity (R) of the CWF ash in ohm-cm, predicted by the Bickelhaupt Model (5). The CWF resistivity of $1 \times 10^{14}$ at $300^{\circ} \mathrm{F}\left(150^{\circ} \mathrm{C}\right)$ is high. Resistivities between $1 \times 10^{8}$ and $2 \times 10^{10} \mathrm{ohm}$-cm usually are normal for satisfactory and predictable precipitator design. Ashes with resistivities greater than $5 \times 10^{10} \mathrm{ohm}$-cm generally are difficult to collect. The high resistivity calculated from the Bickelhaupt Model is caused in part by the high concentrations of silica, alumina, and calcium. Combustion Engineering, Inc. (4) states that ash resistivity is inversely proportional to the concentration of sulfur trioxide and moisture in the flue gas and is directly proportional to the ash constituents of calcium, magnesium, alumina, and silica. 
TABLE 15

ESP Dust-Loading Results

\begin{tabular}{|c|c|c|c|c|}
\hline Test Number: & AF-CTS-719 & & & \\
\hline Date: & $3 / 11 / 97$ & & & \\
\hline \multirow[t]{3}{*}{ Fuel: } & \multicolumn{4}{|c|}{ Southern Thailand CWF } \\
\hline & $\begin{array}{l}\text { ESP Inlet } \\
\text { No. } 1\end{array}$ & $\begin{array}{l}\text { ESP Outlet } \\
\text { No. } 1\end{array}$ & $\begin{array}{l}\text { ESP Inlet } \\
\text { No. } 2\end{array}$ & $\begin{array}{l}\text { ESP Outlet } \\
\text { No. } 2\end{array}$ \\
\hline & Dust Loading & Dust Loading & Dust Loading & Dust Loading \\
\hline Time & $13: 54: 00$ & $13: 54: 00$ & $15: 23: 00$ & $15: 23: 00$ \\
\hline Duration, min & 60 & 60 & 60 & 62 \\
\hline Dust Collected, $\mathrm{g}$ & 6.34449 & 0.51408 & 5.9906 & 0.77178 \\
\hline Grains/scf & 2.6479 & 0.2923 & 2.7011 & 0.3561 \\
\hline \% Efficiency & - & 88.962 & - & 86.818 \\
\hline \% Isokinetic & 101.5 & 104.1 & 100.3 & 103.2 \\
\hline
\end{tabular}

TABLE 16

Inlet ESP Multicyclone Results

Test

Number: AF-CTS-719

Date: $\quad 3 / 11 / 97$

Fuel: $\quad$ Southern Thailand CWF

\begin{tabular}{|c|c|c|c|c|}
\hline & Mass, $\mathrm{g}$ & $\begin{array}{c}\text { Percent } \\
\text { Total } \\
\end{array}$ & $\begin{array}{l}\mathrm{D}_{50} \\
\mu \mathrm{m} \\
\end{array}$ & Cumulative Percent \\
\hline Stage 1 & 5.4292 & 90.63 & 7.66 & 9.37 \\
\hline Stage 2 & 0.3548 & 5.92 & 4.45 & 3.45 \\
\hline Stage 3 & 0.1373 & 2.29 & 2.34 & 1.16 \\
\hline Stage 4 & 0.0333 & 0.56 & 1.64 & 0.60 \\
\hline Stage 5 & 0.0210 & 0.35 & 0.69 & 0.25 \\
\hline Filter & 0.0150 & 0.25 & & \\
\hline
\end{tabular}




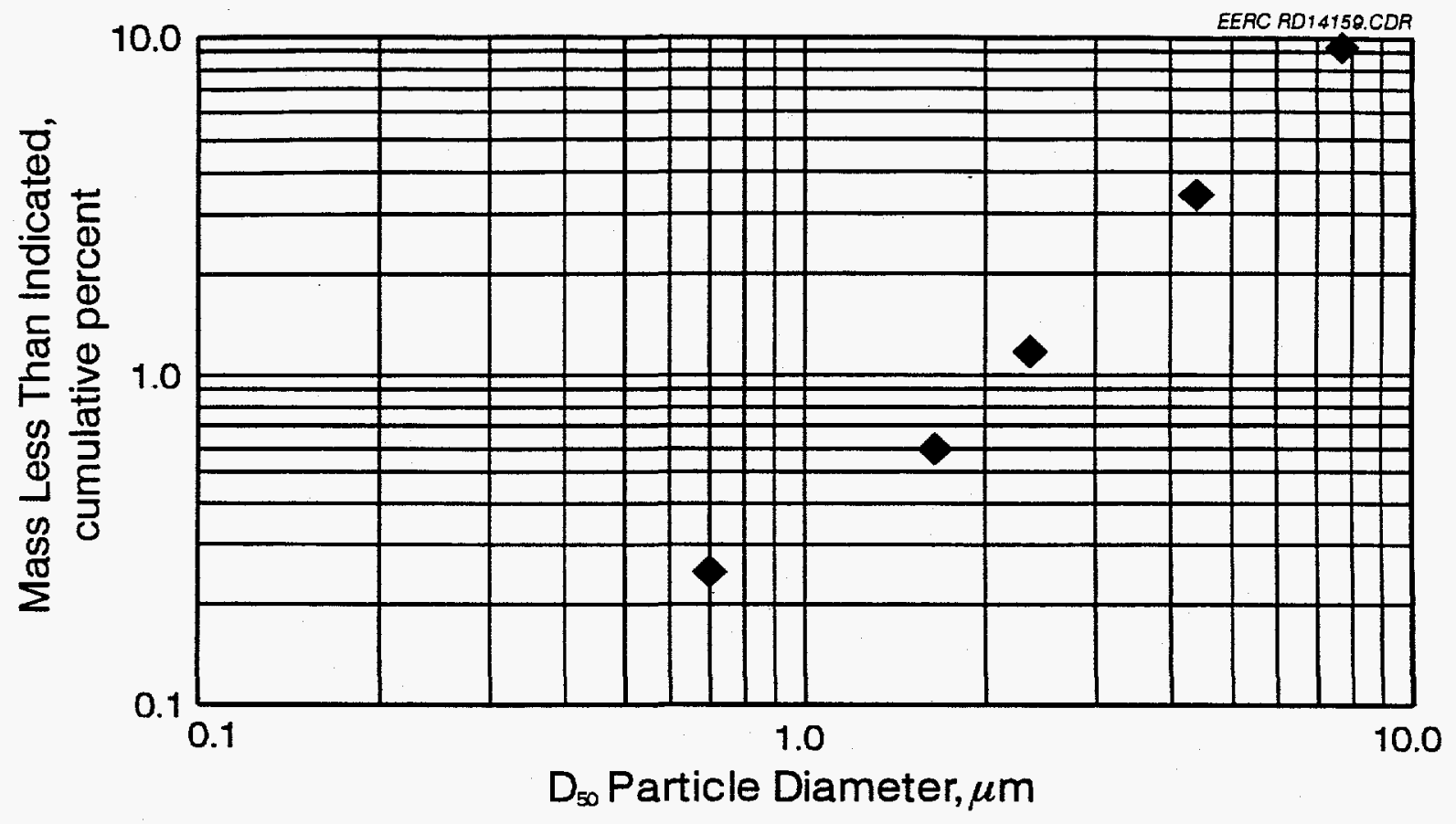

Figure 14. Inlet ESP multicyclone particle-size distribution.

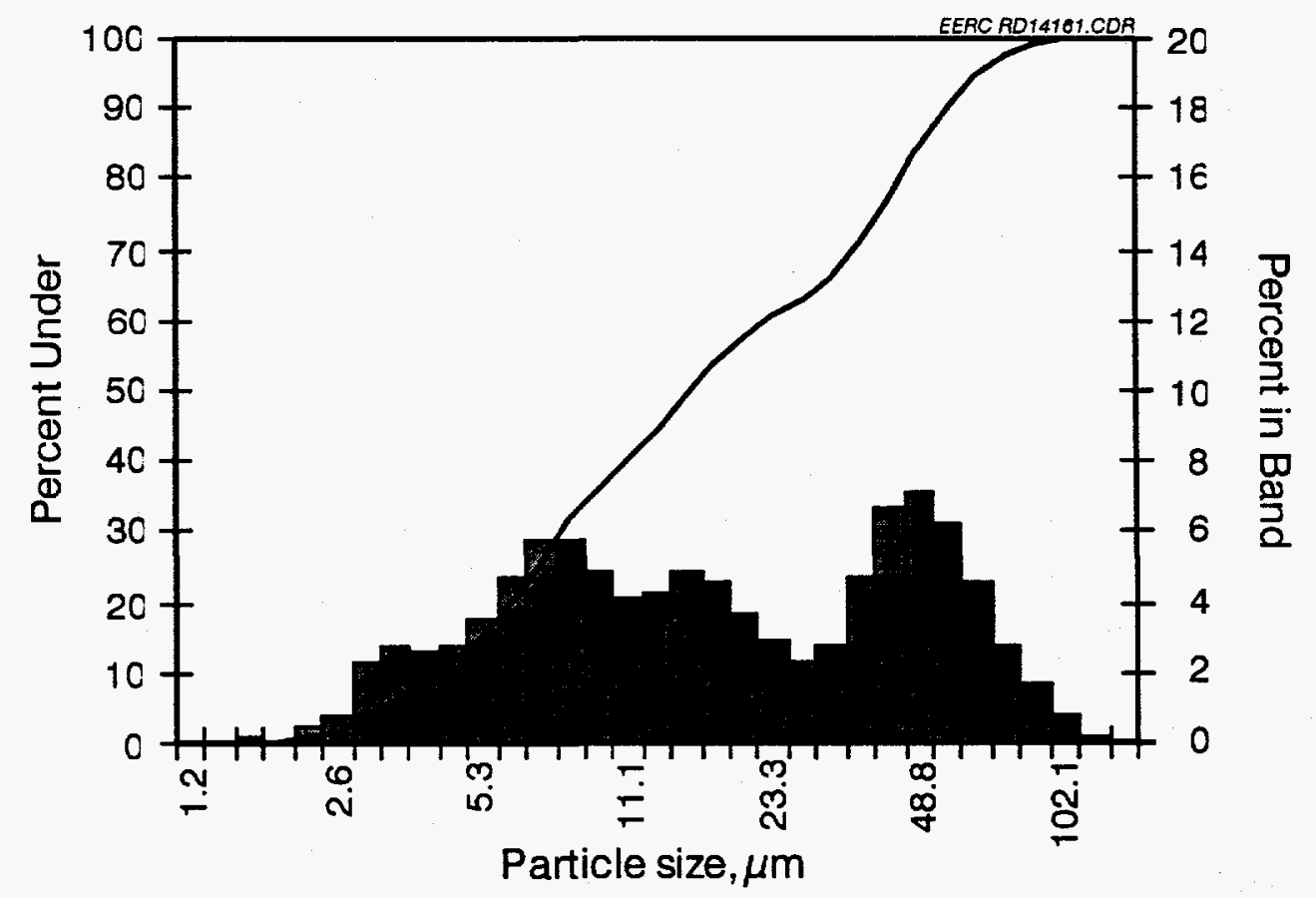

Figure 15. ESP collection hopper ash Sample No. 1 particle-size distribution. 
The concentrations of $\mathrm{O}_{2}, \mathrm{CO}_{2}, \mathrm{SO}_{2}$, and $\mathrm{NO}_{x}$ were continuously monitored at a port located just after the probe bank (Sample Port No. 1). The concentrations of $\mathrm{O}_{2}, \mathrm{CO}_{2}$, and $\mathrm{SO}_{2}$ were also taken upstream of the induced-draft (ID) fan (Sample Port No. 3). A flue gas leak was indicated by a high $\mathrm{O}_{2}$ percentage on Sample Port No. 3, and the high flue gas flow was traced to a flange after the ESP. The flange was tightened and the leakage was reduced by about $22 \mathrm{scfm}$. This leak was after the outlet sampling port, so it affected only flue gas flow and gas analyzer readings and not dust-loading results.

As the CWF's sulfur concentration was too high to be measured with the $\mathrm{SO}_{2}$ analyzers, nitrogen was used to dilute the flue gas sample flow to the $\mathrm{SO}_{2}$ analyzers. Mass flow controllers were installed in the $\mathrm{SO}_{2}$ sample lines to regulate the nitrogen flow to one-half of the total flow. Thus actual $\mathrm{SO}_{2} \mathrm{ppm}$ concentrations were twice that indicated on the data sheets. The chart recorder scale was changed to a $0-10,000-\mathrm{ppm}$ range to account for this correction. The $\mathrm{SO}_{2}$ average of $6252 \mathrm{ppm}$, reported in Table 10 , reflects the corrected concentration. The calculated $\mathrm{SO}_{2}$ concentration of $8347 \mathrm{ppm}$ on a dry basis was higher than the 6252-ppm average from the test. This difference could be due to a number of factors, including $\mathrm{N}_{2}$ dilution errors, $\mathrm{SO}_{2}$ scrubbing in the sample conditioner, and the formation of sulfates.

\section{CHAPTER 3. CONCLUSIONS}

- Hot-water drying decreased the equilibrium moisture content of Sin Pun lignite by $40 \%$.

- In comparison to raw coal slurry, hot-water drying increased the solids loading concentration of fuel samples by $10 \%$.

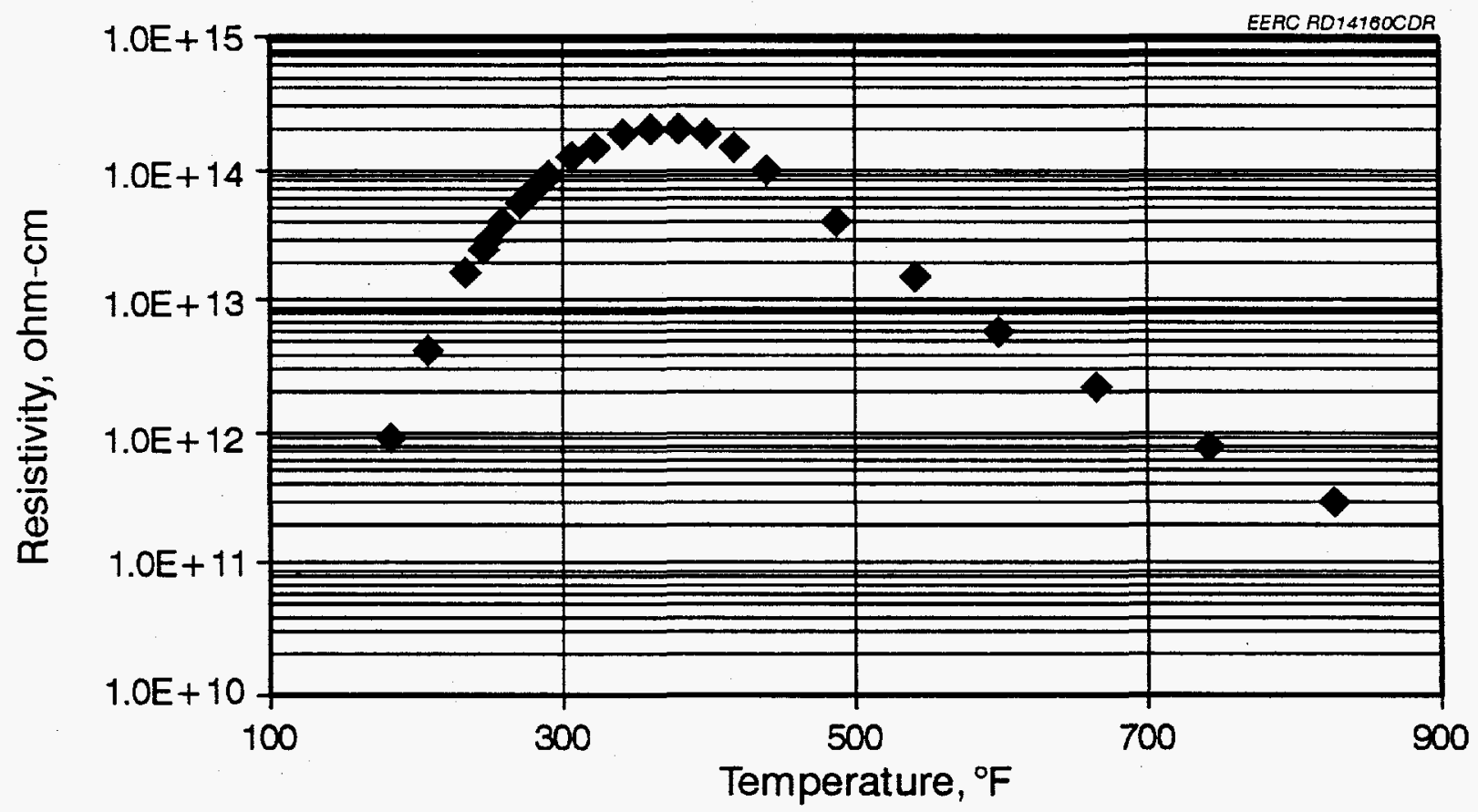

Figure 16. Sin Pun CWF ash resistivity. 
- Hot-water drying enhanced the energy density of a pumpable Sin Pun CWF by $35 \%$.

- Approximately $360 \mathrm{~kg}$ of HWD CWF was successfully produced using the pilot-scale system.

- The CWF exhibited good atomization properties and burned well in the CTF with good flame stability and reactivity.

- The ash formed from this fuel exhibited weak fouling deposits because of the quartz and iron oxides or spinels that dominated the deposits. The fuel was apparently rich in quartz and possibly iron oxide or iron/aluminum hydroxide.

- High viscosity calculations for liquid phases in the CTF convective pass fouling deposits verified visual examination of low fouling propensity. These deposits should be easily soot-blown if they are formed in temperature regions less than $2050^{\circ} \mathrm{F}\left(1121^{\circ} \mathrm{C}\right)$.

- The CWF had a high as-fired $\mathrm{SO}_{2}$ weight percent of 5.34 , with very little of the sulfur being associated with iron sulfides. Only $4 \%$ of this sulfur was bound with the calcium in the probe bank duct ash. If this fuel is used, some type of flue gas conditioning will be necessary.

- The ESP obtained a collection efficiency of only $89 \%$, possibly due to high flows through the ESP and high resistivity $\left(1 \times 10^{14}\right.$ at $\left.150^{\circ} \mathrm{C}\right)$ of the ash.

- Particle-size analysis of the ESP ash shows that $37 \%$ of the ash collected was below $10 \mu \mathrm{m}$. Only $1.4 \%$ of the ash was less than $2.6 \mu \mathrm{m}$, which would suggest that the submicron ash was not collected in the ESP, thus accounting for the low collection efficiency.

\section{CHAPTER 4. REFERENCES}

1. Davidson, R.M., Ed. Organic Sulfur in Coal; IEA Coal Research: London, 1993.

2. Sour-Gas Processing and Sulfur Recovery; The Petroleum Publishing Company: Tulsa, OK, 1979.

3. Howe, W.C.; Nakorn, S.; Philipp, J.; Mann, M.D. "Feasibility of Integrating FBC Technology at a Mine-Mouth Lignite-Fired Power Station in Thailand," Presented at the $3^{\text {rd }}$ International Conference on the Effects of Coal Quality on Power Plants, San Diego, CA, Aug. 25-27, 1992.

4. Combustion Fossil Power Systems; Combustion Engineering, Inc., Windsor, CT, 1981.

5. Bickelhaupt, R.E., "A Study to Improve a Technique for Predicting Fly Ash Resistivity with Emphasis on the Effect of Sulfur Trioxide," Windsor, CT, 1981. 
APPENDIX A

\section{ANALYTICAL EQUIPMENT AND PROCEDURES}




\section{ANALYTICAL EQUIPMENT AND PROCEDURES}

The Energy \& Environmental Research Center (EERC) has researched numerous drying and conversion technologies that can be applied to coal and subbituminous coals to upgrade the quality of the coal. Table A-1 summarizes the test procedures used to analyze the coal samples for this project.

\section{TABLE A-1}

Analytical Equipment and Procedures

\begin{tabular}{|c|c|c|}
\hline Analysis & Equipment & Procedure \\
\hline Hot-Water Drying & 2-gallon autoclave and PDU & $\mathrm{NA}^{1}$ \\
\hline Fuel Viscosity & Haake ${ }^{\circledR} 100$ rotoviscometer & NA \\
\hline Static Stability & Rod penetrometer & \\
\hline Particle Size & Malvern ${ }^{\otimes} 2600 \mathrm{c}$ laser Diffraction Analyzer & NA \\
\hline Gas Analysis & Hewlett-Packard ${ }^{\circledR 880 a}$ gas chromatograph & \\
\hline Carbon & Leco ${ }^{\circ}$ CHN 600 analyzer & NA \\
\hline Hydrogen & Leco $^{\otimes}$ CHN 600 analyzer & NA \\
\hline Nitrogen & Leco $^{\circledR}$ CHN 600 analyzer & NA \\
\hline Sulfur & Leco induction furnace & ASTM D3177 \\
\hline Sulfur Forms & NA & ASTM D2492 \\
\hline Equilibrium Moisture & NA & ASTM D1412 \\
\hline Moisture & Fisher coal analyzer & ASTM D3175 \\
\hline Volatile Matter & Fisher $^{\circledR}$ coal analyzer & ASTM D3175 \\
\hline Ash & Fisher ${ }^{\circledR}$ coal analyzer & ASTM D3174 \\
\hline Ash Characterization & Kevex energy-dispersive $\mathrm{x}$-ray spectrometer & NA \\
\hline Combustion Behavior & Drop-tube furnace (DTF) & NA \\
\hline
\end{tabular}

${ }^{1}$ Not applicable.

\section{PROXIMATE AND ULTIMATE ANALYSIS}

Proximate analysis (moisture, ash, volatile matter, fixed carbon) was performed on the raw and treated coal using a Fisher ${ }^{\star}$ coal analyzer. The instrument determines moisture at conditions specified in American Society for Testing and Materials (ASTM) Method D3175. Volatile matter is determined by heating the dried sample to $950^{\circ} \mathrm{C}$ in a nitrogen atmosphere at conditions specified in ASTM D3175. The sample is covered during this process in order to exclude oxygen and prevent the sample from being ashed. Following the volatile matter determination, the sample is 
uncovered and combusted, and the ash is determined at conditions specified by ASTM D3174. Fixed carbon is determined by difference, following the previously described methods.

Ultimate analysis determines carbon, hydrogen, nitrogen, sulfur, oxygen, and ash content in a sample. Carbon, hydrogen, and nitrogen (CHN) content are determined using a Leco ${ }^{\circledR} \mathrm{CHN}-600$ analyzer. Carbon and hydrogen are determined by infrared cells, and elemental nitrogen is measured by a thermal conductivity cell. This method gives the total percentages of CHN in the organic sample as analyzed and includes the carbon in carbonates and the hydrogen in the moisture and in the water of hydration of minerals. Sulfur is determined using a Leco ${ }^{\circledast}$ SC-132 sulfur analyzer in which a sample is combusted in oxygen, forming sulfur dioxide, which is determined by an infrared cell detector. Ash is determined by the ASTM method described under proximate analysis. Oxygen is determined by difference in order to achieve a balance of the ultimate analysis. Forms of sulfur are determined according to ASTM D2492. Ash characterization is determined using X-ray fluorescence techniques using the equipment in Table A-1.

\section{RHEOLOGICAL CHARACTERIZATION}

The rheological properties are determined based on the Yield Power Law equation for fluids. The Haake ${ }^{\circledR}$ RV 100 viscometer, shown in Figure A-1, is used to measure the flow properties of various liquid fuels from shear rates of near zero to $1100 \mathrm{sec}^{1}(\mathrm{~Hz})$ over a temperature range of $4^{\circ}$ to $95^{\circ} \mathrm{C}$. Results from the Haake are logged and compiled using a computer network system. The Haake ${ }^{\circledR}$ viscometer shears the slurry in the annular space between the rotating cylinder and a stationary cup. The torque necessary to rotate the cylinder at a given speed is measured by a torsion spring. Various rotor assemblies allow the user a complete profile of the rheological characteristics. The computer indicates the independent flow behavior, viscosity, and yield stress values for the fluid as each correlates to the Yield Power Law. Rheological data are used to assess the effect of

EERC CA11559.CDR

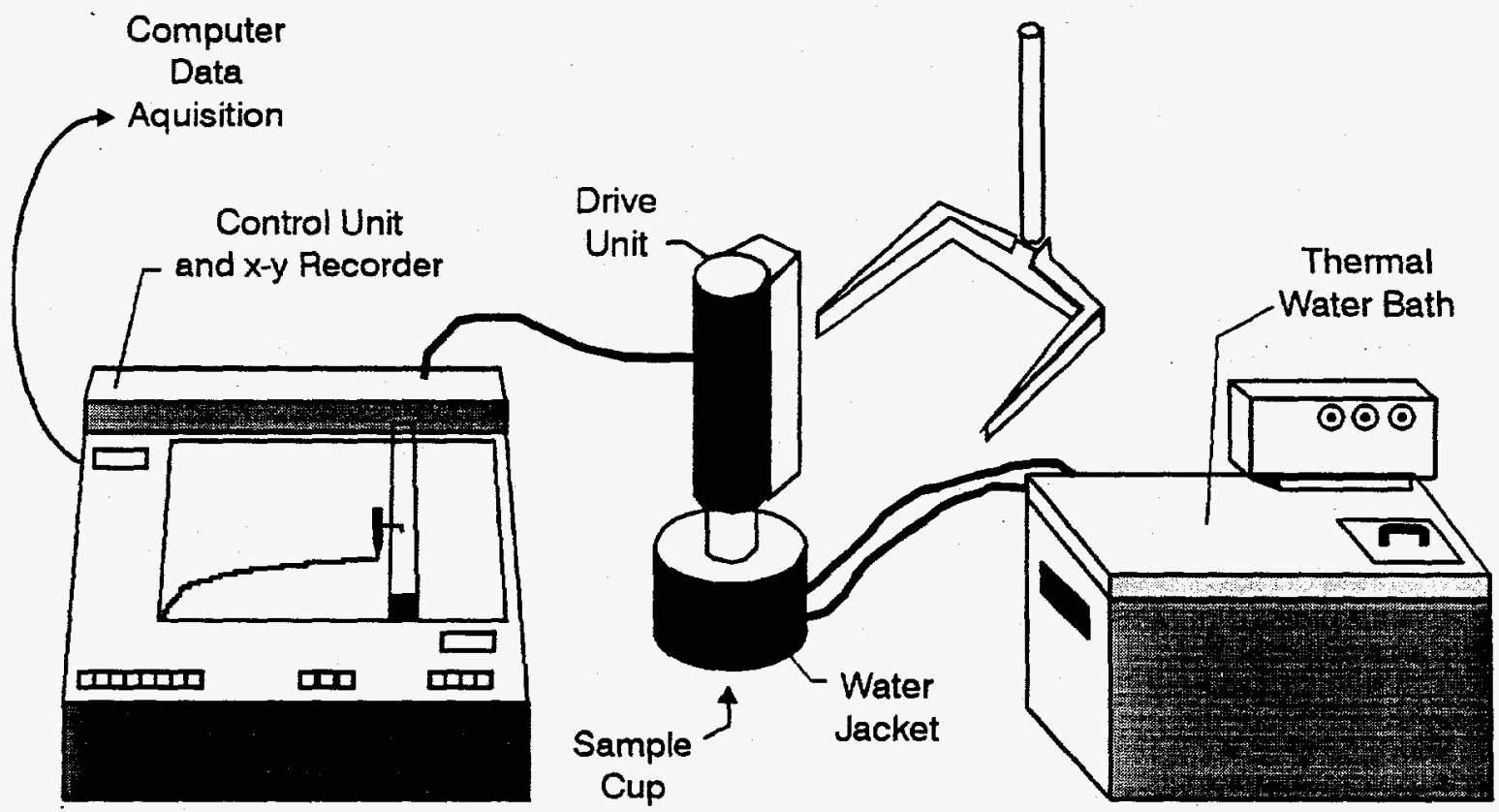

Figure A-1. HAAKE ${ }^{\otimes}$ rheological measuring equipment. 
the hot-water drying (HWD) process variables on the relationship between viscosity and dry solids concentrations.

\section{PARTICLE SIZE}

The particle-size distribution of the raw and hot-water-dried coal is determined using a Malvern ${ }^{8} 2600 \mathrm{c}^{2}$ laser diffraction particle-size analyzer, capable of measuring particle sizes from 0.5 to 564 microns. Figure A-2 depicts the Malvern instrument setup. The basic principle of the Malvern $^{(3}$ involves a He-Ne low-power visible wavelength laser that is first expanded and spatially filtered to provide a clean parallel beam. As particles pass through the beam, they scatter or diffract the light at different angles, depending upon their diameter; large particles scatter at small angles and vice versa. The scattered light is collected by a lens and brought to focus on a multielement solid-state detector that simultaneously measures the light at a number of angles. During analysis, the sample particles move rapidly through the laser beam. The results indicate the volume percentage distribution, as well as report the average particle size.

\section{EQUILIBRIUM MOISTURE}

The moisture contents of the raw and HWD coals as a function of incubation time are determined using a standard or modified ASTM equilibrium moisture method. The standard equilibrium moisture tests use an incubation time of 3 or 4 days, while the modified test uses incubation times of 2 to 30 days. The extended time period is used because the standard 3 or 4 days is often too short to allow the raw and HWD low-rank coals to attain an equilibrium moisture.

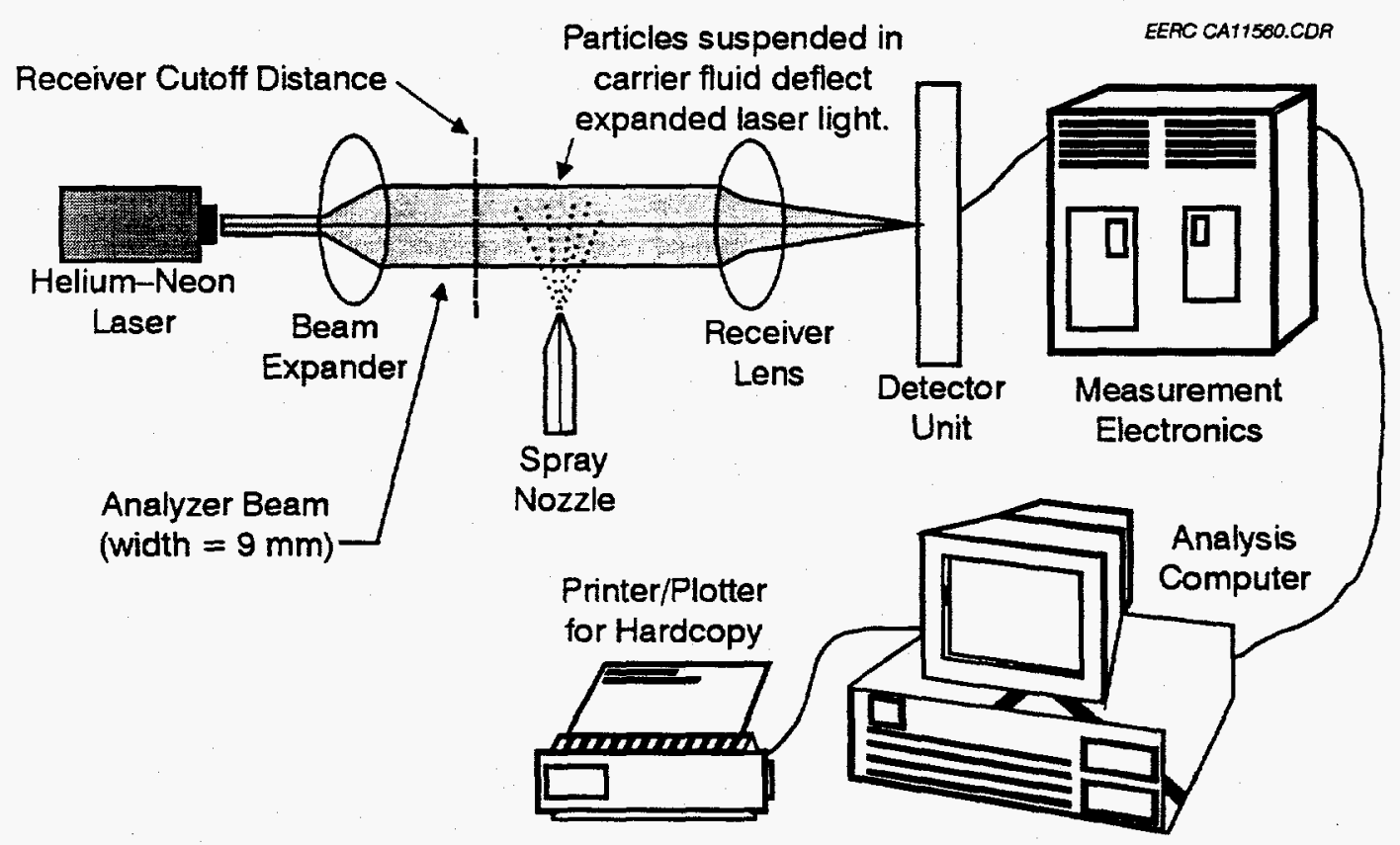

Figure A-2. Malvern ${ }^{\$}$ instrument setup. 


\section{PROCESS WATER ANALYSIS}

Various tests are performed on the process water produced during HWD to evaluate the amount of carbonaceous material, the recyclability of the stream, and treatability. The most widely used parameter of organic pollution applied to both wastewater and surface water is the 5-day biochemical oxygen demand (BOD) test. The BOD test is completed on the water sample to measure the oxygen required for the biochemical degradation of organic material and the oxygen used to oxidize inorganic material. The BOD is computed from the difference between initial and final dissolved oxygen. The chemical oxygen demand (COD) test is used to measure the content of organic matter of both wastewater and natural waters. The COD of a waste is, in general, higher than the BOD because more compounds can be chemically oxidized than can be biologically oxidized. For many types of wastes, it is possible to correlate COD with BOD. This can be very useful because the COD can be determined in 3 hours, compared to 5 days for the BOD. Once the correlation has been established, COD measurements can be used to good advantage for treatment plant control and operation. Total organic carbon (TOC), another means for measuring the organic matter present in water, is especially applicable to small concentrations of organic matter. To determine the quantity of TOC, the organic molecules must be broken down to single carbon units and converted to a single molecular form that can be measured quantitatively. TOC methods utilize heat and oxygen, ultraviolet irradiation, chemical oxidants, or combinations of these oxidants to convert organic carbon to carbon dioxide. Total carbon (TC) is determined by taking a quantity of sample and analyzing directly using an infrared carbon analyzer. In order to determine TOC, the sample must be sparged of the inorganic carbon (IC). Total solids determination is also performed on the sample. This includes total dissolved solids (TDS) and total suspended solids (TSS). TSS includes the portion of total solids retained by a filter, and TDS is the portion of the total solids that passes through the filter.

\section{GAS ANALYSIS}

Gas analysis is evaluated using a Hewlett-Packard ${ }^{\circledR}$ Model 5880a gas chromatograph with a refinery gas analyzer package used to detect selected gases in process gas samples. The method of detection is based upon relationships of thermal conductivity of the various gas compounds. The refinery package consists of five different absorbing columns and four heated valves for column switching. The instrument uses two carrier gases, and hydrogen is used for the determination of $\mathrm{CO}_{2}, \mathrm{CO}, \mathrm{O}_{2}, \mathrm{~N}_{2}, \mathrm{H}_{2} \mathrm{~S}$, and carbon chains $\mathrm{C}_{1}$ through $\mathrm{C}_{5}$ hydrocarbons. Argon is used for the determination of helium and hydrogen. 


\section{APPENDIX B}

\section{DESCRIPTION OF THE COMBUSTION TEST FACILITY (CTF) AND EXPERIMENTAL PROCEDURES FOR COAL-WATER FUEL COMBUSTION}




\section{COAL-WATER FUEL COMBUSTION \\ DESCRIPTION OF FACILITIES AND PROCEDURES}

\section{BACKGROUND}

Research programs have been under way at the Energy \& Environmental Research Center (EERC) for more than 25 years to study fouling of boiler heat-transfer surfaces in coal-fired utility boilers. A $550,000 \mathrm{Btu} / \mathrm{hr}$ pulverized coal pilot plant test furnace was constructed in 1967 to evaluate the influence of variables, including ash composition, excess air, gas temperature, and tube wall temperatures, on ash fouling. Results from this work have shown a strong correlation between ash characteristics and degree of fouling.

The research capabilities of the EERC combustion test facility (CTF) have been enhanced and expanded to provide information on a wide range of combustion-related issues. The many research applications of this pilot-scale combustion equipment over the years have included:

- Determining ash-fouling rates and the strength, composition, and structure of fouling deposits

- Applying sophisticated analytical methods to characterize input coal, ash, and deposits and to correlate coal and ash properties with deposit growth rates and strength development

- Evaluating the effectiveness of ash-fouling additives

- Studying particulate-size distribution and velocity prior to deposition on convective section heattransfer surfaces

- Evaluating combustion characteristics of coal-water slurries

- Studying high-temperature baghouse operation and performance

- Evaluating sorbent injection for $\mathrm{SO}_{\mathrm{x}}$ control

- Assessing integrated particulate and $\mathrm{SO}_{\mathrm{x}} / \mathrm{NO}_{\mathrm{x}}$ control

- Studying $\mathrm{NO}_{\mathrm{x}}$ control using selective catalytic reduction and disposable catalysts

- Evaluating ash slagging potential in a simulated wet-bottom firing mode

- Performing flame stability tests for comparing a particular fuel at full load and under turndown conditions

\section{COMBUSTION TEST FACILITY}

An isometric drawing of the EERC combustion test facility (CTF) is shown in Figure A-1. The furnace capacity is approximately $700,000 \mathrm{Btu} / \mathrm{hr}$ of slurry fuel firing at a rate between 95 and $115 \mathrm{lb}$ of slurry fuel/hr. The combustion chamber is 30 inches in diameter, 8 feet high, and refractory-lined. 
Although designed as a pulverized coal-fired unit with more than 700 combustion tests completed to date, more than 200 combustion tests firing slurry fuels have been performed on coals of varying rank.

When slurry fueis are fired, the bottom of the combustion chamber is replaced to accommodate a burner with adjustable, secondary air swirl vanes. The slurry is pumped from a continuously stirred storage tank through the burner gun to the atomizer, where it mixes with atomizing air prior to entering the burner throat (see Figure A-2). A schematic of the atomizer used during combustion of slurry fuel is presented in Figure A-3. Heated primary air carries the atomized slurry out of the burner gun, while heated secondary air is introduced in an annular section surrounding the burner gun. Heated tertiary air is added through two tangential ports located in the furnace wall about 1 foot above the burner cone. The percentages of the total air used as primary, secondary, and tertiary air are usually 10,65 , and 25 , respectively. Flue gas passes out of the furnace into a 10-inch-square duct that is also refractory-lined. Located in the duct is a vertical probe bank designed to :imulate superheater surfaces in the convective pass of a utility boiler.

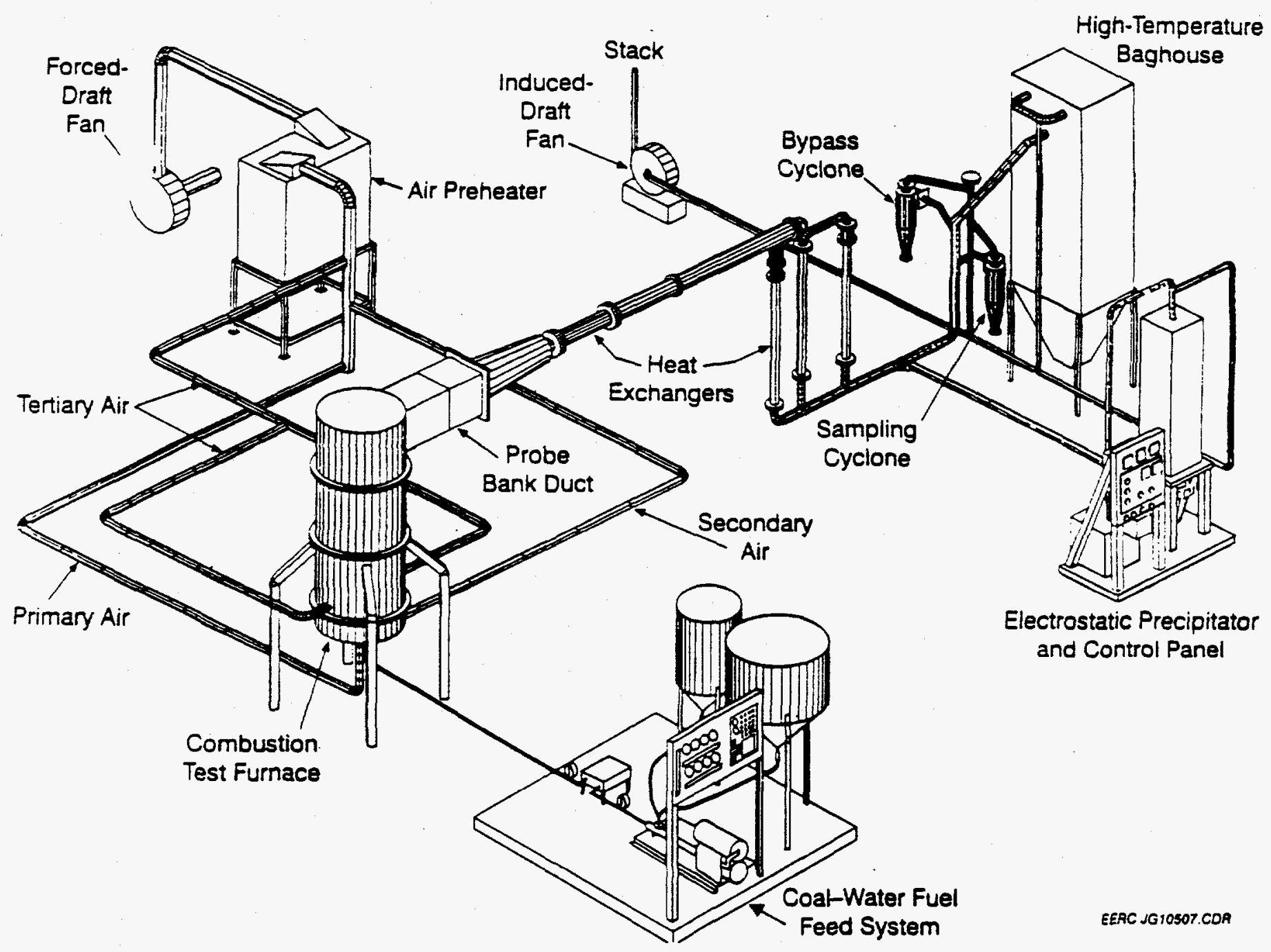

Figure A-1. Slurry-fired test combustor and auxiliary systems. 


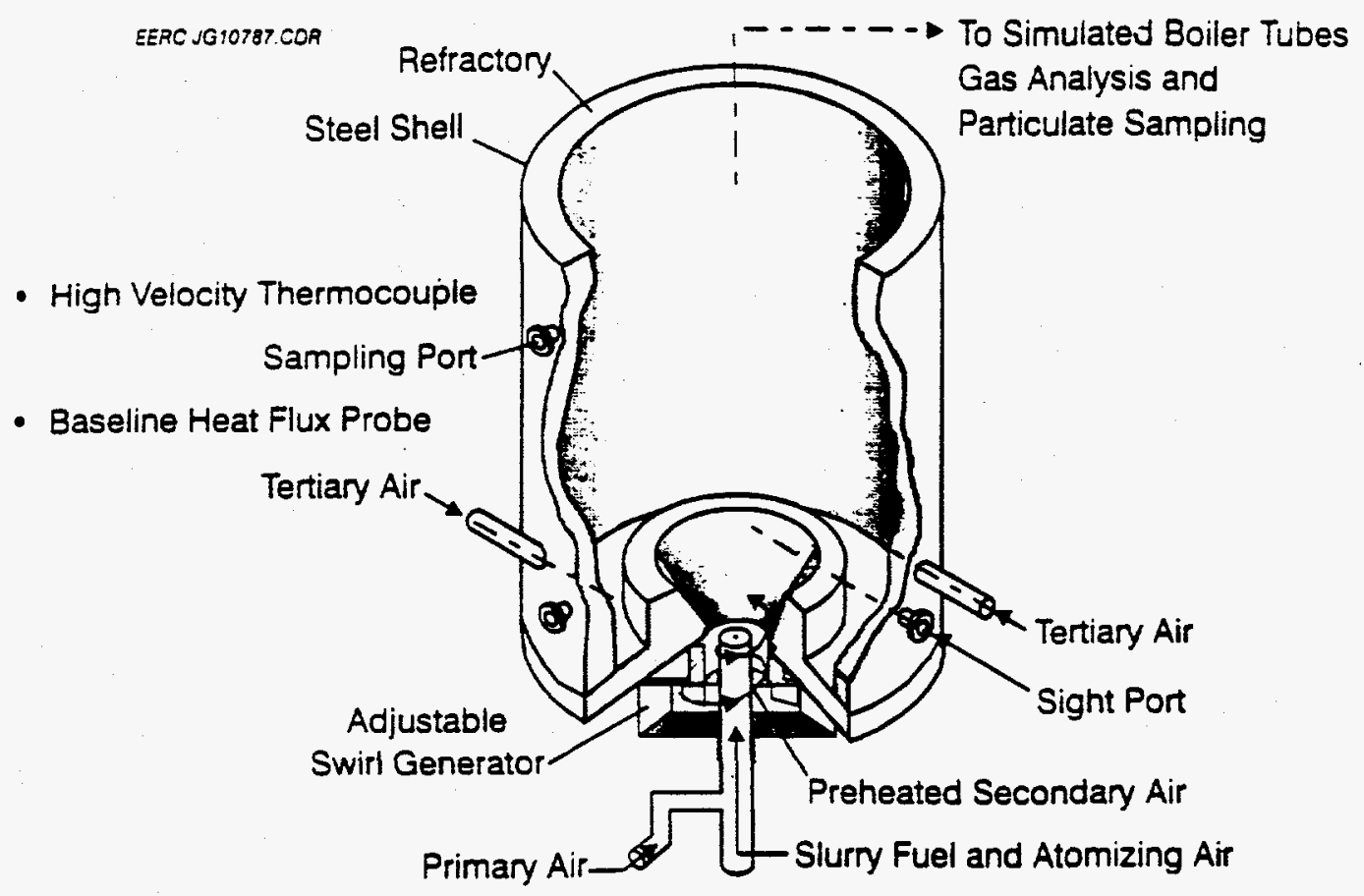

Figure A-2. Schematic of combustion test furnace.

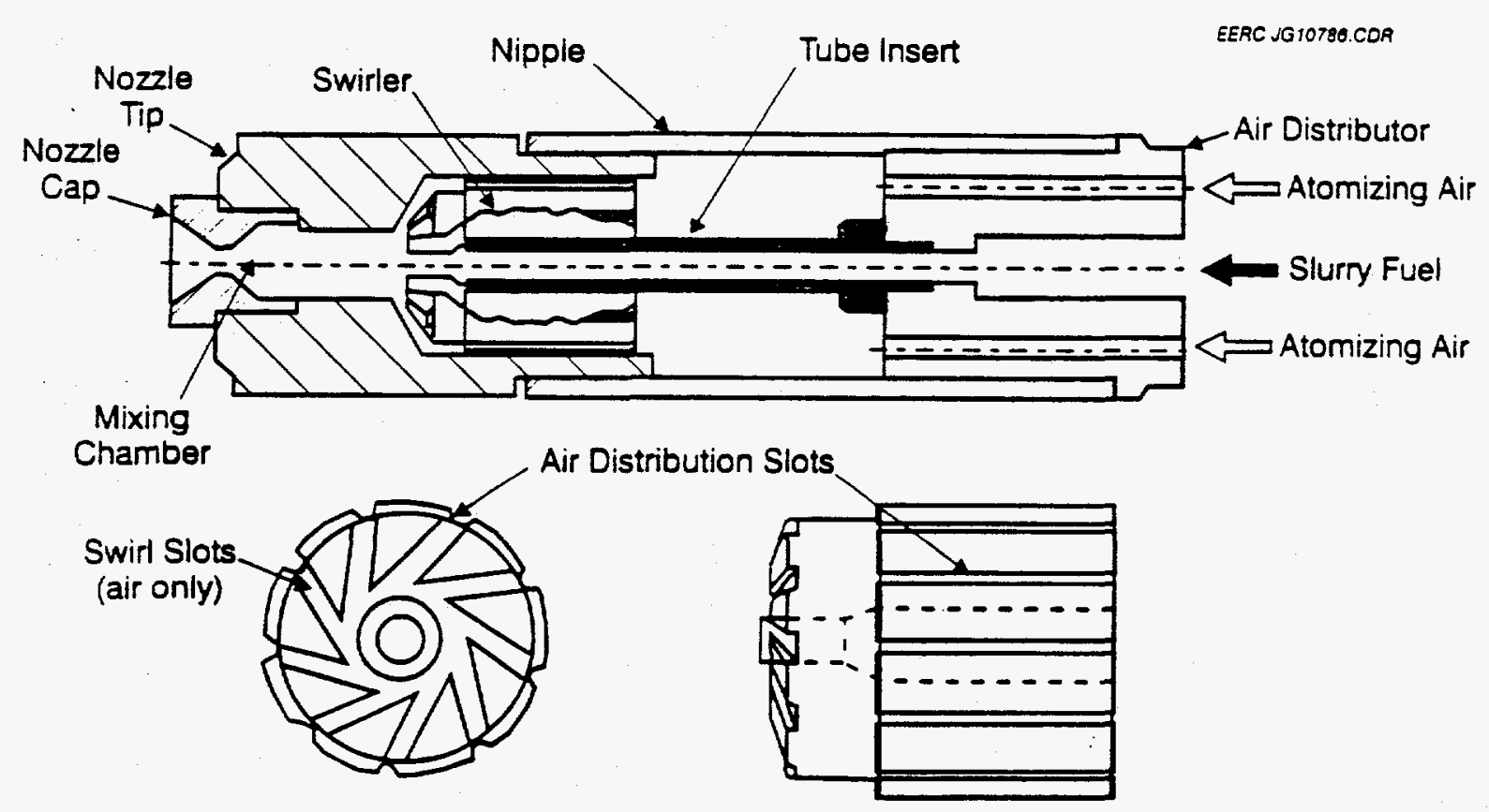

Figure A-3. BII atomizer used during combustion testing of slurry fuel. 
The furnace is fired at a rate sufficient to maintain the furnace exit gas temperature at a constant level (usually $2000^{\circ} \mathrm{F}$ or $2200^{\circ} \mathrm{F}$ ), with excess air maintained at a specified level (usually $20 \%$ or $25 \%$ excess air). The slurry fuel feed rate and air flow rates are adjusted accordingly to maintain these operating conditions. Upon leaving the probe bank duct, the flue gas passes through a series of watercooled heat exchangers used to control the temperature entering the particulate control device (either an electrostatic precipitator [ESP] or a pulse-jet baghouse). The ESP is operated at a constant inlet gas temperature (usually specified between $300^{\circ}$ and $350^{\circ} \mathrm{F}$ ) with voltage input regulated to the highest voltage attainable without sparkover or back-corona effects (usually about $60 \mathrm{kV}$ ). ESP performance is characterized by obtaining a series of U.S. Environmental Protection Agency (EPA) Method 5 particulate samples at both the ESP inlet and outlet. The fly ash collected by the ESP is subjected to a laboratory determination of resistivity in addition to standard American Society for Testing and Materials (ASTM) analyses and advanced scanning electron microscope (SEM) analyses.

In addition to the fouling probe bank at the furnace exit, the test furnace contains numerous ports through which gas and fly ash samples may be collected, and various probes may be inserted for collection of deposits. Standard ASTM techniques and advanced laboratory and SEM techniques are utilized to analyze the various samples collected.

Figure A-4 shows the construction of the ash-fouling test probe bank, which is located in a hinged door to facilitate inspection and cleaning. The three fouling probes are constructed of 1.66-inch-OD, Type 304 stainless steel pipe and are cooled with compressed air. Each probe has two thermocouples embedded in its upstream edge to measure metal temperature. One of the thermocouples on each probe is attached to a temperature recorder/controller that regulates the cooling air to the probe. Normally, the surface temperature of each probe is maintained at $1000^{\circ} \mathrm{F}$, while the gas temperature entering the probe bank is maintained at approximately $2000^{\circ} \mathrm{F}$. When the furnace is fired in the bituminous mode, the temperature entering the probe bank has been as high as $2400^{\circ} \mathrm{F}$. The gas velocity between the tubes is normally about $25 \mathrm{ft} / \mathrm{s}$ when low-rank coals are fired.

After leaving the probe bank duct, the flue gas passes through a series of water-cooled heat exchangers before being discharged through either an ESP or a baghouse. An ESP is normally used for collection of fly ash during standard combustion tests.

\section{General Test Method}

The relative fouling potential and other tendencies of test coals are determined by burning coal samples under specified conditions. When starting with a cold furnace, the following 13.25-hour test program is normally used:

\section{Hours}

$\begin{array}{lr}\text { Preheat on gas } & 8.00 \\ 100 \% \text { slurry fuel firing } & \underline{5.25} \\ \text { Total } & 13.25\end{array}$

The slurry fuel feed rate is commonly adjusted to keep the flue gas temperature entering the upper duct to the probe bank at $2000^{\circ} \mathrm{F}$ with $25 \%$ excess air. Slurry samples are taken periodically to form a composite sample. Oxygen, carbon dioxide, nitrous oxides, carbon monoxide, and sulfur dioxide in the flue gas are continuously monitored by recording analyzers. 


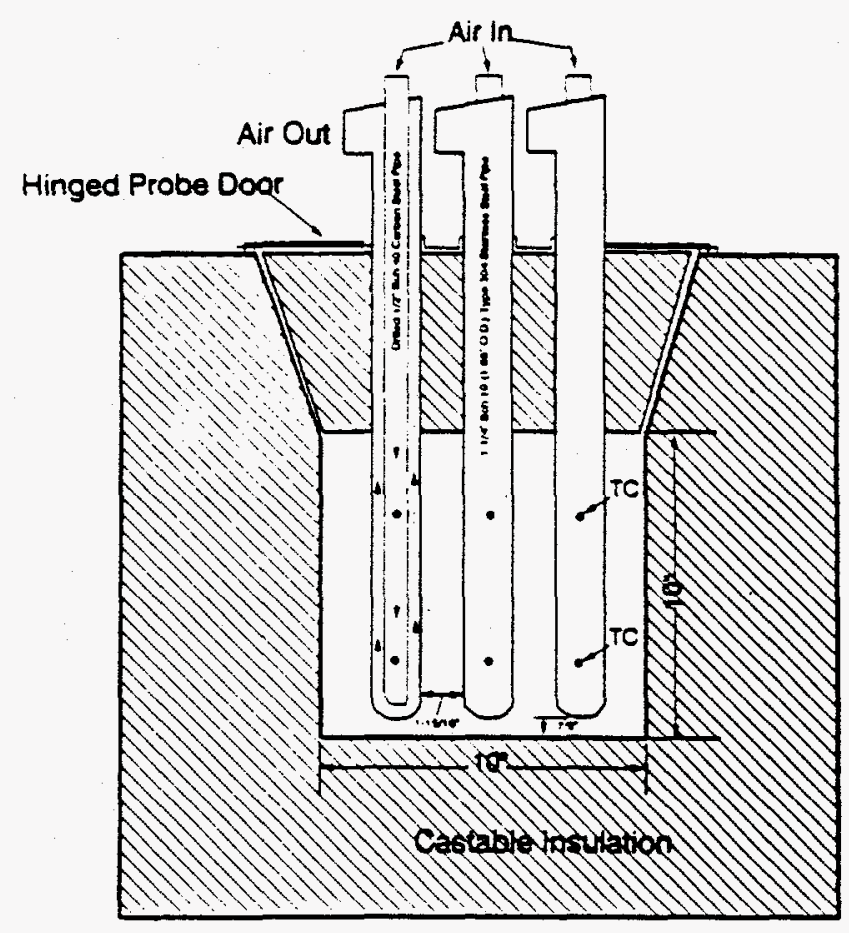

Figure $\cdot A-4$. Detail of probe bank construction.

The operating conditions and procedures described above are those normally utilized in studying the ash-fouling tendencies of low-rank western coals. They are included for the purposes of reference and description, and for comparison with the conditions actually utilized when burning slurry fuel.

The test furnace has numerous ports that permit observation of the probes and the furnace burner zone during the test run. These ports can also be used for installation of additional test probes, auxiliary measurements, photography of probes, or injection of additives.

At the completion of the test period, the probe door is carefully opened and photographs are taken of the deposit. The deposit is then removed from the probes in two fractions, an inner and an outer layer, and each is weighed and analyzed separately. Normally the inner white layer weighs less than 10 grams, as compared to 100 to 500 grams for the outer sintered deposit.

The weight of ash deposited on the probe bank during a standard test is used to rank the coal for its relative fouling potential. To ensure that the pilot-scale test results are meaningful for evaluation of ash-fouling potential in full-scale utility boilers, calibration tests were previously conducted with low-rank coals known to produce low and high fouling in utility boilers. Comparisons of ash fouling have been made based on tests conducted at a number of power stations throughout the western United States: Monticello (Texas Utilities), Big Brown (Texas Utilities), Four Corners (Arizona Public Service Company), St. Clair (Detroit Edison Company), Jim Bridger (Pacific Power and Light), Big Stone (Otter Tail Power Company), Leland Olds (Basin Electric Power Cooperative), and San Miguel (San Miguel Electric Cooperative). Based on these tests, the ash deposit buildup rate on the probe bank was found 
to be a good indicator of fouling potential. The relationship between deposit weight and a fuel's fouling potential is generally categorized as indicated below:

$\begin{array}{cc}\text { Deposit Weight. grams } & \text { Relative Fouling Potential } \\ 0-150 & \text { Low } \\ 150-300 & \text { Medium } \\ \text { Above } 300 & \text { High }\end{array}$

\section{Deposit Strength Tests}

The weight of the ash deposit from the probe bank has proven to be a good indicator of the fouling potential for most coals tested in the this furnace. Heavy deposits in the 5.25-hour test indicate high deposition rates, which can usually be related to potential ash-fouling problems in utility boilers. However, the deposition rate does not provide an indication of the ease of deposit removal by sootblowing. Methods to measure deposit tenacity and strength have been reviewed at the EERC, and strength test methods have been developed that appear to provide reliable, reproducible results.

Deposit strength is initially assessed by means of the strength rating factor (SRF). This factor is determined based on observations made by a pilot-plant operator during removal of ash deposits from the probe bank. Deposit hardness and breakability is rated from 1 to 10 , with 1 indicating soft and crumbly and 10 indicating hard and unfragmented.

The probe deposit is also subjected to a laboratory deposit strength evaluation procedure developed at the EERC, which utilized a drop impactor technique. A known weight is dropped with a measured impact on the sliced face of a 1-inch-long deposit sample. After the drop test, the sample is sieved in a sonic sifter through a series of six screens ranging in size from 5.66 to $0.21 \mathrm{~mm}$. The percentage of each size is determined and, using the procedure from the ASTM Tumbler Test (ASTM Method D44145), the dust index, friability, and mass mean diameter of the crushed deposit sample are determined. An impact resistance value (IRV) is calculated, which adjusts the results of the impactor tests for the test parameters under which they were obtained. The calculation was developed by analysis of a large body of data obtained by this procedure.

\section{Flame Stability Testing}

\section{Background}

Flame stability is assessed by observation of the flame and its relation to the burner quarl as a function of secondary air swirl and operating conditions at full load and under turndown conditions. An International Flame Research Foundation (IFRF)-type adjustable secondary air swirl generator (shown in Figure 3) uses primary and secondary air at approximately $15 \%$ and $85 \%$ of the total air, respectively, to adjust swirl between 0 and a maximum of 1.9 . Swirl is defined as the ratio of the radial (tangential) momentum to axial momentum imparted to the secondary air by movable blocks internal to the burner and is used to set up an internal recirculation zone (IRZ) within the flame that allows greater mixing of combustion air and coal. Swirl is imparted by moving these blocks to set up alternate paths of radial flow and tangential flow, creating a spin on the secondary air stream that increases the turbulence in the nearburner zone. At the fully open position of the swirl block, the secondary air passes through the swirl 
burner unaffected and the momentum of this stream has only an axial component (the air enters the combustion chamber as a jet). As the angle of the blocks changes, the air begins to spin or "swirl" and the radial component to the momentum is established, creating the IRZ in the near burner region. It is the ratio of this radial component of the momentum to the axial component that establishes the quantity defined as "swirl".

The adjustable swirl burner used by the EERC during flame stability testing consists of two annular plates and two series of interlocking wedge-shaped blocks, each attached to one of the plates. The two sets of blocks can form alternate radial and tangential flow channels, such that the air flow splits into an equal number of radial and tangential streams which combine further downstream into one swirling flow as shown in Figure 4. By simply rotating the movable plate, radial channels are progressively closed and tangential channels opened so that the resulting flux of angular momennum increases continuously, between zero and a maximum value. This maximum swirl depends on the total air flow rate and the geometry of the swirl generator. Swirl can be calculated based on dimensions of the movable blocks (the ratio of the tangential and radial openings of the blocks) or based on the measurement of the velocity of the air stream (obtaining both radial and axial components). The following description of that calculation is provided by Beer and Chigier (3).

When rotating motion is imparted to a fluid upstream of an orifice, the fluid flow emerging from the orifice has a tangential velocity component in addition to the axial and radial components of velocity encountered in non-swirling jets. The presence of the swirl results in the setting up of radial and axial pressure gradients which, in turn, influence the flow field. In the case of strong swirl, the adverse axial pressure gradient is sufficiently large to result in reverse flow along the axis, setting up the internal recirculation zone.

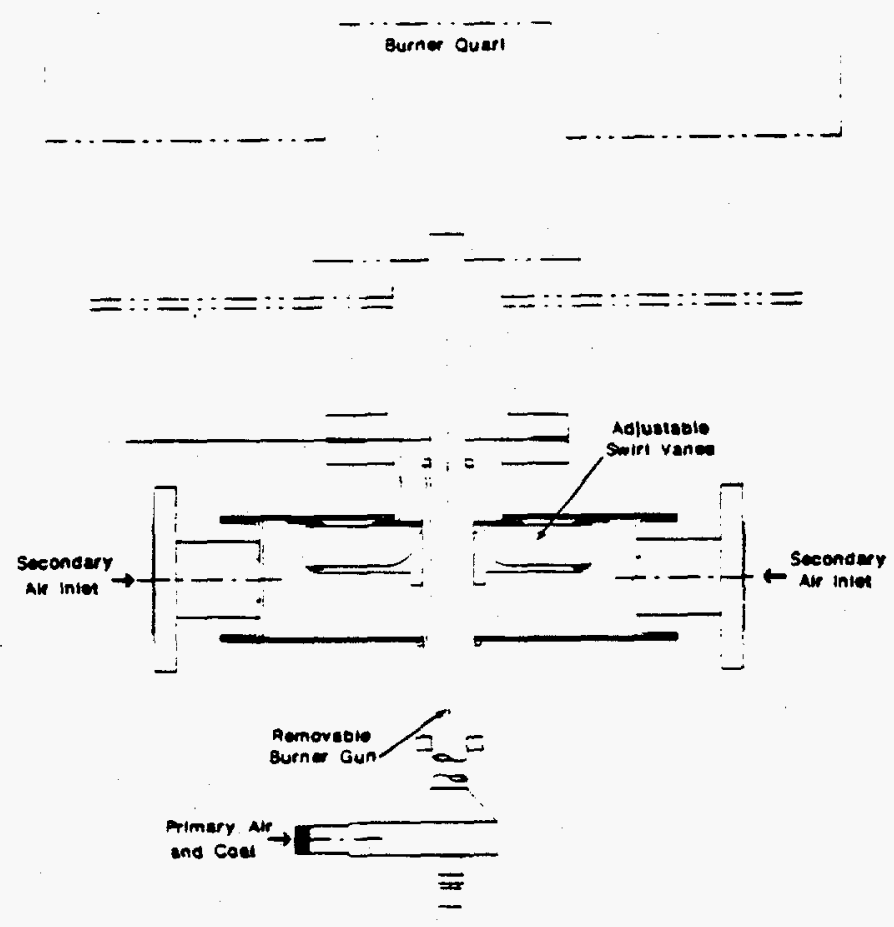

Figure A-5. IFRF adjustable swirl burner. 


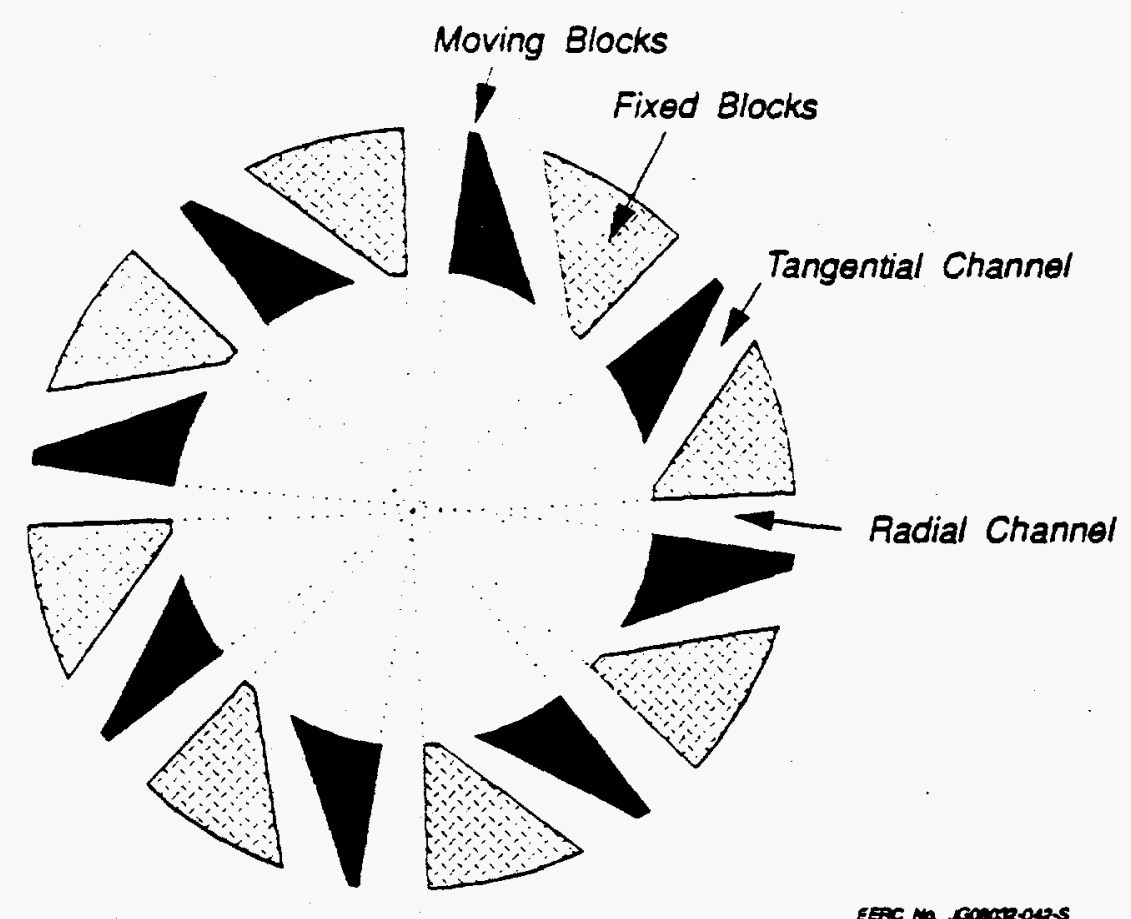

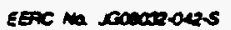

Figure A-6. Cross-section of movable block assembly.

In swirling free jets or flames, both axial flux of the angular momentum $\left(G_{\varphi}\right)$ and the axial thrust $\left(G_{x}\right)$ are conserved. These can be written as

$$
\begin{gathered}
G_{0}={ }_{0} \int^{R}\left[\left(W_{r}\right) \rho U 2 \pi r\right] d r=\text { const } \\
G_{x}={ }_{0} \int^{R}\left[U_{\rho} U 2 \pi r\right] d r+{ }_{0} \int^{R}[p 2 \pi r] d r=\text { const }
\end{gathered}
$$

where, $U, W$ and $\mathrm{p}$ are the axial and tangential components of the velocity and static pressure, respectively, in any cross section of the jet. Since both these momentum fluxes can be considered to be characteristic of the aerodynamic behaviour of the flame, a non-dimensional criterion based on these quantities can describe the swirl intensity as

$$
S=G_{\gamma} / G_{x} R \quad(R=\text { exit radius of the burner nozzle). }
$$

Experiments have shown that the swirl number $S$ was the significant similarity criterion of swirling jets produced by geometrically similar swirl generators. Other similarity criteria which take account of non-isothermal conditions and of confinement of jet flow by walls can also be applied in conjunction with the swirl number. The calculation of swirl in other types of swirl generators such as the air registers on a utility boiler are also described by Beer and Chigier (3), though not mentioned here. 
Secondary air swirl is used to stabilize the flame. In the absence of swirl, loss of flame may result. increasing the risk of dust explosion. As swirl is applied to the combustion air, coal particles are entrained in the IRZ, increasing the heating rate of the particles, leading to increased release of volatiles and char combustion. The flame becomes more compact and intense as swirl is increased to an "optimum" level, which is characterized in EERC's test facility as the point at which the flame makes contact with the burner quarl. Increasing swirl beyond this level can pull the flame into the burner region, unnecessarily exposing metal burner components to the intense heat of the flame and possible combustion in the coal pipe.

Increasing swirl to provide flame stability and increased carbon conversion can also affect the formation of $\mathrm{NO}_{\mathrm{x}}$. The high flame temperanures and increased coal/air mixing associated with increased swirl create an ideal situation under which $\mathrm{NO}_{x}$ may form. In full-scale burners with adjustable vanes, swirl is often increased to reach the "optimum" condition and then decreased slightly to reduce the production of $\mathrm{NO}_{\mathbf{x}}$.

\section{General Test Method}

The general test method sets the burner at its maximum level of swirl and monitors system parameters such as fuel feed rate, excess air, gaseous emissions $\left(\mathrm{CO}_{2}, \mathrm{CO}, \mathrm{SO}_{\mathrm{x}}\right.$, and $\left.\mathrm{NO}_{x}\right)$, combustor static, and air flow rates. Photographs of the flame and burner zone are then taken through a sight port in the furnace proper just above the burner cone using standard $35-\mathrm{mm}$ film. Flame temperature is also measured using a high-velocity thermocouple (HVT) at a set location in the furnace, and heat flux is monitored using a baseline heat flux probe at the same location. An ash sample is also collected at each swirl setting to establish carbon burnout. The swirl setting is then reduced until the flame is visually observed to lift off the burner quarl. At this point, the flame is characterized as unstable under full load conditions (between 600,000 and $650,000 \mathrm{Btu} / \mathrm{hr}$ firing rate). Photographs are again taken to record the flame at this setting, temperature and heat flux measurements are taken, and an ash sample is taken once again. Having established flame liftoff, the optimum swirl setting is then located by visual observation of the flame, and measurements are recorded once again.

Flame stability under turndown conditions is characterized by firing the test fuel at reduced load (typically one-half to three-quarter the full load rate), maintaining the same primary air flow and adjusting the secondary air flow to meet excess air requirements. The procedure described above is then used to establish flame stability at reduced load.

\section{Furnace Wall Slag Probes}

The combustion test facility (CTF) at EERC was originally designed for tests of fouling potential of low-rank coals. As a result, the nominal design values of heat input $(550,000 \mathrm{Btu} / \mathrm{hr})$, furnace exit gas temperature (FEGT $=2000^{\circ} \mathrm{F}$ ), and excess air levels $(25 \%)$ reflect utility industry experience on such fuels. More recently, efforts were made to evaluate slagging potential in the CTF. Utilizing information provided by Foster Wheeler Development Corporation, two slagging probes were designed, constructed, and positioned close to the flame region of the furnace. A simulated waterwall probe and a horizontal probe were installed just above the flame. Both slagging test probes are water-cooled to enable monitoring and maintaining surface metal temperatures between $500^{\circ}$ and $800^{\circ} \mathrm{F}$. 


\section{FLY ASH PARTICULATE CHARACTERIZATION}

Fly ash samples are obtained by various means at the inlet and outlet of the pilot-plant ESP or baghouse, as shown in Figure A-1. EPA Method 5 is used to establish particulate concentrations in flue gas. High-volume sample extraction and the pilot plant control device collection hoppers can provide larger samples for study. Particulate sizing and laboratory ash resistivity techniques used to characterize the fly ash from each test are described below.

\section{Five-Stage Cyclone System}

A five-stage cyclone system, shown in Figure A-5, is used to determine the size distribution of particulate entering the ESP. The system consists of five cyclones and a backup filter connected in series to provide five equally-spaced particle-size cuts on a logarithmic scale from 0.1 to $10 \mu \mathrm{m}$. The nominal flow rate for the system is $1.0 \mathrm{acfm}$. The five-stage cyclone system was designed to operate in-stack, but is operated out-of-stack (particulate-laden flue gas is isokinetically extracted from the stack using a sampling probe) at the EERC because of the small pipe diameters associated with the pilot-scale combustion equipment.

\section{Laboratory Resistivity Unit}

Bulk electrical resistivity measurements are made with an apparans designed and built according to the ASME Power Test Code 28 that provides control of temperature and flue gas environment for the ash samples being tested. Temperanure control is maintained by an oven consisting of two concentric cylinders separated by 3 inches of ceramic fiber insulation (Figure A-6). The outer cylinder is made of

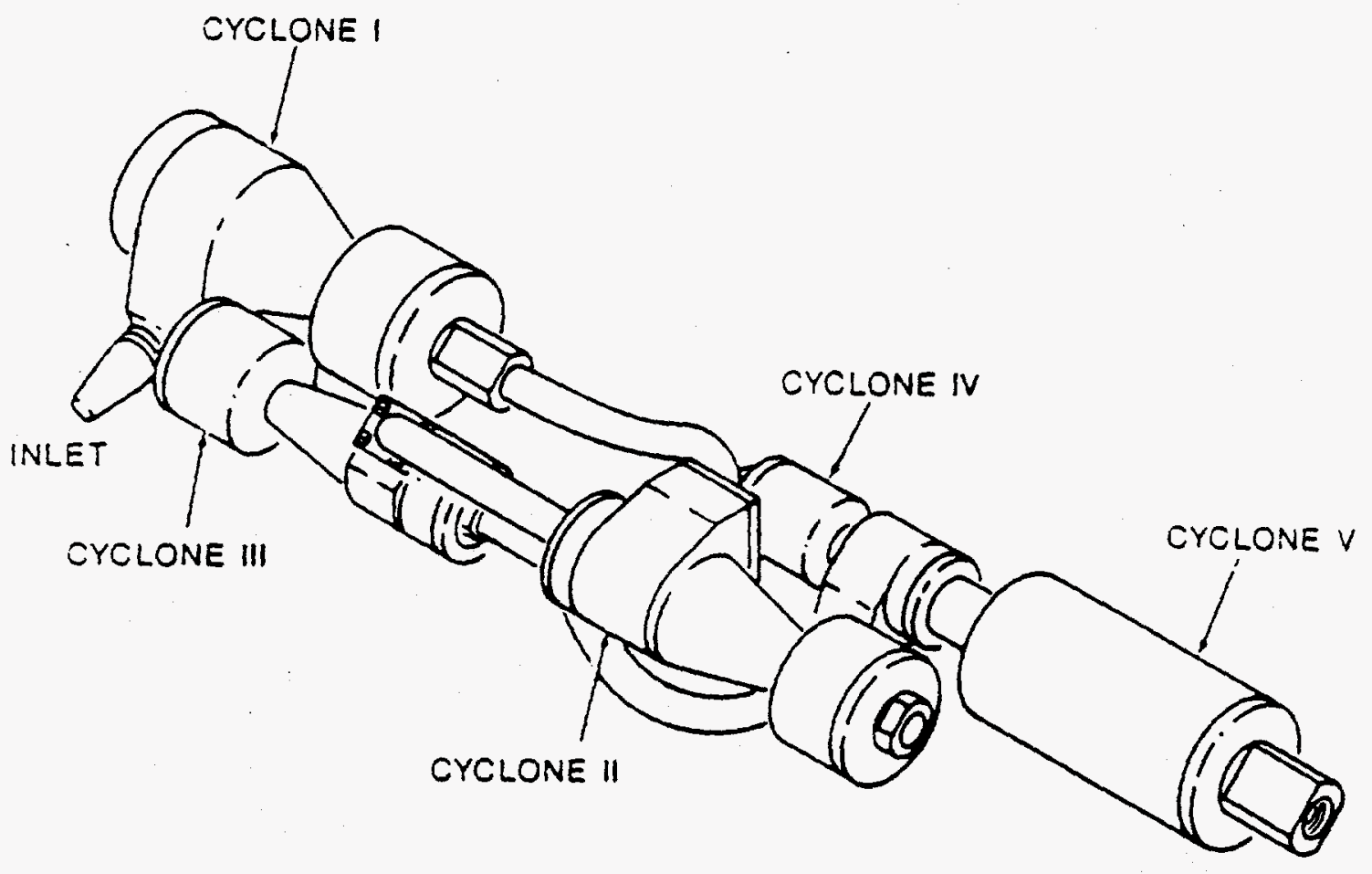

Figure A-7. Five-stage cyclone sampling system. 
mild steel and is 34 inches high and 16 inches in diameter. The inner cylinder is constructed of stainless steel and is 28 inches high and 10 inches in diameter. Heating is achieved with 3000-watt strip heaters placed around the outside of the inner cylinder. The oven can be heated to a maximum of $800^{\circ} \mathrm{F}$ in approximately $1 / 2$ hour and can maintain any temperanure between room temperature and $800^{\circ} \mathrm{F}$. Oven temperature is measured with a thermocouple, and temperature control is achieved with an automatic controller. A second thermocouple with digital readout is mounted near the ash layer for a precise determination of the oven temperature. Flue gas components $\left(\mathrm{O}_{2}, \mathrm{CO}_{2}, \mathrm{SO}_{2}\right.$, and $\mathrm{N}_{2}$ from compressed gas cylinders) are metered with rotameters to match the flue gas concentrations in which the fly ash was collected. Humidity is controlled by bubbling the simulated flue gas through a constant temperature humidification bath. Sulfur dioxide and $\mathrm{CO}_{2}$ do not go through the humidity bath, but enter the simulated flue gas stream just prior to the oven.

Fly ash resistivity measurements are made using a movable disk electrode, as shown in Figure 7. This electrode was designed to put a pressure of $10 \mathrm{~g} / \mathrm{cm}^{2}$ on a layer of ash $5 \mathrm{~mm}$ thick. The ash sample container and the electrode are made of sintered stainless steel of 25 -micron porosity to allow contact between the ash and the flue gas. The electrode can be raised or lowered by a crank on the outside of the oven.

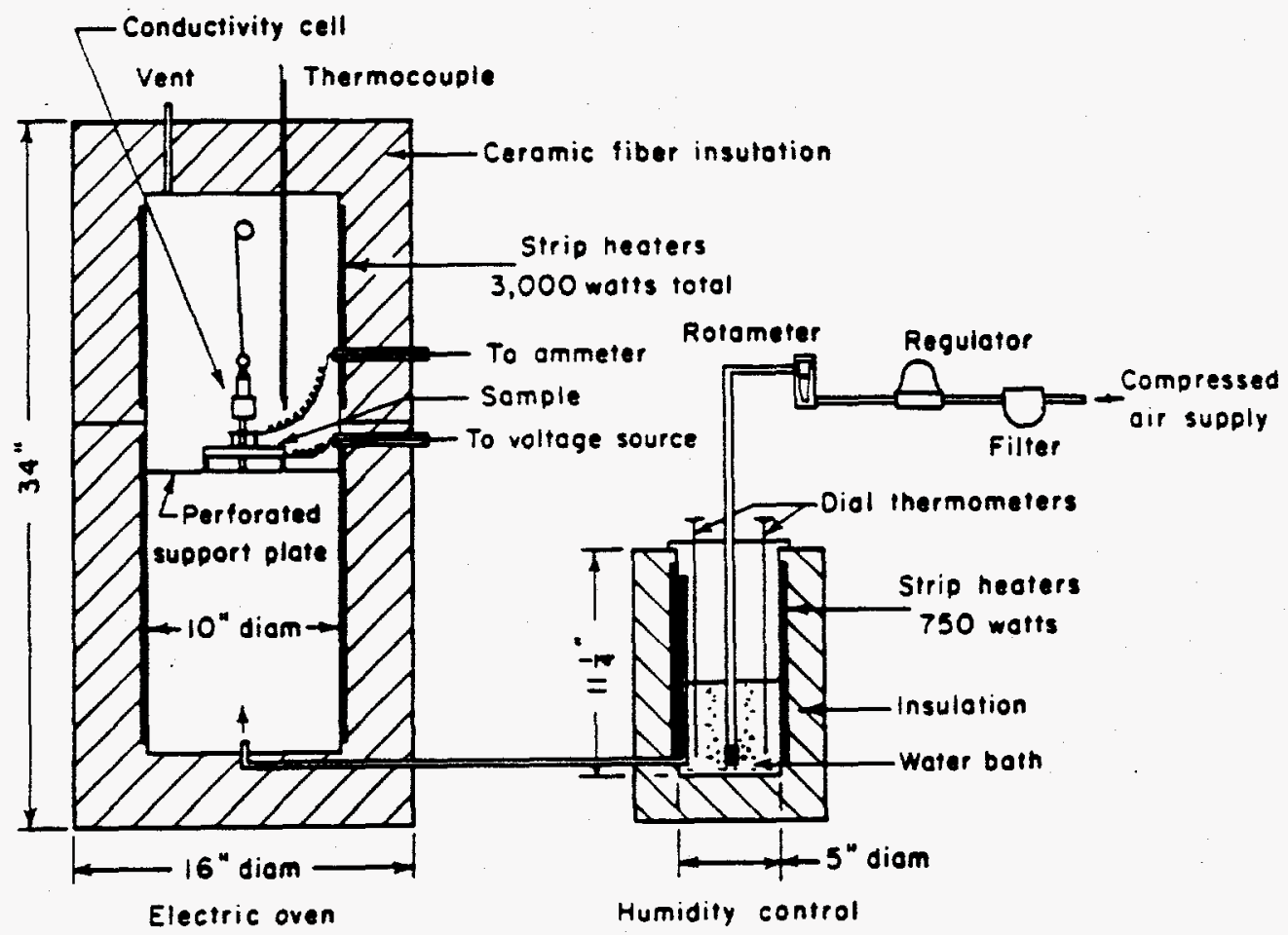

Figure A-8. Schematic of laboratory resistivity apparatus. 
A high-voltage supply with a range of 0 to 1200 volts is wired to the sample pan electrode. Current passing through the sample layer from the sample pan to the measuring electrode is measured by an electrometer capable of reading currents from $10^{-14}$ to $10^{-1}$ amperes. Coaxial cable is used on the voltage source and electrometer to shield against external noise.

A uniform ash layer is introduced to the conductivity cell and the electrode is carefully lowered onto the ash layer. The oven door is then closed and the temperature is set to $200^{\circ} \mathrm{F}$. After the oven has maintained the designated temperature for at least 40 minutes, 750 volts are applied to the $0.5-\mathrm{cm}$ ash layer. This produces a field strength of $1.5 \mathrm{kV} / \mathrm{cm}$. The current through the ash layer is measured with a high-sensitivity electrometer. The temperamre of the oven is increased to the next higher temperamu, after which there is a 40 -minute waiting period to ensure that the ash layer has a uniform temperaure. The test voltage is then applied, the current reading is recorded, and the temperature is increased to the next setting. One set of readings from $200^{\circ}$ to $750^{\circ} \mathrm{F}$ normally requires 8 to 10 hours to complete.

The fly ash resistivity (in ohm-cm) is calculated using the equation

$$
\rho=\frac{V A}{\text { IL }}
$$

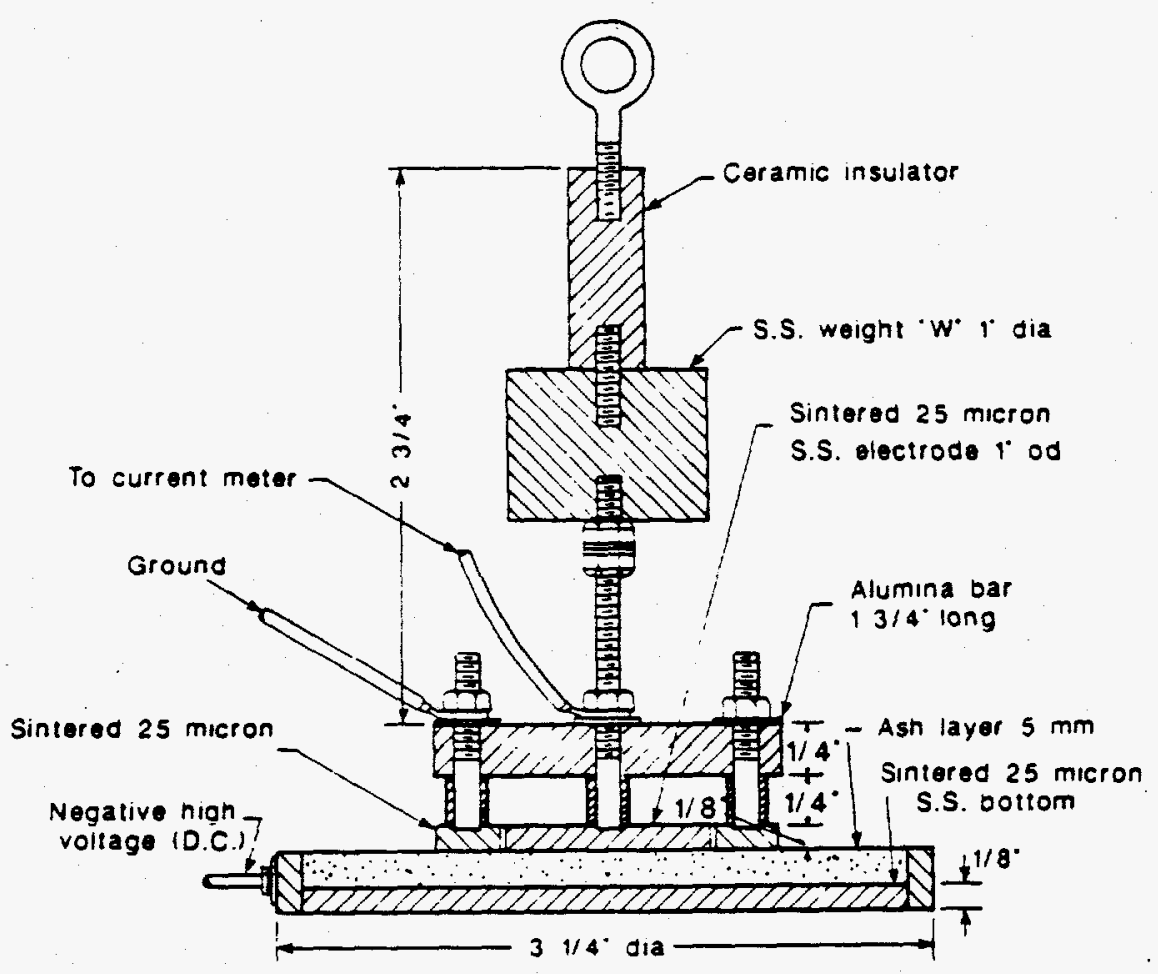

Figure A-9. Resistivity-measuring electrode. 
where $\mathrm{V}$ is the applied voltage (held constant at 750 volts), $\mathrm{A}$ is the area of the inner electrode $\left(5.07 \mathrm{~cm}^{2}\right), \mathrm{L}$ is the thickness of the ash layer $(0.5 \mathrm{~cm})$, and $I$ is the measured current in amperes. For a given test, the data are presented as a plot of fly ash resistivity in ohm-cm versus temperature.

\section{ANALYTICAL PROCEDURES}

\section{Slurry Fuel Analysis}

The slurry fuel sample is analyzed to determine its proximate and ultimate analysis, heating value, and particle-size distribution.

Proximate analysis (moisture, ash, volatile matter, fixed carbon) is performed on the raw and treated fuel using a Fisher coal analyzer. The instrument determines moisture according to the ASTM D3302-74 standard method. Volatile matter is determined by heating the dried sample to $950^{\circ} \mathrm{C}$. The sample is covered during this process in order to exclude oxygen and prevent the sample from being ashed. Following the volatile matter determination, the sample is uncovered and combusted, and the ash is determined by ASTM D3174-73. Fixed carbon is determined by difference following the previously described methods.

Ultimate analysis determines carbon, hydrogen, nitrogen, sulfur, oxygen, and ash content in a sample. Carbon, hydrogen, and nitrogen ( $\mathrm{CHN}$ ) content are determined using a Leco $\mathrm{CHN}-600$ analyzer. Carbon and hydrogen are determined by infrared cells, and elemental nitrogen is measured by a thermal conductivity cell. This method gives the total percentages of CHN in the organic sample as analyzed and includes the carbon in carbonates and the hydrogen in the moisture and in the water of hydration of silicates. Sulfur is determined using a Leco ${ }^{\oplus}$ SC-132 sulfur analyzer. It operates on the principle of determining sulfur by combusting the sample in oxygen, forming sulfur dioxide, which is determined by an infrared cell detector. The level of chlorine in the CWF is determined by ASTM method D2361. Ash is determined by the ASTM Method described above under proximate analysis. Oxygen is determined by difference in order to achieve a balance for the ultimate analysis. Forms of sulfur are determined according to ASTM-D2492-80.

Gross caloric value is measured by ASTM Method D2015 using a Paar adiabatic calorimeter and master controller.

The particle-size distribution of the fuel is determined by wet-sieve analysis according to ASTM Method D410.

\section{Inorganic and Mineral Component Analysis}

\section{Slurry Fuel Ash Anaiysis}

Concentrations of major mineral oxides ( $\mathrm{Al}, \mathrm{Si}, \mathrm{Na}, \mathrm{Mg}, \mathrm{Ca}, \mathrm{P}, \mathrm{K}, \mathrm{Fe}, \mathrm{Ti}$, and $\mathrm{S}$ ) in the fuel ash are determined by $x$-ray fluorescence. The RDF slurry ash samples are prepared using the ASTM D3174 procedure. Analysis is performed using a Kevex $x$-ray spectrometer. The elemental percentage is expressed as a weight percent of the total equivalent oxides.

Fusion temperatures of the RDF slurry ash are determined under oxidizing and reducing conditions in accordance with ASTM Method D1857 using a Preier/Mineco electric tube furnace. 


\section{Ash Deposit Characterization}

Chemical compositions of probe deposit and fly ash samples are determined by means of $x$-ray fluorescence (XRF). X-ray diffraction (XRD), which allows the identification of major crystalline forms, is used to support more quantitative SEM techniques in evaluating ash deposition phenomena. Identification, selection, and analysis of critical regions of the deposits are accomplished using SEM techniques.

A scanning electron microscopy point-count technique (SEMPC) is used to quantify the phases present in the deposit. The SEM microprobe system is a powerful tool that can be used to examine the microscopic features of deposits and fly ash and provide chemical analysis of points as small as $1 \mu \mathrm{m}$ in size. The system is automated and computer-controlled, which increases data manipulation and data storage capabilities. The SEMPC technique was developed at the EERC to systematically and quantitatively determine the distribution of phases in ash deposits and fly ash. The SEMPC technique provides information on the degree of interaction and meiting of the deposited ash components and the abundance of crystalline, amorphous, and unreacted ash particles. The data obtained from the technique are critical in identifying the components in ash deposits that are responsible for deposit growth and strength development. In addition, viscosity distribution profiles can be calculated for the amorphous or liquid phases using SEMPC data. This information provides insight into the propensity of a particular ash to form a strong deposit.

The procedure for SEMPC analysis involves preparing a cross section of the sample by mounting the ash deposit sections in epoxy. The epoxy block is sectioned to expose the ash deposit material. The exposed section is then polished to provide a very smooth surface for examination with the SEMPC technique.

The polished sample is placed in the SEM, and a compositional analysis is obtained from a series of 250 grid points across approximately $35 \mathrm{~mm}^{2}$ of the sample. The Tracor Northern 5500 computer system differentiates between epoxy and deposit material and stores the chemical information. The stored chemical information is transferred to a microcomputer that identifies and quantifies the amorphous and crystalline components in the deposit. The crystalline components are readily identified as minerals based on chemical composition and molar ratios. The amorphous component is classified as either derived phases or unclassified material. Derived phases resemble their coal mineral precursor. Unclassified material has no crystalline structure and shows no molar ratios that conform to mineral formulas stored in the SEMPC program.

\section{Fly Ash Analysis}

The elemental oxide concentration of each sample is determined by XRF. As mentioned above, this analysis includes the major mineral oxides normally associated with fossil fuels.

The particle-size distribution of the fly ash can be determined by a number of methods. One method uses a Malvern $2600 \mathrm{c}$ laser diffraction particle-size analyzer capable of measuring particle sizes from 0.5 to 564 microns (see Figure A-8). The Malvern ${ }^{\star}$ uses a He-Ne low-power visible wavelength laser that is first expanded and spatially filtered to provide a clean parallel beam. As particles pass through the beam, they scatter or diffract the light at different angles, depending upon their diameter: large particles scatter at small angles and vice versa. The scattered light is collected by a lens and brought to focus on a multielement solid-state detector that simultaneously measures the light at a number 
of angles. During analysis, the sample particles move rapidly through the laser beam. The results indicate the volume percentage distribution, as well as report the average particle size.

Trace element analysis of the flue gas is conducted by extractive sampling of the gas stream at the inlet and exit of a particulate control device using the tentative EPA Method 29 sampling train and subsequent analysis.

Tentative EPA Method 29 (currently being established for EPA by the EERC) multimetals train is the primary sampling procedure for determining trace element concentrations in the flue gas. The impinger train consists of a series of glass impingers filled with trapping solutions ending with a final moisture trap, vacuum pump, and dry gas meter. The filter assembly and impinger train are prepared by cleaning with brushes and hot, soapy tap water. Next, the train is rinsed three times in tap water and then three times in deionized (DI) water. All glassware, including quartz and teflon parts, are soaked a minimum of 4 hours in a $10 \%$ nitric acid $\left(\mathrm{HNO}_{3}\right)$ bath. After 4 hours, the glassware and Teflon parts are removed from the acid bath and are again rinsed in DI water three times. The sampling train is dried in as contaminant-free an environment as possible. The DI water is checked periodically for trace metal contamination.

A total of six impingers are included in the train. Impingers 1 and 2 are filled with $200 \mathrm{~mL}$ of $10 \%$ hydrogen peroxide $\left(\mathrm{H}_{2} \mathrm{O}_{2}\right)$ in a $5 \% \mathrm{HNO}_{3}$ solution. All trace metals, with the exception of elemental $\mathrm{Hg}$, will be captured in these impingers. Impinger 3 is empty to prevent any mixing of the two types of trapping solutions. Impingers 4 and 5 are filled with a $4 \mathrm{wt} \%$ potassium permanganate $\left(\mathrm{KMnO}_{4}\right)$ solution in $10 \%$ sulfuric acid solution. Impinger 6 contains silica gel to ensure that the flue gas is thoroughly dried before leaving the impinger train. The actual sampling procedure is similar to EPA Method 5 in that particulate matter is collected on a quartz fiber filter; however, in Method 29, vaporphase metals that penetrate the filter are collected in the impinger solutions downstream from the filter. Analysis of trace metals in the collected samples will be performed as indicated in Table A-1. Since mercury can exist as either elemental mercury or as an oxide, special care is required in sample preparation and analysis to distinguish and quantify these forms.

To prepare a coal sample for mercury analyses, approximately $0.5 \mathrm{~g}$ of coal, $2 \mathrm{~mL}$ of $\mathrm{H}_{2} \mathrm{SO}_{4}$, and $2 \mathrm{~mL}$ of $\mathrm{HNO}_{3}$ are added to a microwave digestion vessel. The vessel is sealed, placed in the microwave, and heated to attain a pressure of 40 psi for 140 minutes. After the vessel is cooled to room temperature in an ice bath, an additional $2 \mathrm{~mL}$ of $\mathrm{HNO}_{3}$ is added. The vessel is then heated to attain a pressure of 80 psi for 70 minutes. The sample is again cooled, followed by reheating to 80 psi for 70 minutes. An additional three cycles of heating to a pressure of 100 psi for 40 minutes and subsequent cooling are performed. The final step in the procedure is heating to attain a pressure of 120 psi for 40 minutes. After the sample has been cooled, it is quantitatively transferred to a $50-\mathrm{mL}$ volumetric flask, brought to volume, and filtered.

Similarly to the coal samples, ash samples are also digested using a microwave digestion system. Approximately $0.5 \mathrm{~g}$ of ash, $3 \mathrm{~mL}$ of $\mathrm{HNO}_{3}, 3 \mathrm{~mL}$ of hydrochloric acid $(\mathrm{HCl})$, and $3 \mathrm{~mL}$ of hydrofluoric acid (HF) are added to a microwave digestion vessel. The vessel is placed in the microwave, heated to a pressure of 100 psi for 40 minutes, and then cooled to room temperarure in an ice bath. Four percent boric acid $\left(\mathrm{H}_{3} \mathrm{BO}_{3}\right)(15 \mathrm{~mL})$ is then added to the vessel, which is heated to attain a pressure of 50 psi for 20 minutes cooled and reheated. The sample is quantitatively transferred to a $50-\mathrm{mL}$ volumetric flask, brought to volume, and filtered. 
To analyze the Method $29 \mathrm{H}_{2} \mathrm{O}_{2}$ solutions, $5 \mathrm{~mL}$ of sample is transferred to a 50 -mL test tube. A sufficiently sized tube is necessary to prevent the sample from overflowing during the effervescent neutralization step. The samples are placed in an ice bath and allowed to cool for 15 minutes. To decompose the $\mathrm{H}_{2} \mathrm{O}_{2}, 0.25 \mathrm{~mL}$ of $\mathrm{KMnO}_{4}$ solution is added. After cooling for 15 minutes, the procedure is repeated four times. As a final step, an additional $2 \mathrm{~mL}$ of $\mathrm{KMnO}_{4}$ solution is added in $0.5-\mathrm{mL}$ additions to provide an excess of reagent. After each addition, the samples are cooled and agitated. As a final step, $2 \mathrm{~mL}$ of hydroxylamine sulfate solution is then added in $1-\mathrm{mL}$ additions, (cooled and agitated after each addition) to reduce the $\mathrm{KMnO}_{4}$.

For the $\mathrm{KMnO}_{4}$ solutions, solid hydroxylamine sulfate is added to the sample to reduce the $\mathrm{KMnO}_{4}$ until no color persists and the $\mathrm{KMnO}_{4}$ residue is dissolved. The sample, which is usually in a 250 - or a $500-\mathrm{mL}$ volumetric flask, is brought to volume.

Mercury analyses at the EERC are done using a commercial cold-vapor atomic adsorption (CVAA) analyzer (Leeman PS200). In this instrument, a prepared sample enters the system and is mixed with a reducing agent (10\% stannous chloride) to form elemental mercury vapor. The mixture flows into a liquid-gas separator where nitrogen is introduced to carry the mercury vapor through a drying tube for water vapor removal. The dry vapor then enters one path of a double optical cell that has been optimized for fast response time and sensitivity. A mercury source, powered by a constant current power supply, delivers a stable source of emissions at $254 \mathrm{~nm}$. Absorbance by the mercury cold vapor is measured using a solid-state detector with a wide dynamic range. The resulting signal is referenced to the simultaneous absorbance of the pure carrier gas flowing through the second optical path under identical conditions. These signals are then sent to a computer system where the mercury concentration of the solution is calculated and reported. Although $0.1 \mathrm{ppb}$ is reported as the detection limit of the instrument, EERC personnel have determined that the instrument has a credible detection limit below $0.1 \mathrm{ppb}$.

To ensure the precision and accuracy of the instrument, it is calibrated on a regular basis using quality control standards. The calibration check standards are analyzed every five samples to check for instrument drift, and every ten samples a reslope is performed. All samples are run in duplicate, and one in every ten samples is spiked to verify analyte recovery.

TABLE A-1

Trace Element Analysis of Raw and Chemically Cleaned Coal

\begin{tabular}{ll}
\hline Parameter & Instrument \\
\hline Mercury & CVAAS $^{a}$ \\
Selenium & HGAAS $^{b}$ \\
Antimony, Arsenic, Cadmium, Lead & GFAAS $^{c}$ \\
Chromium, Cobalt, Manganese, Nickel, Lead and Beryllium & ICAP-AES $^{d}$ \\
Chloride & IC $^{\bullet}$ \\
\hline
\end{tabular}

- Cold-vapor atomic absorption spectroscopy.

- Hydride generation atomic absorption spectroscopy.

c Graphite furnace atomic absorption spectroscopy.

- Inductively coupled argon plasma-atomic emission spectroscopy.

- Ion chromatography. 


\section{Analytical Equipment for Trace Element Concentration}

A description of the analytical equipment used to determine trace element concentrations follows:

- Leeman Labs PS1000 sequential ICAP atomic emission spectrophotometer with integrated computer, autosampler, and Hildebrand grid nebulizer for quantitative multielement analysis. Purged optics allows for increased analytical capabilities by expanding the wavelength coverage to a range of $178-800 \mathrm{~nm}$.

- Perkin Elmer 5100 atomic absorption spectrophotometer with heated graphite furnace atomization and Zeeman background correction. This allows for quantitative trace element analysis at the parts-per-billion level for highly complex sample matrices such as coal and coal fly ash mixed acid digestions.

- Dionex 2120i dual-channel ion chromatograph with auto sampler and conductivity, UV/Vis, and electrochemical detectors for the quantitative analyses of anions and cations at the parts-per-billion level.

- Leeman Labs PS200 automated mercury analyzer based on CVAA for the determination of mercury with parts-per-trillion sensitivity.

- Varian AA1475 atomic absorption spectrophotometer equipped with a VGA-76 vapor generation accessory and electrically heated quartz cell for the determination of hydride-forming elements such as selenium, arsenic, and antimony.

\section{Leaching Potential of HAPS (SGLP, TCLP, LTL)}

To determine the leaching potential of the HAPs captured in the fly ash, a thorough materials chemical characterization will be initiated with a qualitative screening technique. Qualitative identification of elements present is particularly helpful in determining which elements need to be evaluated for leachability. This screening step provides information on elemental constituents present in individual materials. Identifying the chemical constituents in this manner has several advantages over the use of a predetermined list of analytes. These advantages include avoiding analyses of elements not present in large enough amounts to be of concern and avoiding the omission of analyzing other elements whose presence is unexpected. The qualitative screening is followed by quantitative analysis using more sensitive techniques, such as flame and graphite furnace atomic absorption spectroscopy, inductively coupled argon plasma emission spectroscopy, ion chromatography, and other instrumental and classical analytical techniques. These techniques, coupled with appropriate dissolution techniques, will be used to determine the concentrations of the chemical constiments in the bulk materials.

The chemical characterization scheme for utilization-disposal also includes an evaluation of the leaching characteristics of the materials. Leaching characteristics are very important for environmental and health reasons, both in disposal and utilization scenarios. The leaching characterization protocol developed at the EERC includes the use of both short- and long-term leaching procedures and a 
mineralogical evaluation of the leached material following long-term leaching. The leaching procedures used can be summarized as follows:

- The toxicity characteristic leaching procedure (TCLP)

- The EPA regulatory test for hazardousness of materials to be disposed in a sanitary landfill

- Short-term ( $<48$ hours) leaching with a predefined leaching solution

- The synthetic groundwater leaching procedure (SGLP)

- Developed at the EERC

- Short-term leaching with leaching solution determined by the type of water expected to contact the used or disposed material

- The long-term leaching procedure (LTL)

- Developed at the EERC

- Long-term leaching procedure ( $>48$ hours) with leaching solution identified for the SGLP with leachate analysis at time intervals to evaluate changes in leachate quality

There are two important reasons that the TCLP alone may be inappropriate and provide incomplete or inadequate leachate characterization information. First, the TCLP utilizes an acidic solution containing acetic acid. The use of acetic acid as a leaching solution is, by EPA definition, designed to simulate the leaching a waste will undergo in a sanitary landfill. Under utilization and many disposal scenarios, the water to contact the by-product is extremely unlikely to contain acetic acid. The actual $\mathrm{pH}$ and chemistry of the leaching fluid likely to contact the by-product must be considered in order to perform a laboratory evaluation of leaching potential that will provide information pertinent to commercial applications. If it is the case that rainwater or alkaline water will be doing the actual field leaching, the solution used in the lab must exhibit a similar chemistry. Rainwater can often be simulated by a neutral solution (distilled water). The SGLP will be performed in addition to the TCLP to provide a complete and realistic evaluation of the short-term leaching characteristics of the materials selected for the study. Results of these two short-term leaching procedures will be compared and evaluated along with results of long-term leaching procedures. The use of a long-term leaching procedure addresses the second potential shortcoming of leaching evaluation by TCLP only. Combustion by-products, including fluid-bed combustion (FBC) by-products, may change mineralogical composition owing to hydration reactions upon contact with water and interaction between different minerals and constituents of the by-product or other added material in the product. These chemical reactions can have a significant impact on the leachate generated and must be considered to fairly evaluate these materials for use or disposal. Many of the reactions are slow and can take up to 30 days to exert an effect, as demonstrated by previous research projects at the EERC. The effect can be more than an order of magnitude with respect to solution concentration of several potentially hazardous elements. LTL procedures (30 and 60 days) will be used to evaluate long-term phase changes and to establish the direction of concentrations of trace elements as equilibrium is approached, providing more realistic information regarding the potential mobility of elements in a material under disposal conditions. X-ray diffraction will be performed on the original material and the leached material from long-term leaching to aid the evaluation of trace element mobility in this material. 
APPENDIX C

DATA SHEETS, OPERATORS'S LOG, AND CIRCULAR CHARTS 


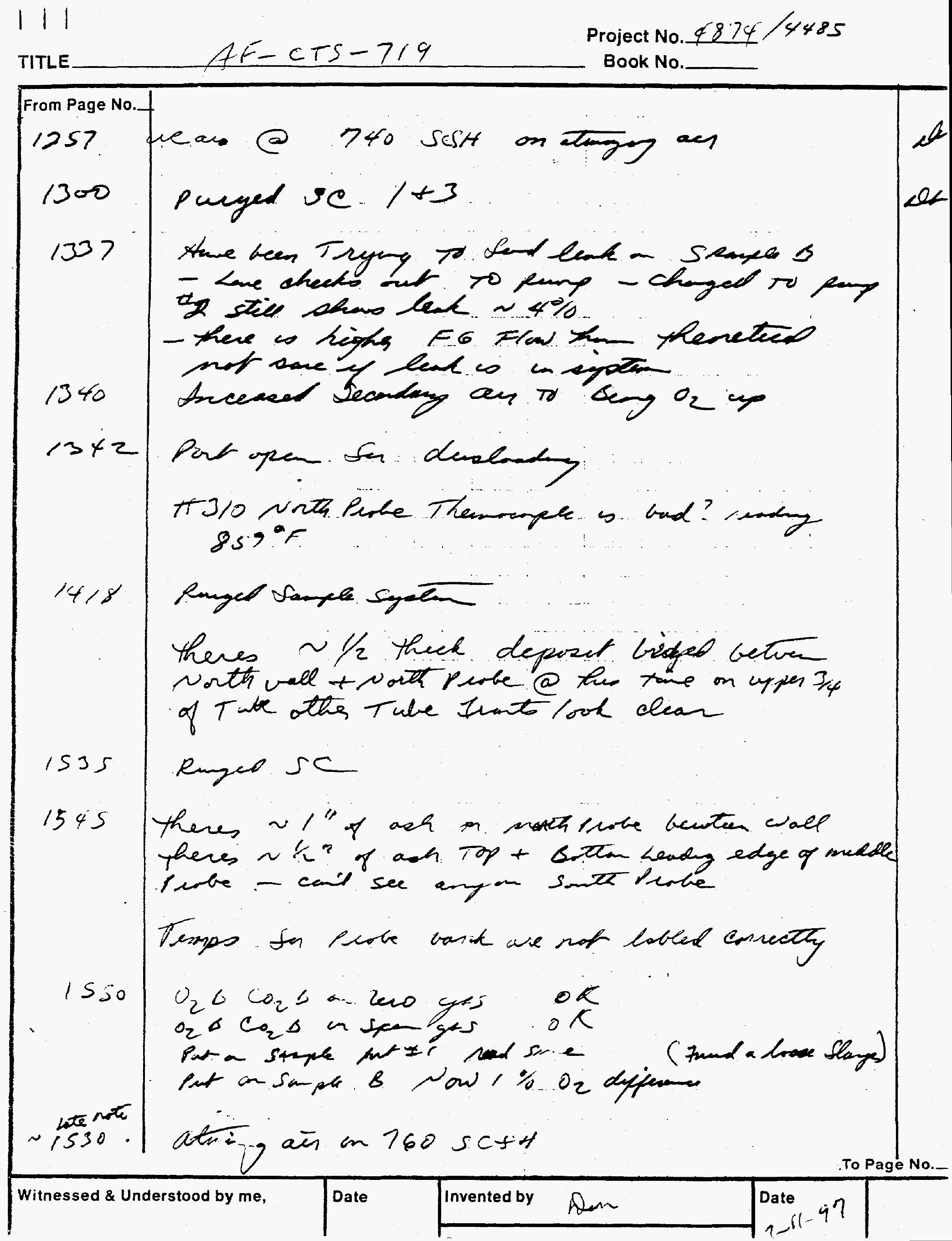




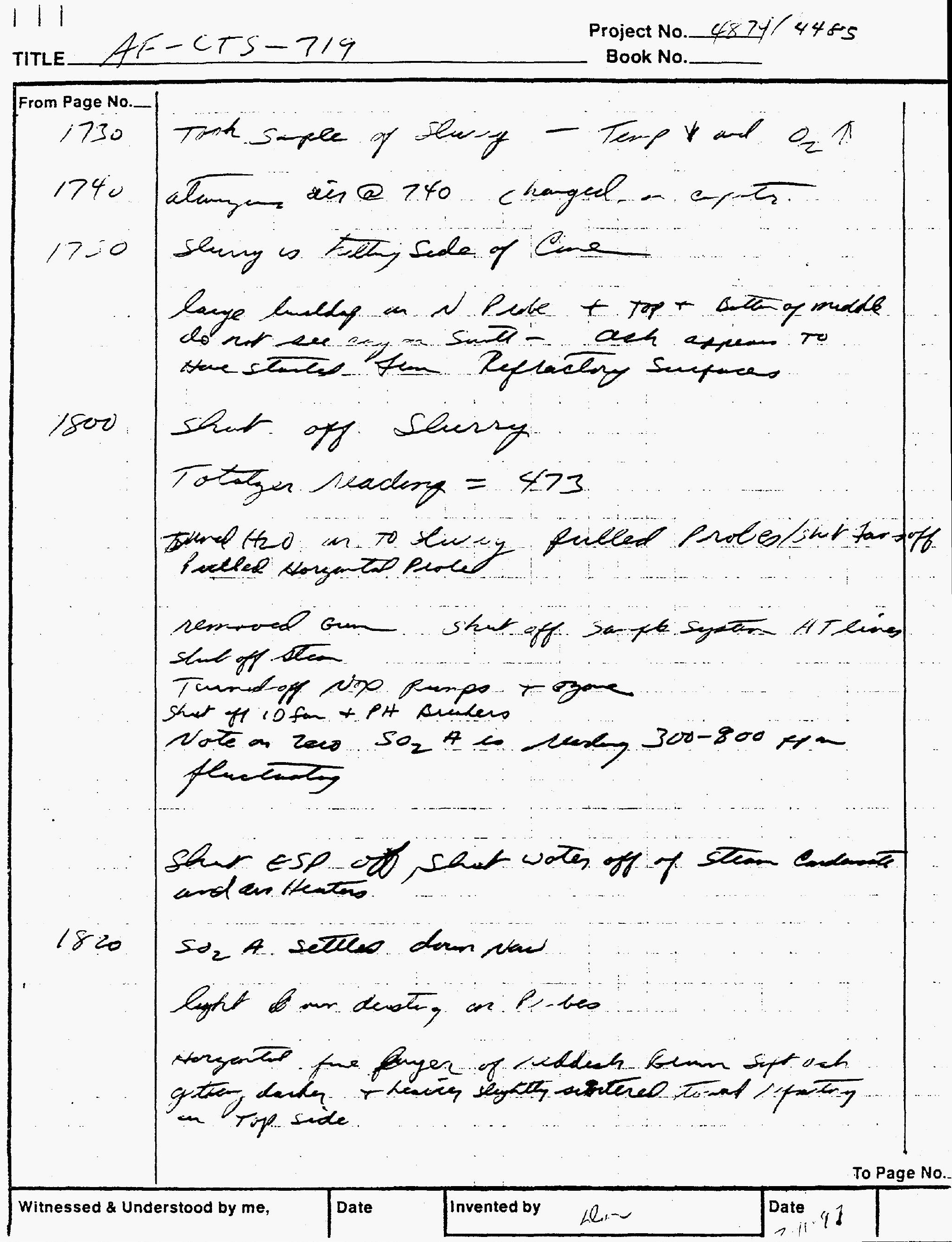


4

Book No. $\longrightarrow$ TITLE $A F-C T S-719$

om Page No._

FEED SluRRY BBL'S

$$
\begin{aligned}
& B B L^{\# 2} \quad 378^{*}+8^{*} \text { water = } 386^{\#} \text { Slurry added }
\end{aligned}
$$

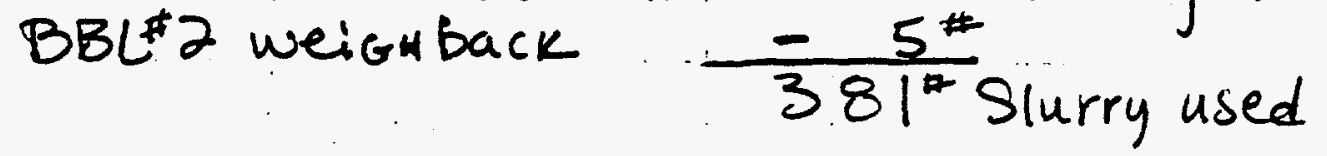

Slurry FEED RATES FROM QFTER TEST Calibrations.

O calibration test o ware Done

Actual Rote $15.8 \% /$ He

\#2 Actual Rate 1/7,0\#/H e
Mickomotion

$83^{*}-84^{*} / A R$

$85-86^{*} / 4 \mathrm{~K}$

witnessed \& Understood by me,

To Page No.

Date

Invented by

Date

Recorded by 
111

Project No. $4445 / 4874$

TITLE

Book No.

From Page No.

71.0 gn Duk ash on Hoymat Proce (sopt sutwes)

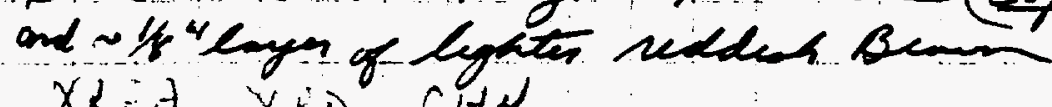
XRit YNo, CHN

28.0 ge ash prob sul (all thee) logh layg redent serm- ther is a lough enarel lager stach to perbe. XKF, XED, CHN

Probe Bukdaciach $=2503.6 \mathrm{~g}-\mathrm{g}$ imple

Cinbthothen ach $=1828.2 \mathrm{~g}$

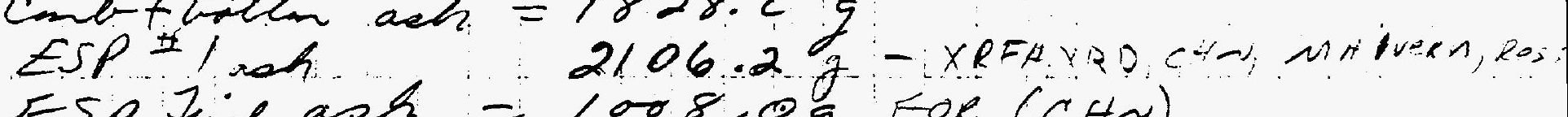

ESP tind ash = $1008.0 \mathrm{~g}$ EOR (CH )

Hrigutalth ast $=81.8 \mathrm{~g}$

sapplay Cychere $=59,6 \mathrm{~g} / \mathrm{CH}$

Flve gas pepy $=160.0 \mathrm{~g}$.

an conled Ax $=80.3 \mathrm{~g}$

Bypaso Eyclere bavie $=279.12$

No Twhe in shell h/on 2 ash

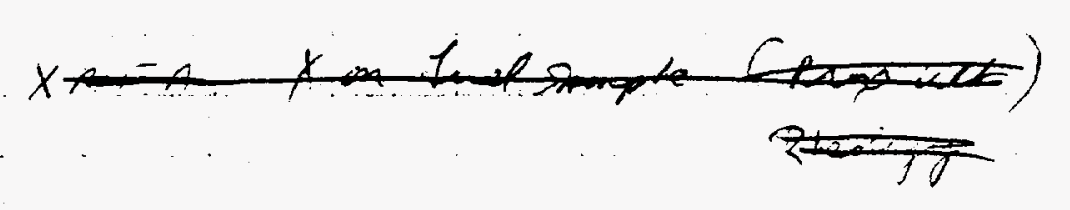

To Page No.

Witnessed \& Understood by me,

Date

Invented by

Date 
SYSTEM PRESSLRES

AFU/CWS/DSU Das Sheer IA

$\therefore \quad \therefore$ No. AF-CTS- 719 Date $3-11-97$ Acet No. 4874

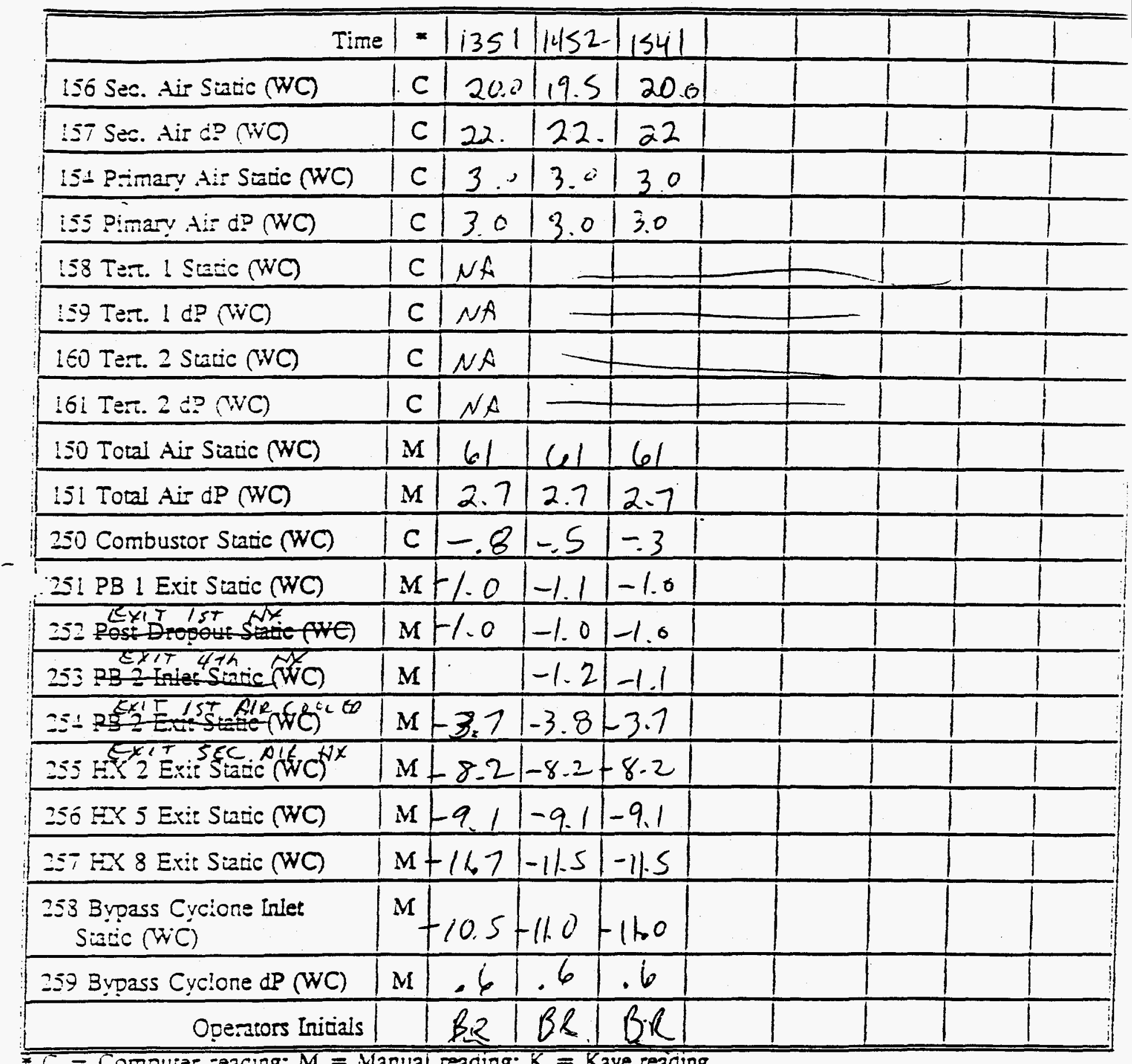

Page of 
SYSTEM PRESSURES CONL.

\section{AFU/CWS/DSU Dam Sheat $1 B$}

$\therefore \quad$ io. $A P-C T S-719$ Date 3-11-\$7 Aces No. 4874

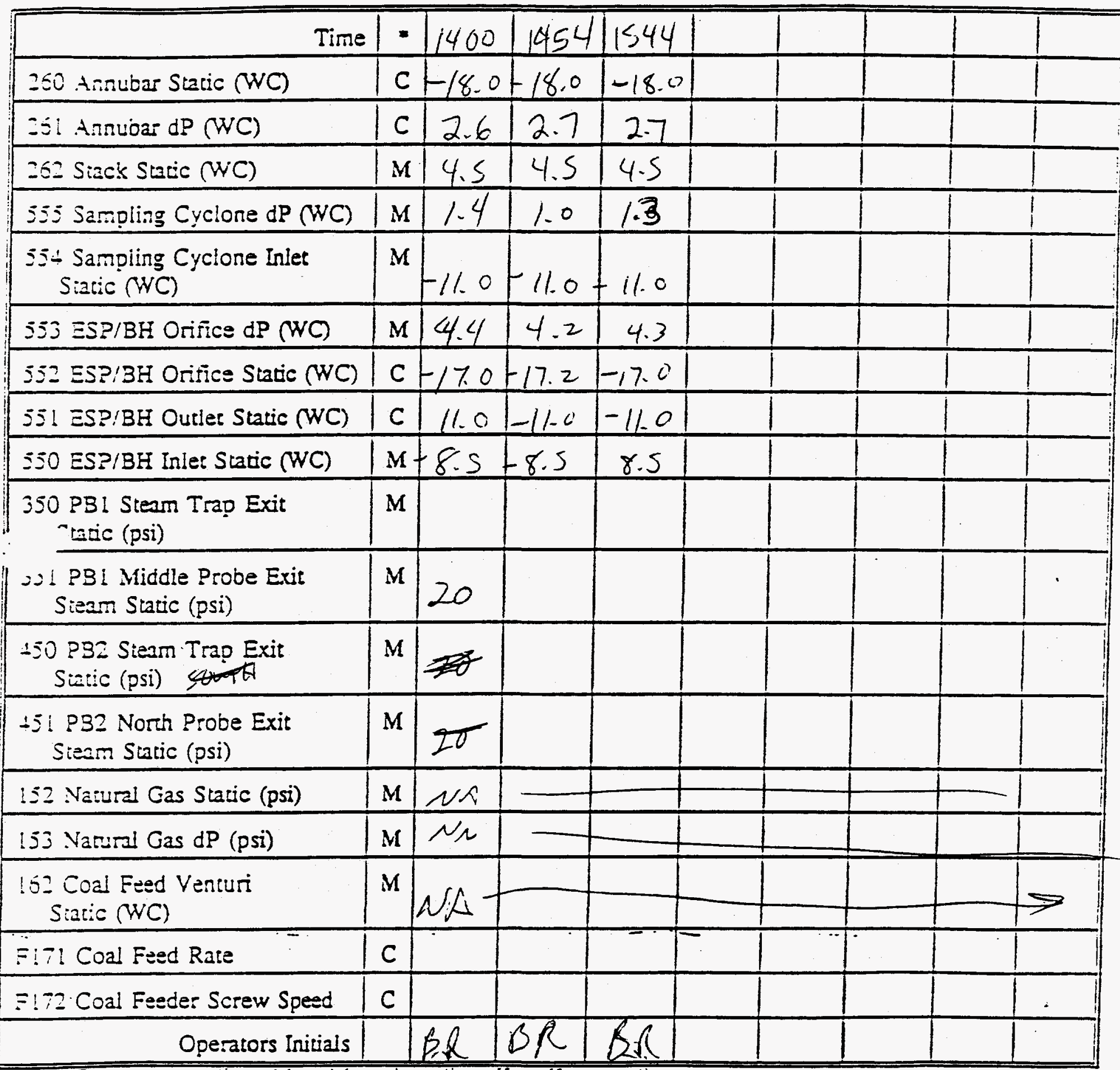

*C = Computer reacing; $M=M$ Manual reading; $K=$ Kaye reading

Page 1 of 
CTF Dae Snear 24

F... Vio. AF-CTS-719 Date $3-11-92$ Acon Nio. 4874

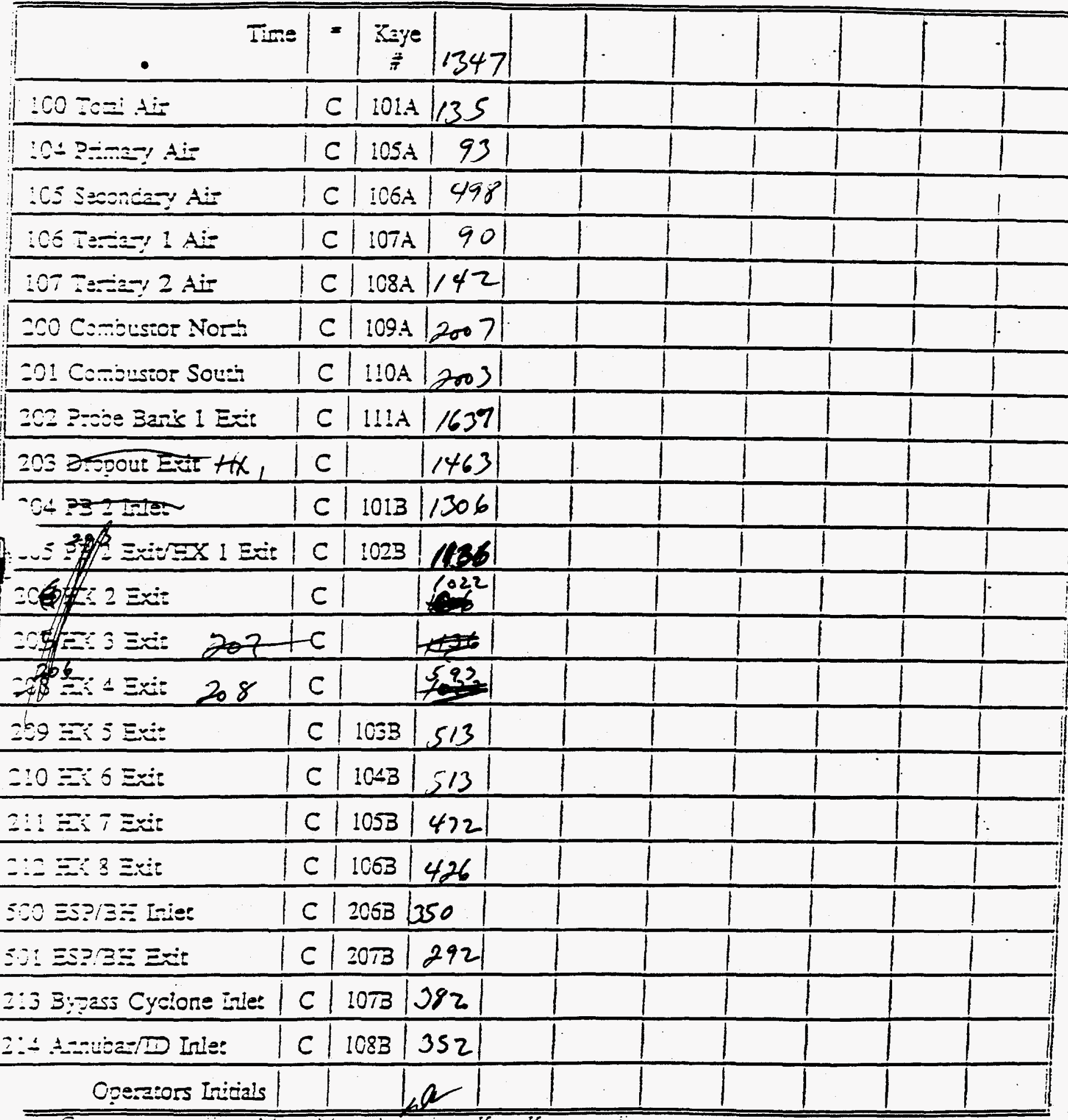

= Congu:e: racing; $M=$ MLnLa! recing; $K=$ Kaye reading as are Nones are

m 
Run No. AF-CTS-719 Date $3-11.97$ Acct. No. 4874

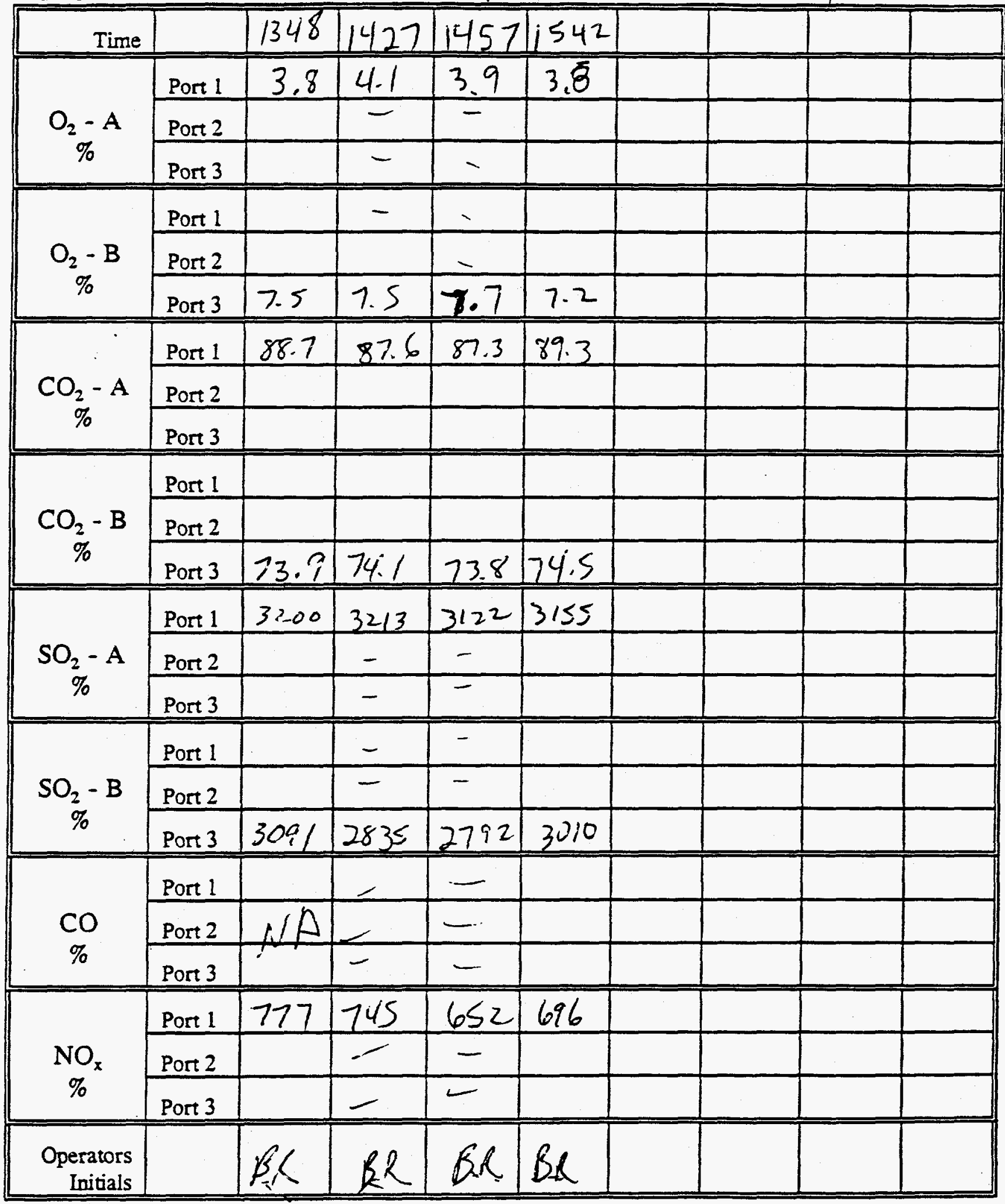

use a dash ( - ) for readings not required

$$
\text { So } 2 \text { vendigo }=1 / 2 \text { astuan }
$$


Form $611(8-85)$

COAL SLURRY

CWS Data Sheet 10

Run No. AF-CTS- 719 Date $3-11-97$ Acct. No. 4874 Slurry Trade Name Manufacturer \& Solids Slurry Nozzle Throat

Slurry Start Time Slurry Stop Time Total Slurry Burned

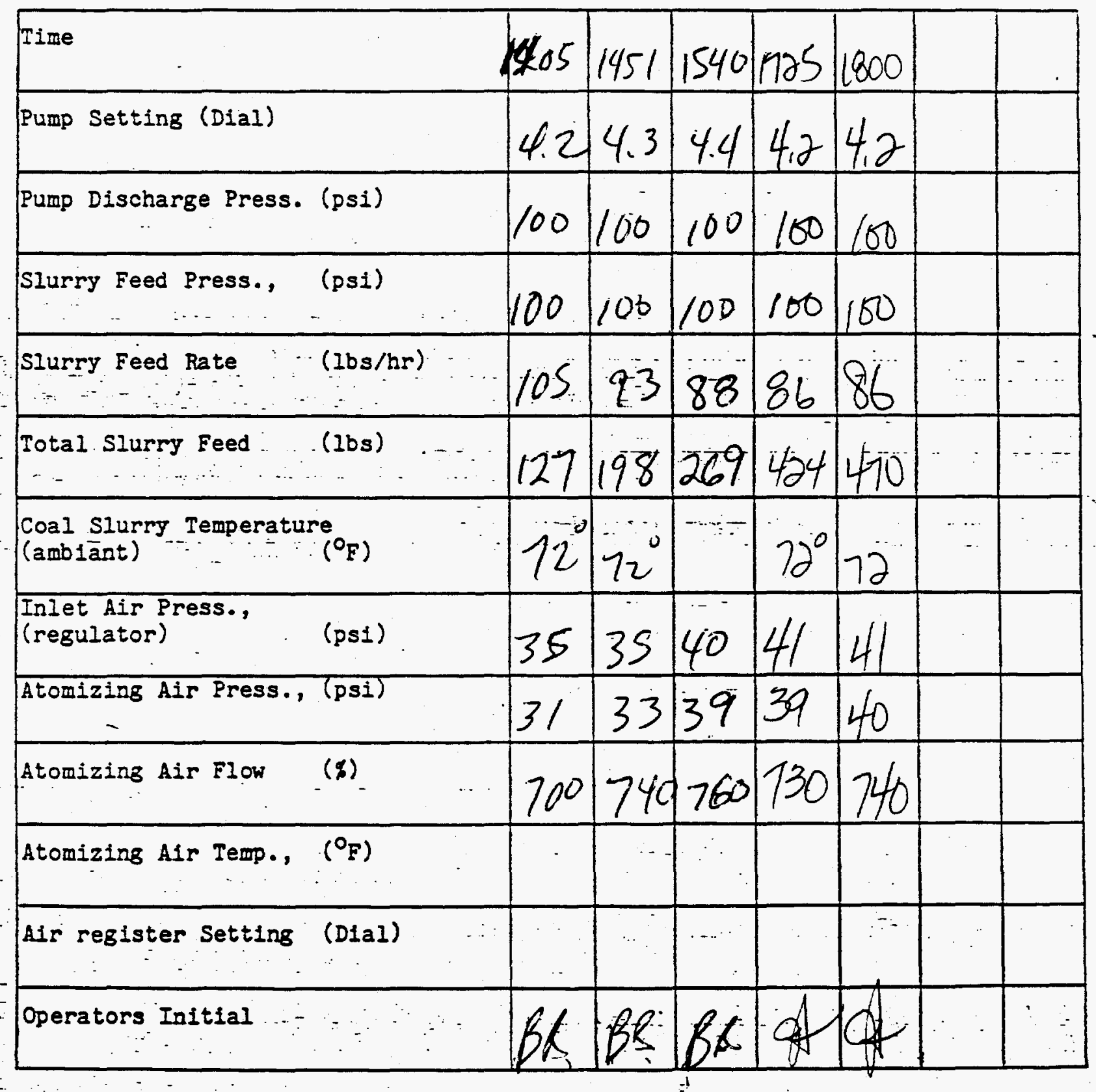

Page $l$ of 


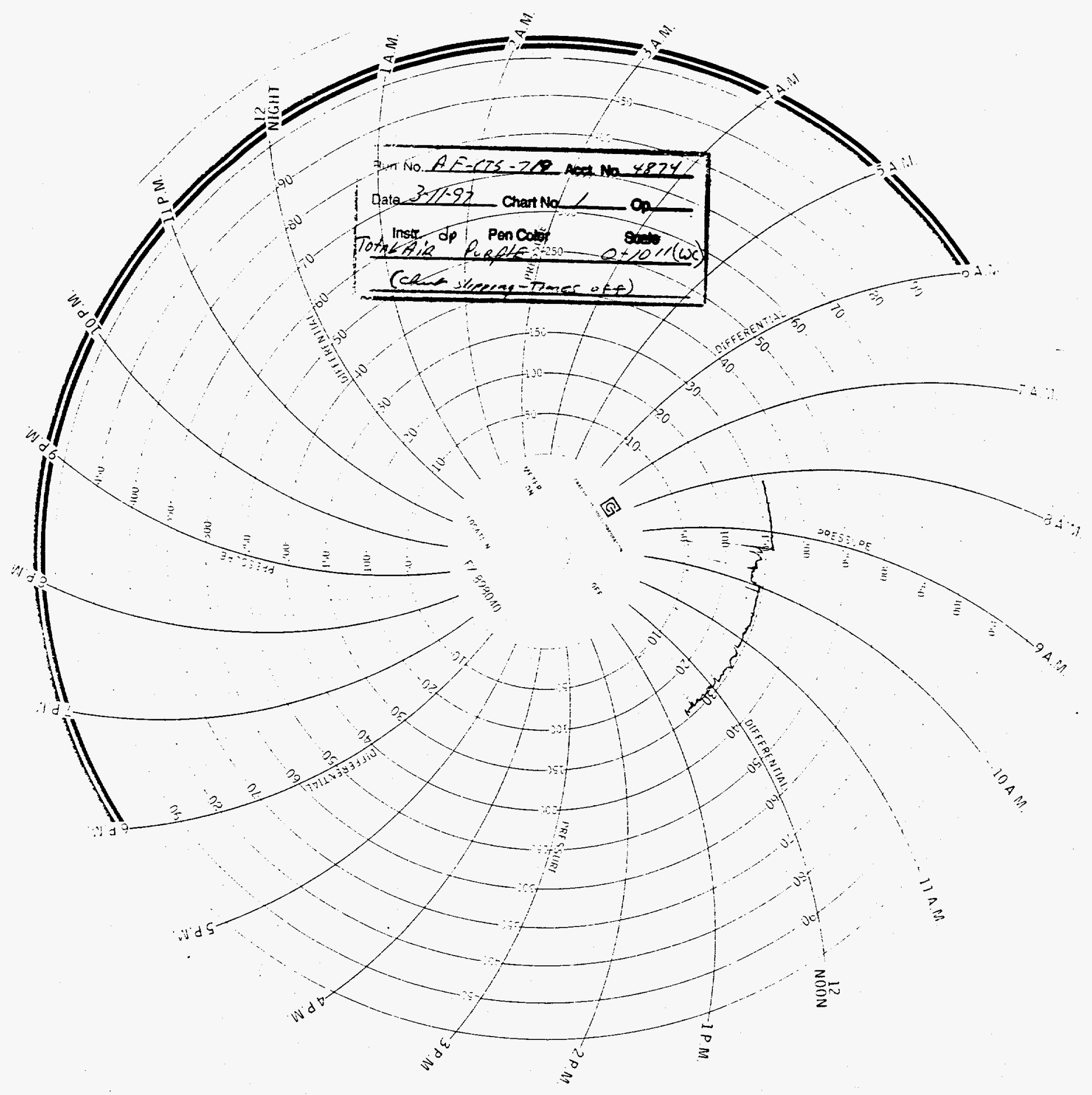




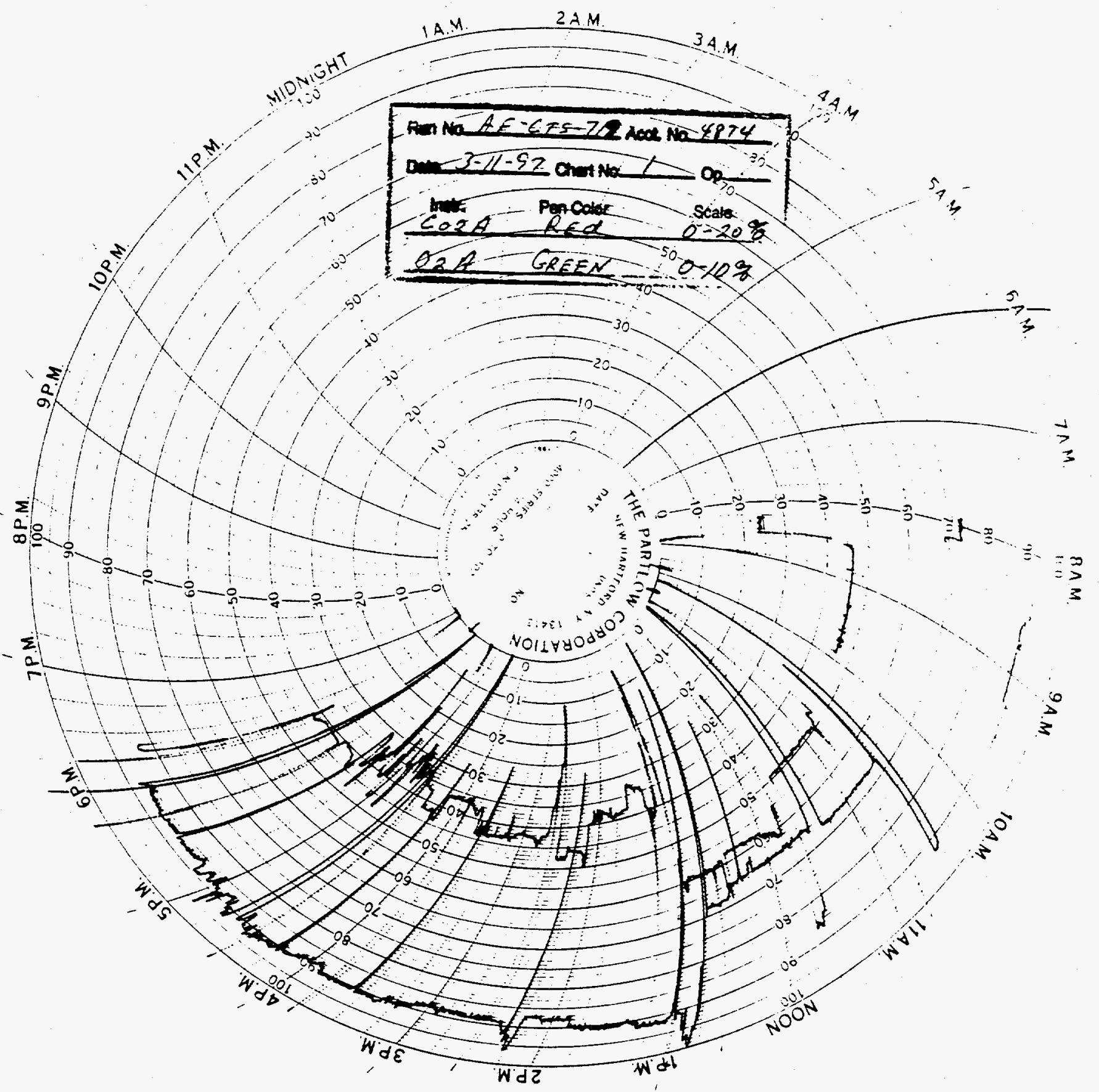




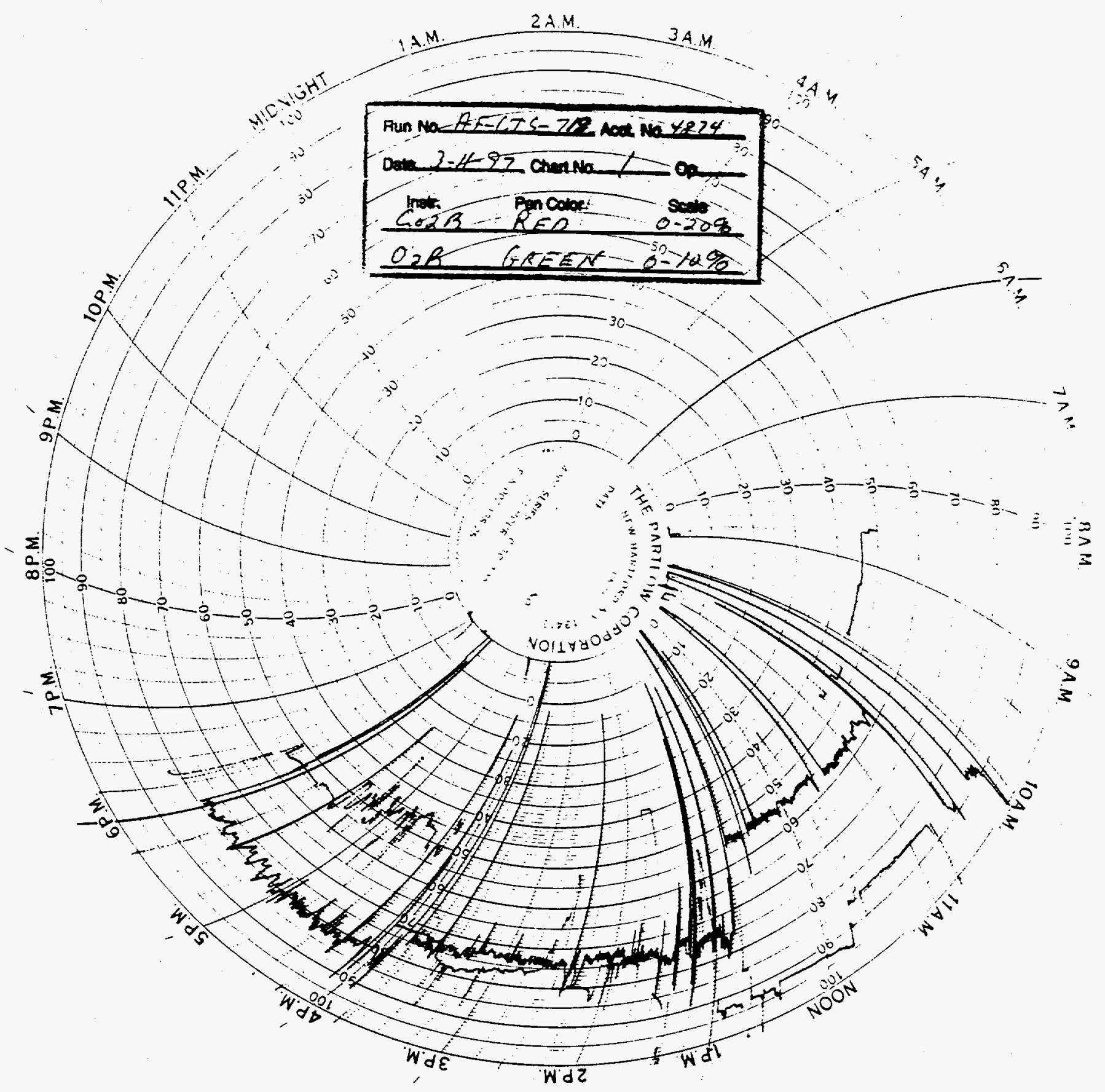




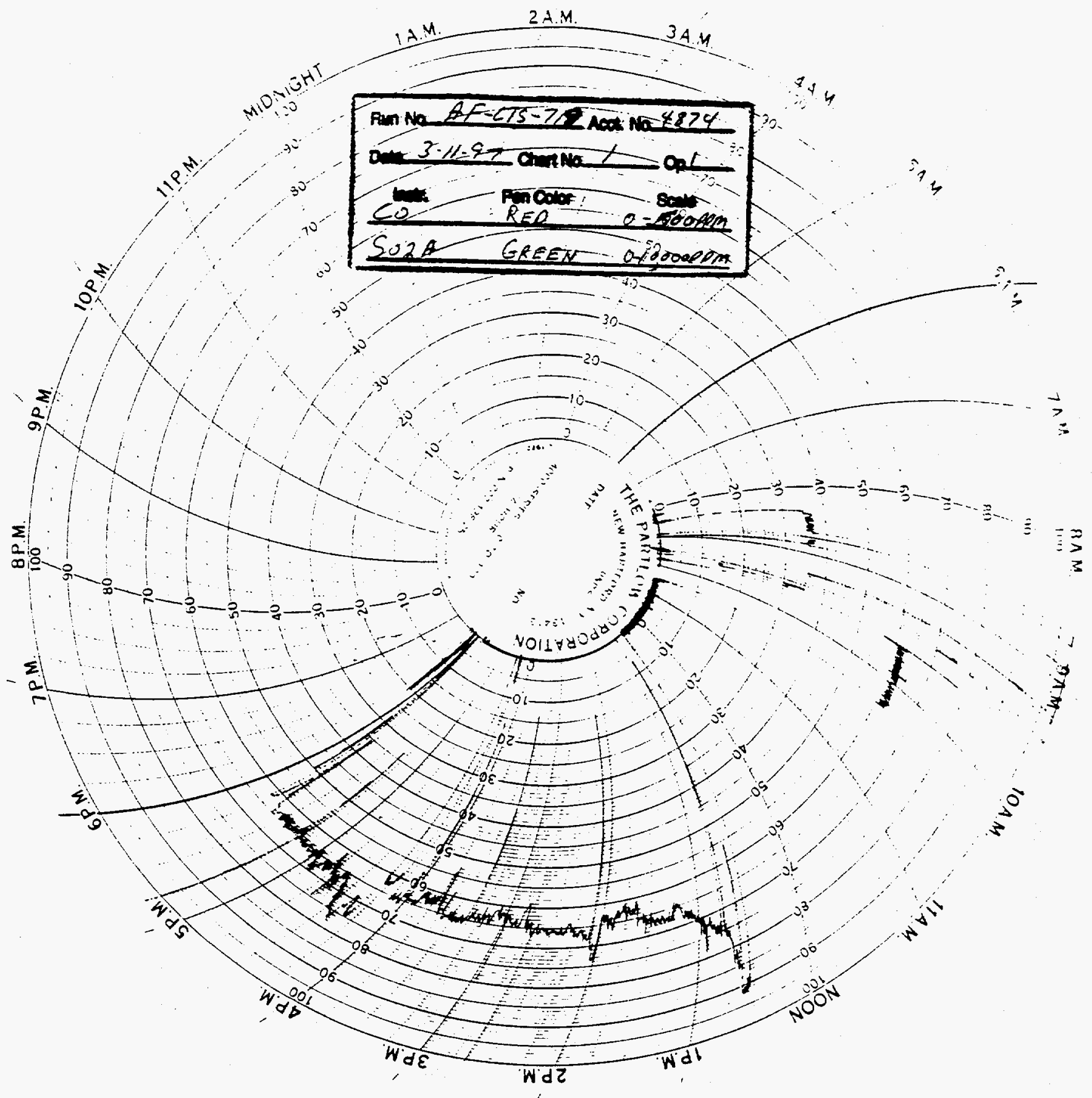




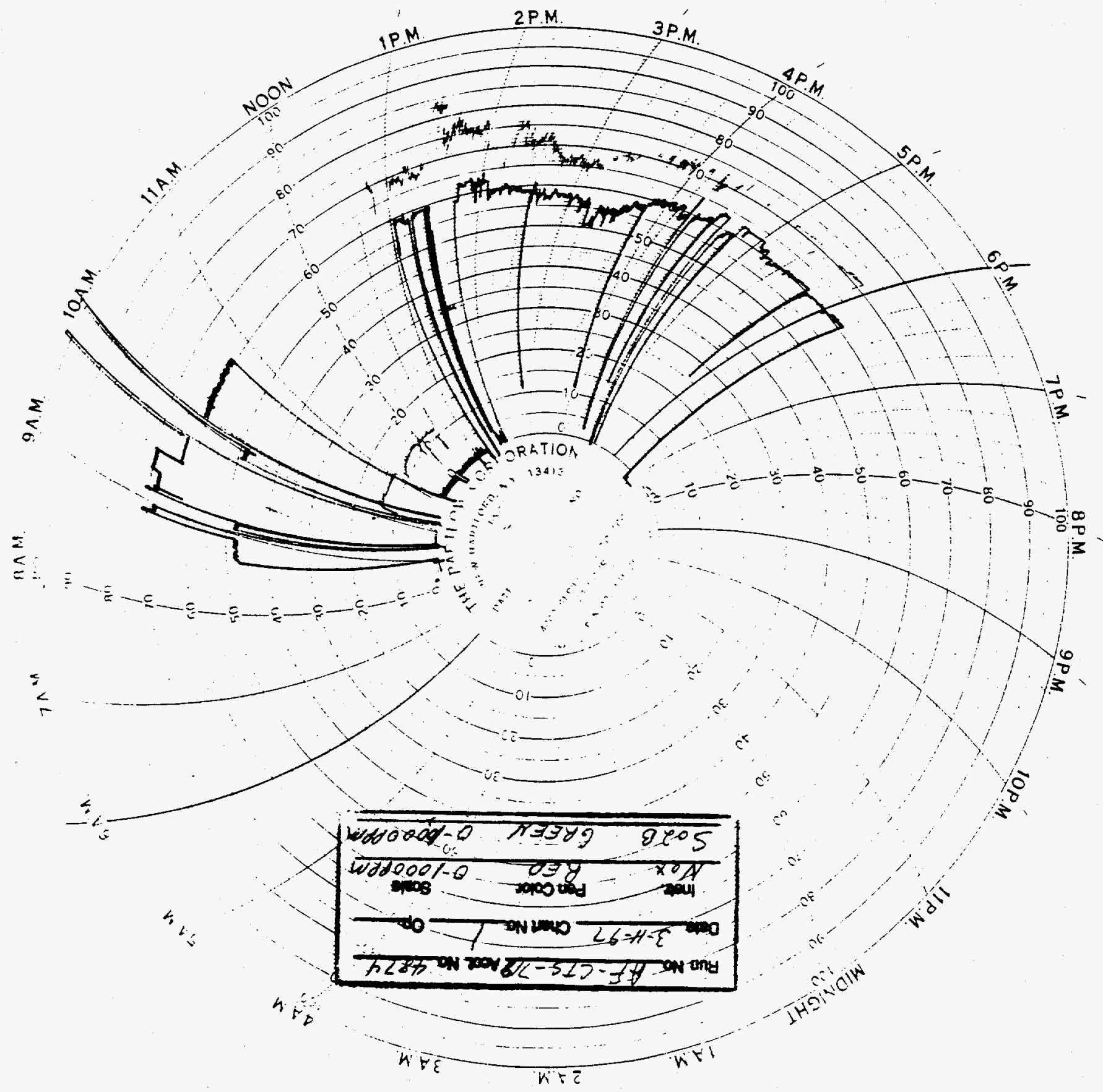




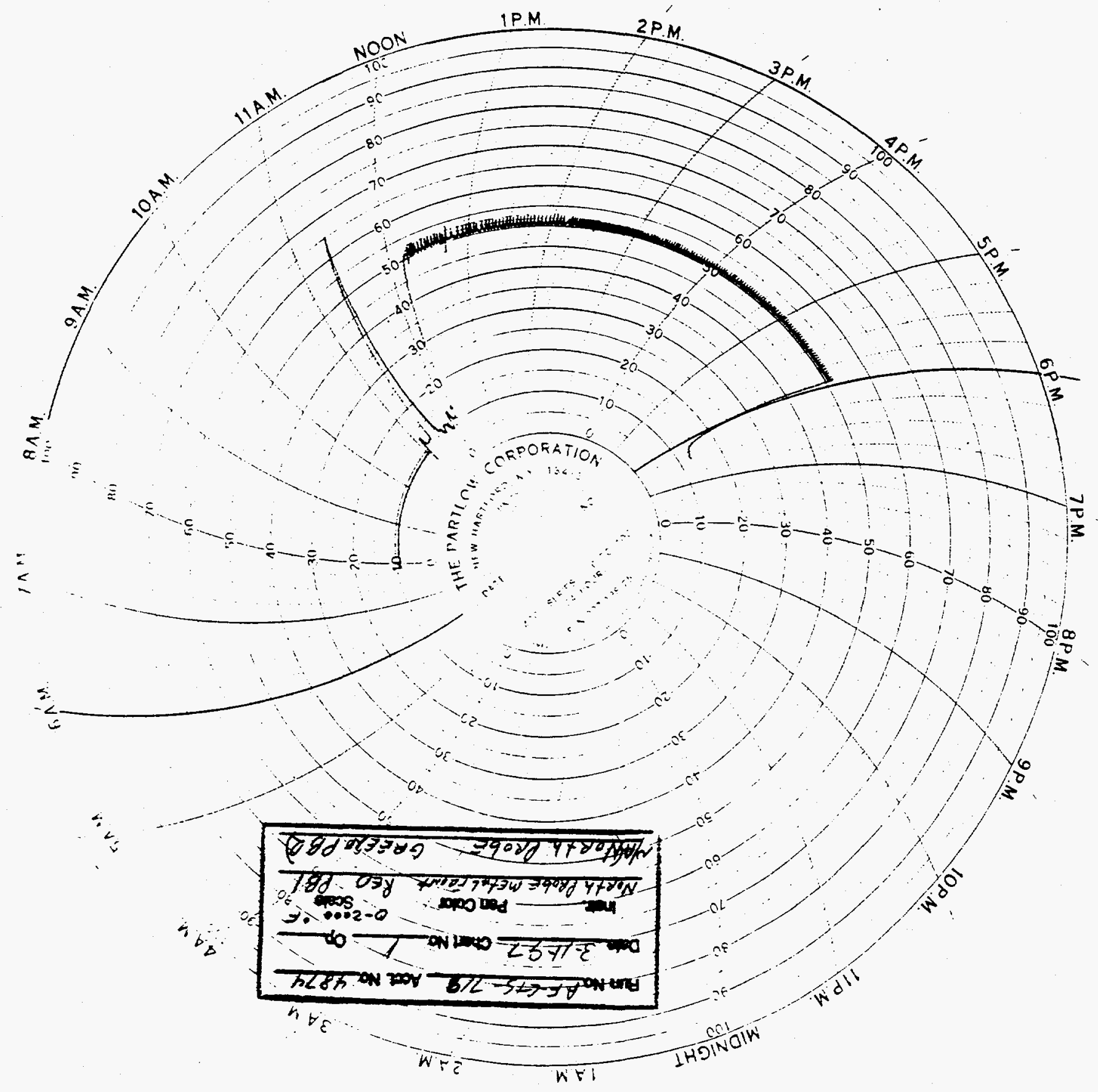




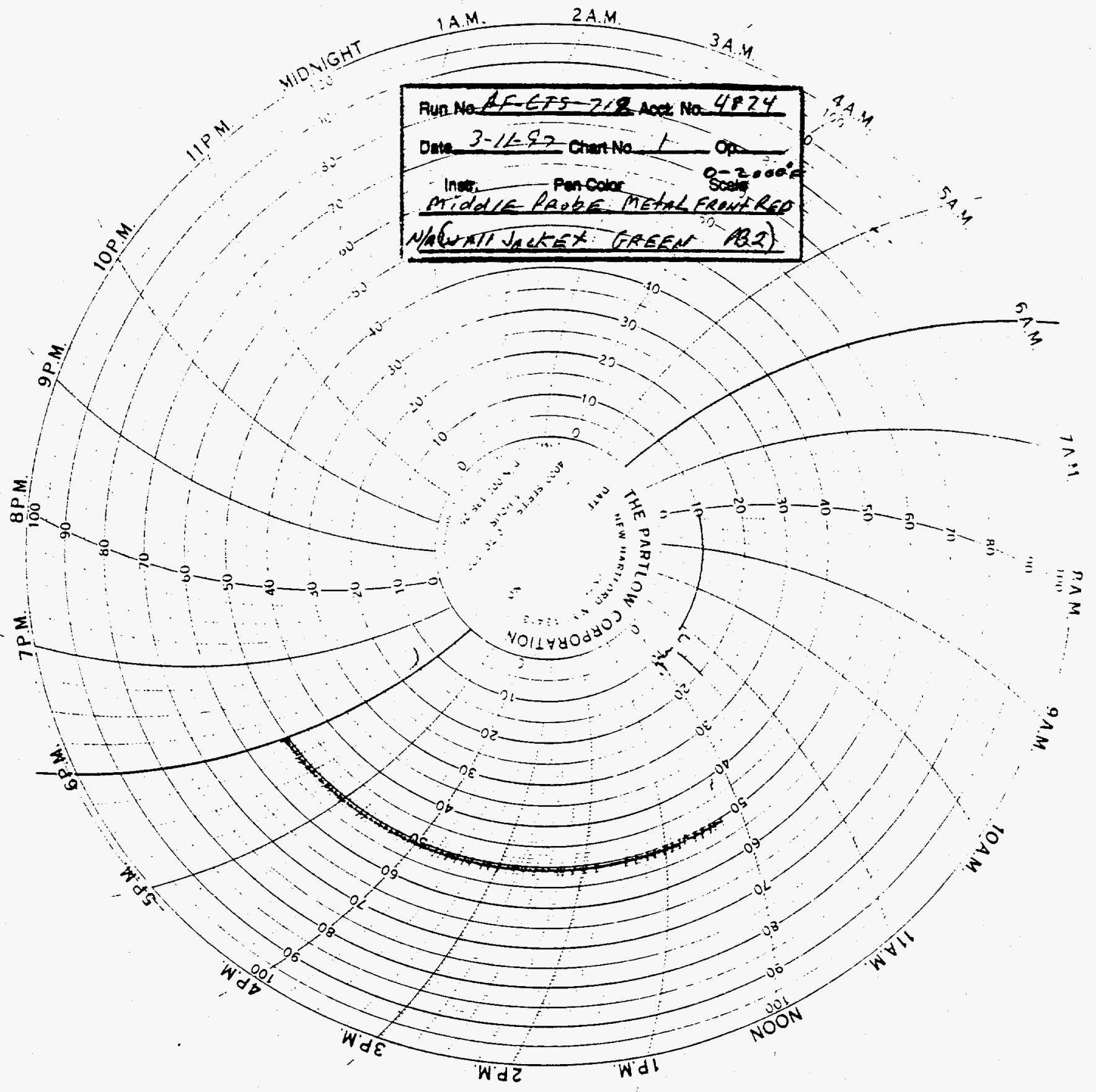




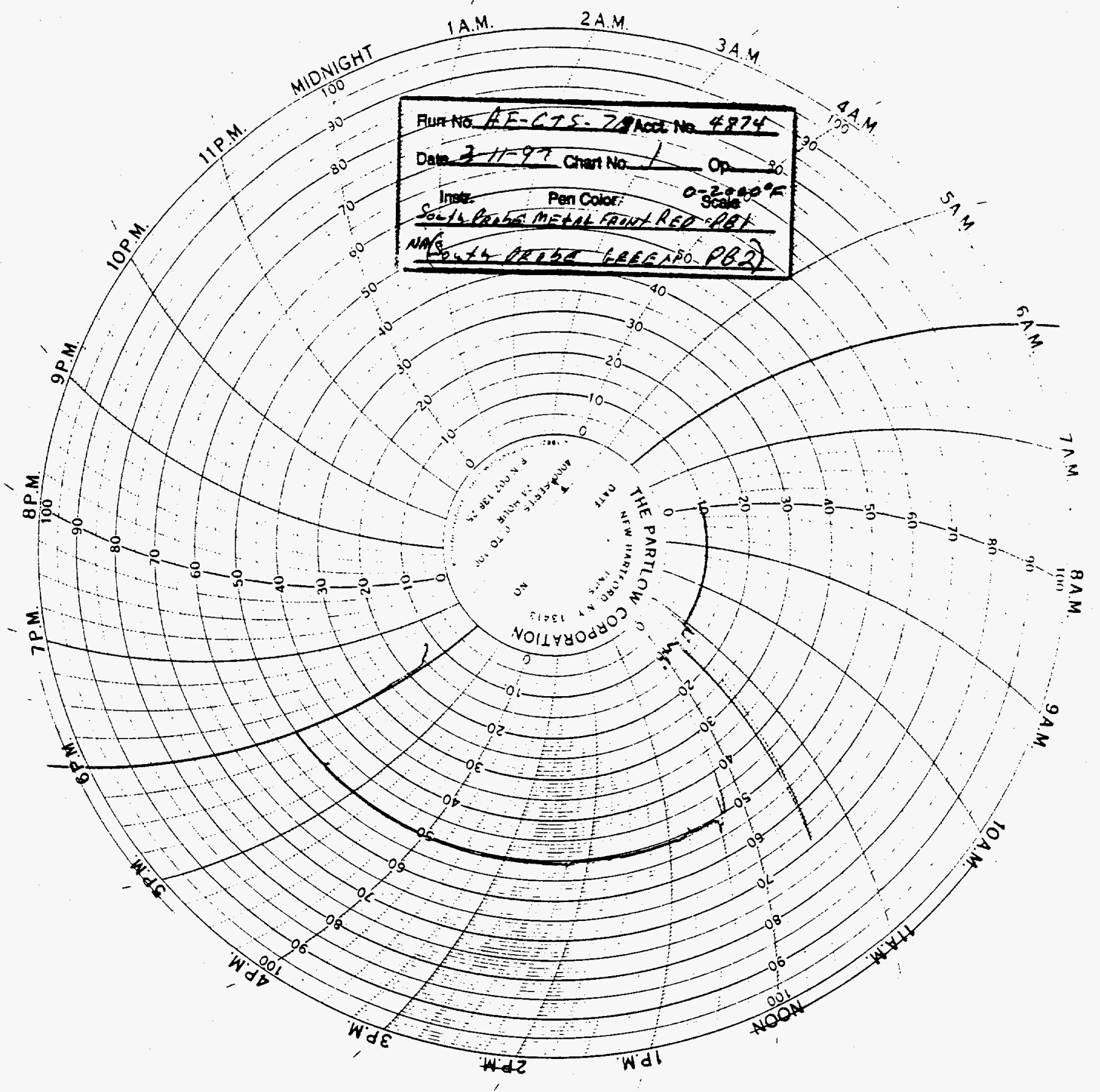

